\title{
Firm dynamics in the Dutch audit industry : an empirical investigation into longevity, exit and spinoff between 1880 and 1992
}

Citation for published version (APA):

Brocheler, V. K. (1999). Firm dynamics in the Dutch audit industry : an empirical investigation into longevity, exit and spinoff between 1880 and 1992. [Doctoral Thesis, Maastricht University]. Universiteit Maastricht. https://doi.org/10.26481/dis.19991217vb

Document status and date:

Published: 01/01/1999

DOI:

10.26481/dis.19991217vb

Document Version:

Publisher's PDF, also known as Version of record

Please check the document version of this publication:

- A submitted manuscript is the version of the article upon submission and before peer-review. There can be important differences between the submitted version and the official published version of record.

People interested in the research are advised to contact the author for the final version of the publication, or visit the DOI to the publisher's website.

- The final author version and the galley proof are versions of the publication after peer review.

- The final published version features the final layout of the paper including the volume, issue and page numbers.

Link to publication

\footnotetext{
General rights rights.

- You may freely distribute the URL identifying the publication in the public portal. please follow below link for the End User Agreement:

www.umlib.nl/taverne-license

Take down policy

If you believe that this document breaches copyright please contact us at:

repository@maastrichtuniversity.nl

providing details and we will investigate your claim.
}

Copyright and moral rights for the publications made accessible in the public portal are retained by the authors and/or other copyright owners and it is a condition of accessing publications that users recognise and abide by the legal requirements associated with these

- Users may download and print one copy of any publication from the public portal for the purpose of private study or research.

- You may not further distribute the material or use it for any profit-making activity or commercial gain

If the publication is distributed under the terms of Article 25fa of the Dutch Copyright Act, indicated by the "Taverne" license above, 


\section{FIRM DYNAMICS IN THE DUTCH AUDIT INDUSTRY}

An empirical investigation into longevity, exit and spinoff between 1880 and 1992 
ISBN: 90-9012992-8

(c) 1999, Vera Bröcheler

Cover design and photography: Hans Hoornstra 


\title{
FIRM DYNAMICS IN THE DUTCH AUDIT INDUSTRY
}

\author{
An empirical investigation into longevity, exit and spinoff \\ between 1880 and 1992
}

\section{PROEFSCHRIFT}

ter verkrijging van de graad van doctor aan de Universiteit Maastricht, op gezag van de Rector Magnificus, Prof. dr. A.C. Nieuwenhuijzen Kruseman, volgens het besluit van het College van Decanen, in het openbaar te verdedigen op vrijdag 17 december 1999 om 16.00 uur

door

Vera Katja Bröcheler 


\section{Promotores:}

Prof. dr. S.J. Maijoor

Prof. dr. A. van Witteloostuijn

\section{Beoordelingscommissie:}

Prof. dr. W.F.J. Buijink (voorzitter)

Dr. G.M. Duijsters (Technische Universiteit Eindhoven)

Prof. dr. F.C. Palm 


\section{ACKNOWLEDGEMENTS}

Papa,

Mama,

Rens,

Krit,

Stan,

Eugène Rebers,

Arjen van Witteloostuijn,

Steven Maijoor,

Christophe Boone,

Glenn Carroll,

Caren Schelleman, Annelies Hogenbirk,

Hans van Kranenburg,

Peter Berends,

Maureen Lankhuizen,

Bas Koene,

Chris de Neubourg,

Piety van der Nagel,

Carla van den Bos,

Geraldine van Leeuwen,

Inge Kozich,

Marlies Smits,

Dennis Breuker,

Hans Hoornstra,

Dames van het dinerclubje,

En collega's,

Bedankt!

Furthermore, financial support from the Limperg Institute for collecting a large part of the database is gratefully acknowledged. 


\section{CONTENTS}

\section{Acknowledgments}

1 Introduction 1

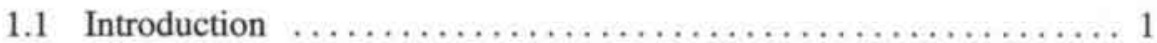

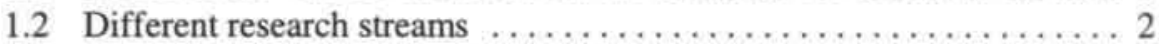

1.3 The reasons for selecting the Dutch audit market $\ldots \ldots \ldots \ldots \ldots . .$.

1.4 Purpose and research questions $\ldots \ldots \ldots \ldots \ldots \ldots \ldots \ldots \ldots \ldots$

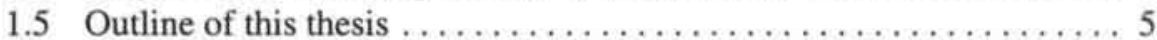

2 The Data 9

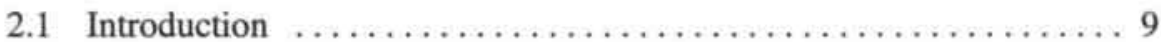

2.2 Evolution of the Dutch audit market in a nutshell $\ldots \ldots \ldots \ldots \ldots \ldots 9$

2.2.1 The first auditor $\ldots \ldots \ldots \ldots \ldots \ldots \ldots \ldots \ldots$

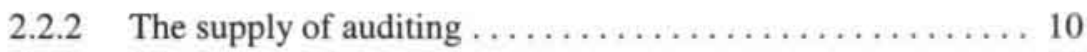

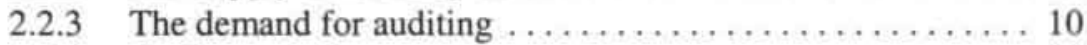

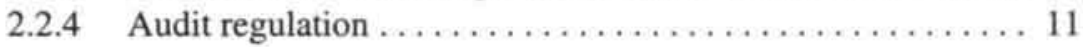

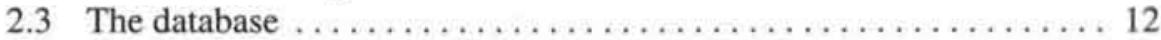

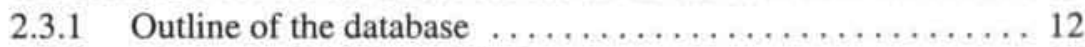

2.3.2 The method of data collection ................. 13

2.3.3 Completeness of the data ..................... 14

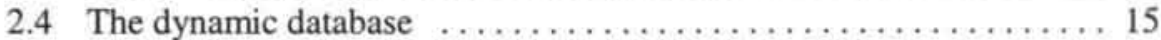

2.5 Descriptive statistics of the data $\ldots \ldots \ldots \ldots \ldots \ldots \ldots \ldots \ldots$

2.5 .1 Industry level statistics $\ldots \ldots \ldots \ldots \ldots \ldots \ldots \ldots \ldots \ldots$

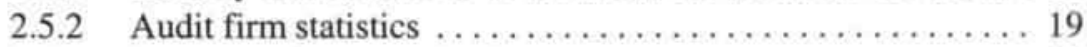

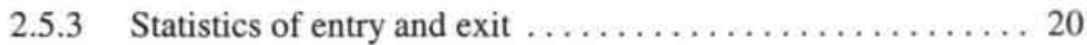

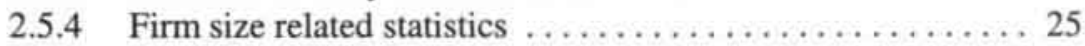

2.6 Summary . . . . . . . . . . . . . . . . . . . . . . 30

Appendix 2.1 Genealogy of Dutch auditors' associations between 1895-1992 .............................. 31

Appendix 2.2 Numerical overview of data sources over 1880-1992 . . . 32

Appendix 2.3 An estimate of the completeness of the research sample .. 33

Appendix 2.4 Size distribution of the Dutch audit market for approximately every 10 years $\ldots \ldots \ldots \ldots \ldots \ldots \ldots \ldots \ldots$ 


\section{CONTENTS}

3 Event History Analysis 39

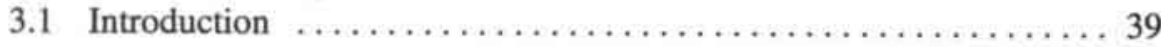

3.2 Basic model, technique and data structure $\ldots \ldots \ldots \ldots \ldots \ldots .40$

3.2.1 Basic model ........................... 40

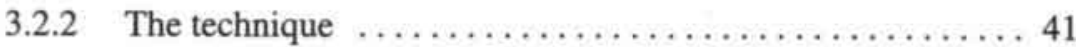

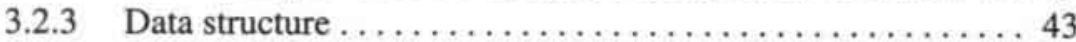

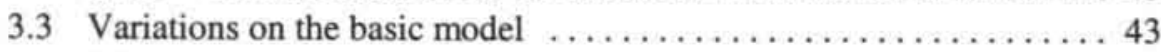

3.3.1 Discrete versus continuous $\ldots \ldots \ldots \ldots \ldots \ldots \ldots \ldots, 43$

3.3.2 Parametric versus non-parametric ................ 44

3.3.3 Multiple episodes ......................... 44

3.3.4 Multiple destinations ...................... 44

3.4 Different age dependency specifications $\ldots \ldots \ldots \ldots \ldots \ldots \ldots, 45$

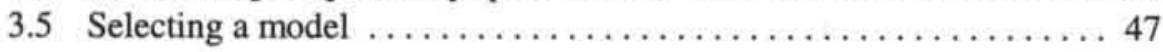

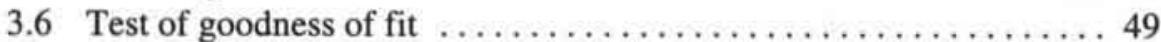

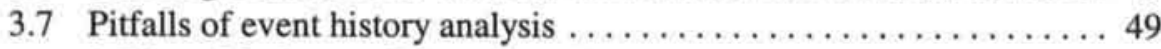

3.7.1 (Unobserved) heterogeneity ................... 49

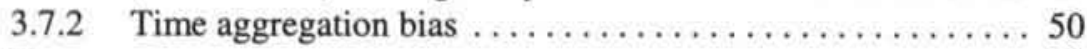

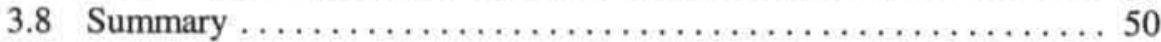

4 Auditor Human Capital and Audit Firm Survival 51

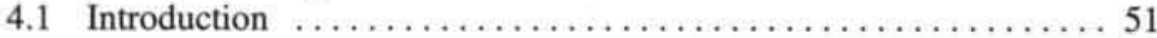

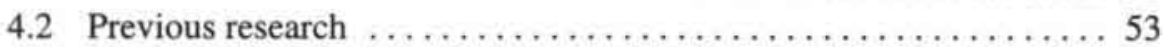

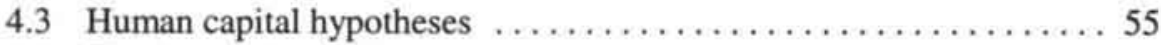

4.4 The data and variables under study $\ldots \ldots \ldots \ldots \ldots \ldots \ldots \ldots \ldots \ldots \ldots$

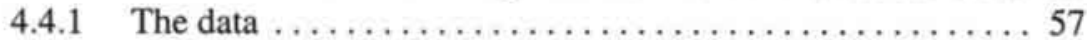

4.4 .2 Variables ................................. 58

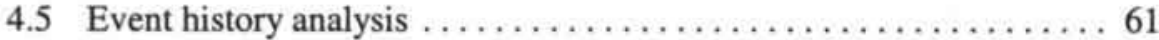

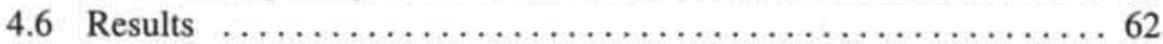

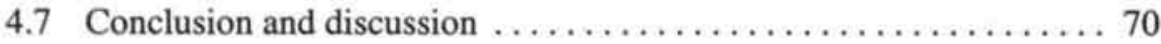

5 Resource Partitioning Processes and Audit Firm Survival 75

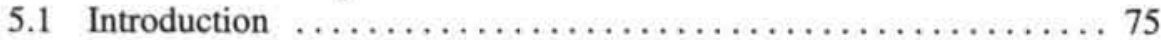

5.2 Resource partitioning: theory and evidence $\ldots \ldots \ldots \ldots \ldots \ldots, 77$

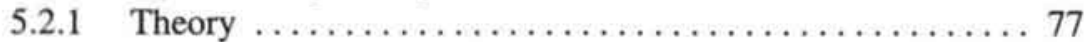

5.2 .2 Evidence .............................. 79

5.3 Resource partitioning among professional service organizations $\ldots 80$

5.3 .1 Theory and hypothesis $\ldots \ldots \ldots \ldots \ldots \ldots \ldots \ldots \ldots$

5.3 .2 Objections to the theory and hypothesis $\ldots \ldots \ldots \ldots \ldots .65$ 
5.3.3 Influence of the laws within the profession $\ldots \ldots \ldots \ldots 85$

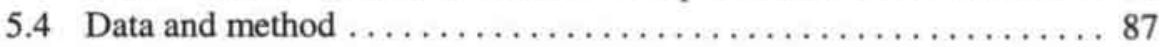

5.4.1 Data sources and coding rules ................. 87

5.4 .2 Variables and measurement $\ldots \ldots \ldots \ldots \ldots \ldots \ldots \ldots$

5.4 .3 The model $\ldots \ldots \ldots \ldots \ldots \ldots \ldots \ldots \ldots \ldots \ldots \ldots \ldots$

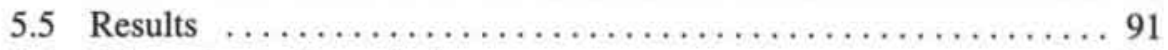

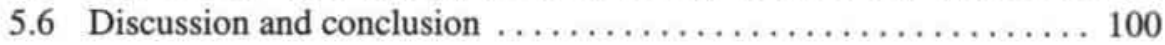

6 Push and Pull Factors as Determinants of Spinoffs in the Audit $\begin{array}{ll}\text { Industry } & 103\end{array}$

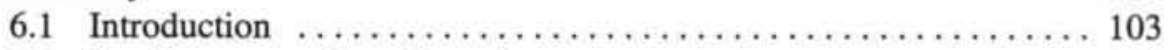

6.2 Previous research and hypotheses $\ldots \ldots \ldots \ldots \ldots \ldots \ldots \ldots \ldots \ldots \ldots \ldots \ldots$

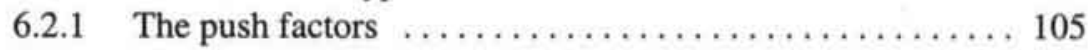

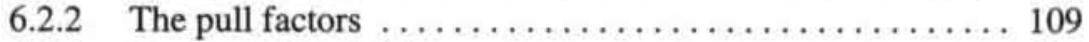

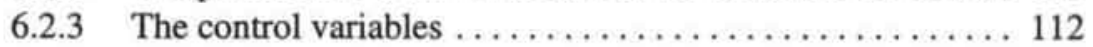

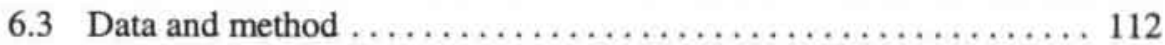

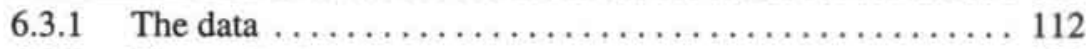

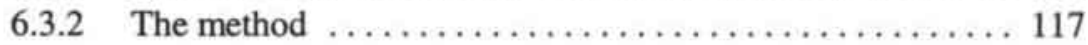

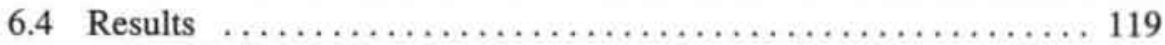

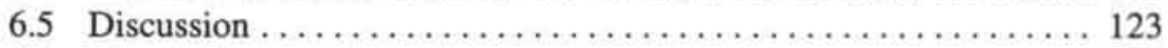

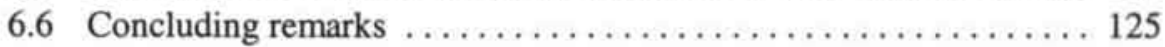

7 Appraisal 127

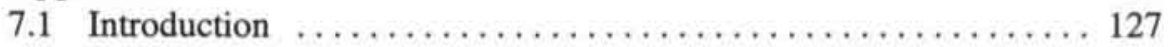

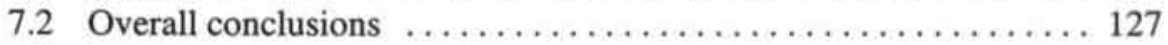

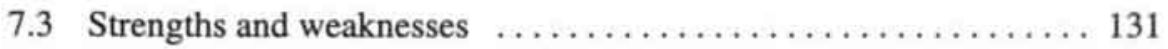

7.4 Suggestions for further research $\ldots \ldots \ldots \ldots \ldots \ldots \ldots \ldots \ldots \ldots \ldots \ldots \ldots$

7.4.1 Suggestions that elaborate on the research issues of this thesis ................................ 133

7.4.2 Suggestions that explore other long-term firm dynamics ... 135

7.4.3 Suggestions that go into non-firm dynamics research $\ldots \ldots 135$

$\begin{array}{ll}\text { References } & 137\end{array}$

$\begin{array}{lr}\text { Nederlandse Samenvatting } & 145\end{array}$

$\begin{array}{lr}\text { Curriculum Vitae } & 149\end{array}$ 



\section{Chapter 1}

\section{INTRODUCTION}

\subsection{Introduction}

This thesis studies firm dynamics. For this purpose two characteristics of the firm are important. First, the firm is an entity that belongs to a market or an industry. Second, the firm has a life, with birth, all kinds of changes and death. Questions related to the lives and the causes of changes in the lives of firms are, for example: Why are firms born? What events or factors affect firms during their lives? What causes changes in a firm's life? And finally, why do firms die? Questions such as these lead one to search for the reasons behind firm dynamics. These firm dynamics, and their causes, are the subject of this thesis. The general research question guiding this thesis is then: Which factors explain the long-term dynamics of firms within an industry - more specifically longevity, exit and spinoff? To seek answers to this question, this thesis is mainly empirical in nature. For the empirical analyses we chose to follow Dutch audit firms during their lives: more specifically, the complete Dutch audit market from its first existence in 1880 until 1992 is investigated.

In studying the subject, this thesis uses and combines insights from market structure research from both organization and audit research traditions. Both organization and audit research traditions already have devoted considerable effort to studying (audit) markets, but integrating insights from these fields of research has not been done until recently (Boone and van Witteloostuijn, 1995; Buijink et al., 1995; Maijoor et al., 1995; Maijoor and van Witteloostuijn, 1996; Pennings et al., 1998). The different research streams do not address the same issues with respect to (audit) markets, nor do they exploit the same methodologies. Thus, their integration and application to firm dynamics can provide new insights for both fields of study.

The remainder of this chapter is structured as follows. Section 1.2 describes the different streams of research relevant to the subject of firm dynamics in this thesis. Subsequently, Section 1.3 justifies why the Dutch audit market is the selected market to study in this thesis. Then, Section 1.4 discusses the purpose of this thesis, and states the general and specific research questions. Finally, Section 1.5 provides an outline of the remainder of this thesis. 


\subsection{Different research streams}

In trying to explain firm dynamics, this thesis makes use of market study theories. Market studies try to explain the market structure of (and the market dynamics within) an industry. This can be done at two different levels and from two different angles: the focus can be on the industry or on the firm, and the study can be static or dynamic. As mentioned in the introduction, we combine market studies from both organization and audit research traditions. Within organization sciences, two important streams, originating from different fields, regarding market structure can be distinguished. Within economics-based organization sciences this is industrial organization, and within sociology-based organization sciences this is organizational ecology. Both traditions share an interest in explaining the ups and downs in the history of industries and organizations (Boone and van Witteloostuijn, 1995). Within auditing research, the market structure issue has also received increasing attention, leading to a tradition of audit market research. Summarizing, this thesis uses three different research streams, i.e., industrial organization, organizational ecology and audit market research.

First, industrial organization mainly focuses on how market processes influence firm behavior, and what the latter's influence is on performance (Schmalensee and Willig, 1989; Scherer and Ross, 1990). Furthermore, much attention is paid to size distributions and concentration ratios. Sutton (1992), for example, tries to explain the concentration ratio with the concept of sunk costs, and as a result a minimum required scale in production. Another interest of industrial organization lies in the evolution of markets. Here, the concept of a dual market, defined as a market with both many firms and a high concentration ratio, has received considerable attention. The evolution of the Dutch audit industry is a clear example of such a dual market structure (Boone and van Witteloostuijn, 1995). Research in industrial organization focuses mainly on the industry level, and is both theoretical and empirical in nature. Moreover, the interest in market structures is both dynamic and static.

Second, organizational ecology focuses mainly on density (the number of firms within an industry) and the development of organizational forms (Boone and van Witteloostuijn, 1995). An interesting parallel with industrial organization's dual market structure is the resource partitioning theory within organizational ecology (Carroll, 1985; Carroll and Hannan, 1995; Boone and van Witteloostuijn, 1996). Resource partitioning theory addresses the relationship between an increasing market concentration, and the founding and survival of small specialist organizations. The rationale behind this theory is that as several firms grow big, a niche for small specialist firms will appear in the market, increasing their founding and survival chances. Research in organizational ecology is mainly empirical, focusing on the dynamic relations (i.e., 
relations through time), both at industry and firm level. ${ }^{1}$

Third and finally, audit market research describes the structure of the audit market and the influence of this structure on other variables. In particular, the focus is mainly on the influence of audit market structure on the industry's competition, audit fees and audit quality (see Yardley et al., 1992). Until now, only a few studies have examined audit firm performance and survival, and this basically in an implicit way. This research stream is primarily empirical, including mainly traditional economic insights. Furthermore, it is mainly static, both at the industry and firm level.

\subsection{The reasons for selecting the Dutch audit market}

There are six main reasons for selecting the Dutch audit industry to investigate and test firm dynamics.

1. In the Netherlands, the audit market is well-documented (Maijoor et al., 1995). Since the early history of Dutch auditing, professional organizations have published membership lists which give detailed information on members and their audit firms. Therefore, the entire evolution of the industry can be investigated.

2. There is a need for additional studies of service industries. The audit industry is such a service industry, which implies that human capital is the most important production factor. Therefore, the data on the individual auditors (see reason 1), can give a good proxy of the size, success and failure of audit firms (Maijoor $e t$ al., 1995).

3. There are no real substitutes ${ }^{2}$ for audit services. The audit industry can thus be regarded as the entire market for this product, which makes interpreting the results easier.

4. The audit industry, with its development towards a dual market structure, characterized by many relatively small firms serving the niches in the market and a few relatively large firms serving the core-business in the market, is an interesting market from a theoretical point of view (see, e.g., Maijoor and van Witteloostuijn, 1996). It is interesting because two types of market structure co-exist: for the small

1 See for an in-depth treatment of the industrial organization - organizational ecology interface, van Witteloostuijn, Boone and Carroll (1999).

2 One could argue that the Board of Outside Directors or Supervisory Board also monitors the firm. However, this is not a substitute for an auditor who audits the firm and provides an audit statement. The function of the auditor is to provide a statement as an independent person. This is not the case for the Board of Outside Directors or Supervisory Board. Buijink (1992) found that the functions of the Board of Outside Directors or Supervisory Board and the auditor are in fact complementary. 
firm niche there is a market with many suppliers, and for the large firm segment there is a market with only a few suppliers.

5. Research on the history of audit firms and audit markets is relevant for the formulation of audit market policy and its likely impact on audit market functioning (Previts et al., 1990). In this sense, research on audit markets has practical relevance.

6. Historical accounting and auditing research has been limited to practices in AngloSaxon countries (Parker, 1993). The Dutch audit market is an example of an audit market that is just recently beginning to be explored. So, this study is an elaboration of recent Dutch research on audit markets (Boone and van Witteloostuijn, 1995; Buijink et al., 1995; Maijoor et al., 1995; Boone and van Witteloostuijn, 1996; Maijoor and van Witteloostuijn, 1996; Pennings et al., 1998).

\subsection{Purpose and research questions}

The purpose of this thesis is to gain better insight into the dynamics of firms in general and in (Dutch) audit firms in particular. To achieve this, the main research question is: Which factors explain the long-term dynamics of firms within an industry-more specifically longevity, exit and spinoff?

This thesis focuses on the audit market. In particular, the Dutch audit market between 1880, the year the first audit firm in the Netherlands was established, and 1992 is considered. More specifically, through a study of firm dynamics, the purpose of this thesis is to provide an overall picture of the variables that determine firm longevity and exit, by studying both market and firm characteristics. Particularly, this thesis not only considers more general market and firm explanations such as density, entry, age and size of the firm, but it focuses also on one of the most important firm variables in a service sector, i.e., human capital. Furthermore, it focuses on the interaction of market concentration and the size of the firm. In this way, it also pays attention to the large group of relatively small audit firms present in the Dutch audit market. Given the importance of these firms for job and wealth creation, research about small firms' success and survival is valuable (Carter et al., 1994). Moreover, this thesis tries to provide explanations for spinoffs, which are an important phenomenon in the audit industry. Finally, to study firm dynamics, emphasis is given to the method of analysis that is, the way questions about firm dynamics are examined best (i.e., event history analysis). Thus, the main research question can be divided into four more specific research questions:

1) How does human capital influence the survival chances of firms within the market?

2) How does the interaction between market concentration and firm size influence the survival chances of firms within the market? 
3) How do market and firm characteristics influence the chances of a firm having a spinoff?

4) How can event history analysis be helpful in providing better insight into the dynamics of firms?

The main contributions of this thesis are that it integrates a number of relevant theories regarding firm dynamics and that it studies these dynamics empirically. Until now, the studies on survival and exit within industrial organization have been both theoretical and empirical in nature. Studies in audit market research and organizational ecology are primarily empirical. However, with respect to organizational ecology, a cry for increased theoretical precision has emerged (Boone and van Witteloostuijn, 1999). Therefore, combining the theories from these streams of research, and testing the resulting hypotheses empirically, can provide a more general understanding of the functioning of firms within their markets. Figure 1.1 depicts a comparison of the different streams regarding market structures, as well as the focus of this thesis. Figure 1.2 provides an overview of the research questions central to this thesis, as well as the links between these research questions.

\subsection{Outline of this thesis}

The main body of this thesis consists of two descriptive chapters ( 2 and 3 ) and three empirical chapters $(4,5$ and 6$)$.

Chapter 2 describes the data that are collected. First, it elaborates on the Dutch audit market, and its history is briefly explained. Second, the method of data collection is introduced. Third, the construction of the dynamic database is explained. Fourth, the descriptive statistics are given, whereby a distinction is made between industry level statistics, audit firm statistics, statistics about entry and exit, and size related statistics of audit firms.

Chapter 3 relates to the last research question. It explains the empirical method used in this thesis (see Figure 1.1), presenting first the arguments for the choice for event history analysis. This method of analysis is then explained, and the characteristics of the most common models, as used in the next three empirical chapters, are considered. Finally, attention is given to the most appropriate test of goodness of fit, and the pitfalls of event history analysis.

The first empirical chapter, Chapter 4, is related to the first research question. It considers the influence of human capital variables on the survival chances and on 
Figure 1.1: The different streams of marke structure research, as well as the focus of this thesis ${ }^{3}$

Industry level
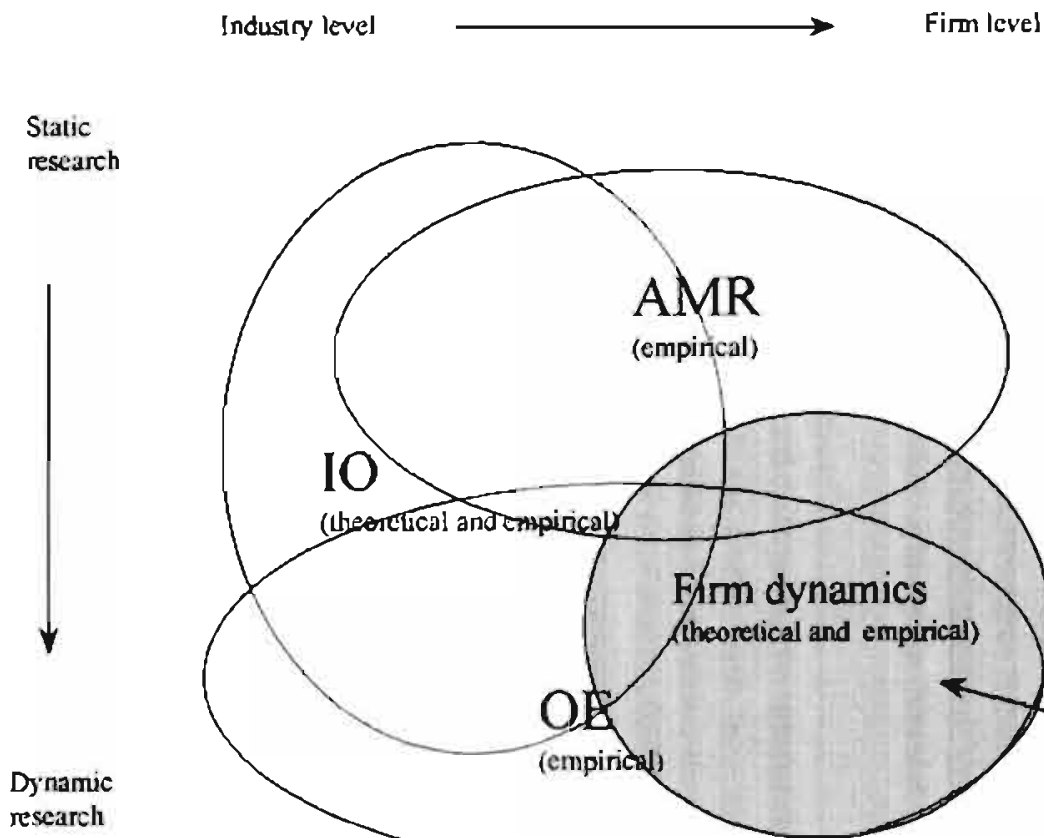

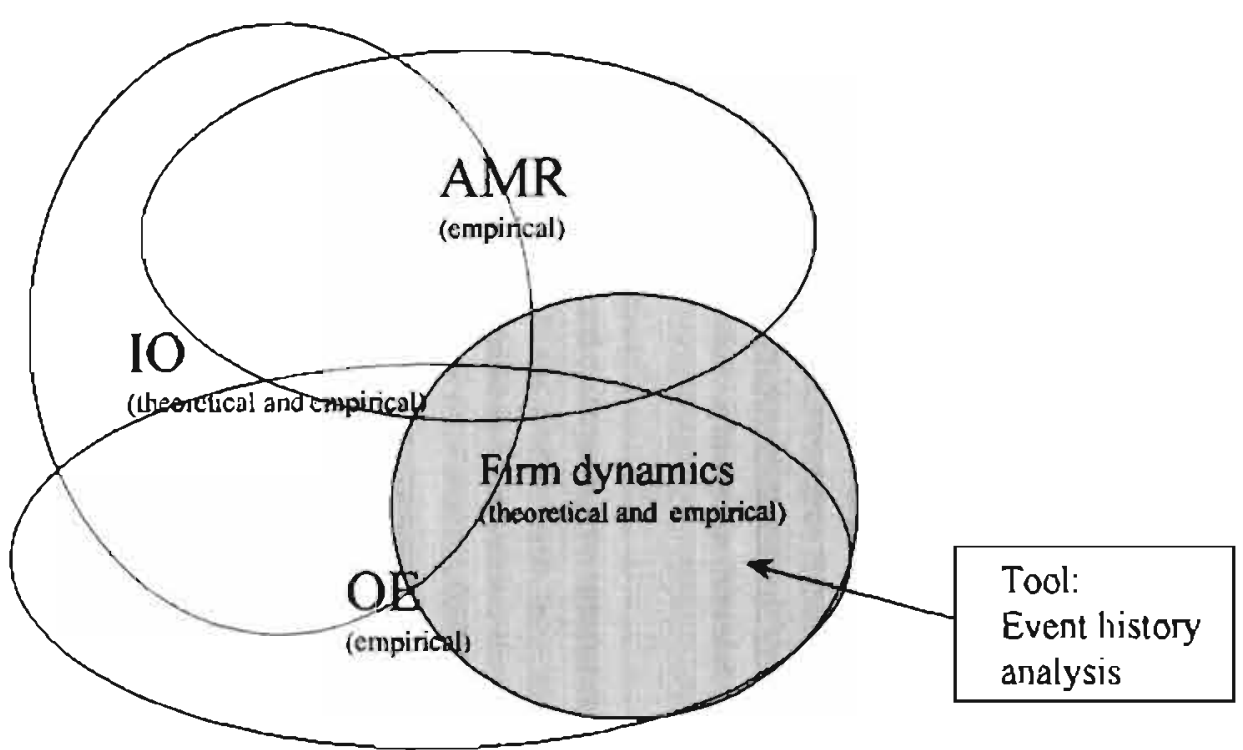

Note: $I O=$ industrial organization, $O E=$ onganizational ecology, and $A M R$ = audit market research.

3 This figure is not all-embracing. However, it provides an indication of the relationships between the different fields of research considered in this thesis. 
Figure 1.2: An overview of the subjects covered in this thesis

\section{Firm dynamics}

Time: $\quad:=0 \quad l=J \quad l=2$

$1=n$

$\mathrm{I}=\mathrm{s}$

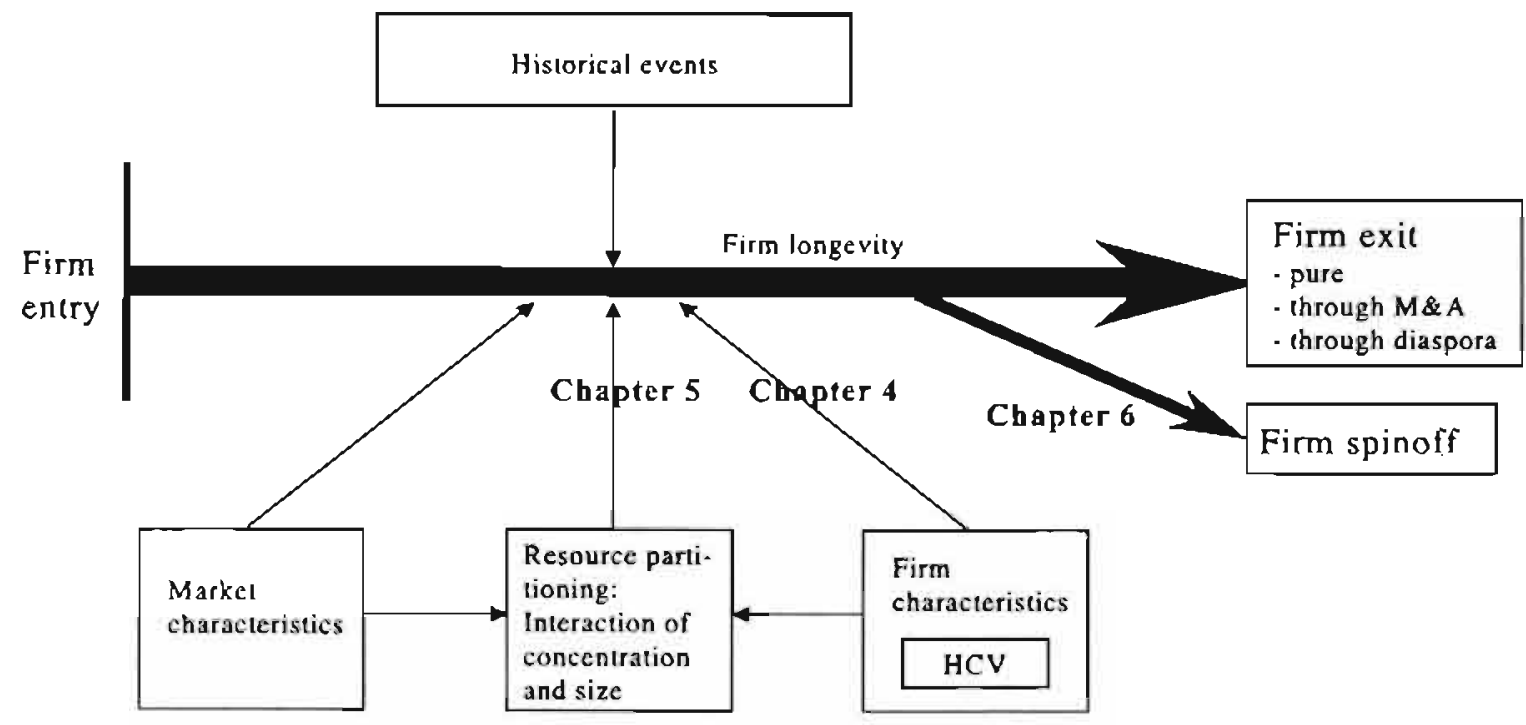

Note: $\mathrm{HCV}=$ human capital variables . 
the performance of audit firms (see Figure 1.2). It does this by considering both the chance of overall exit and the chance of different modes of exit. These different modes of exit are: pure exit, exit by merger or acquisition (M\&A), and exit by diaspora (i.e., the firm falls apart, and all auditors go their own way). The more common firm and market variables are included as control variables, which allows measurement of the additional effect of human capital within a firm on its years of survival. In recent years, both industrial organization and organizational ecology have included human capital theory to explain organizational performance (Boone and van Witteloostuijn, 1996). Human capital theory studies the influence of human capital features such as education, firm experience and personality traits on organizational success. Therefore, both theoretical streams are taken as a starting point. Furthermore, this chapter provides an overview of audit market research.

Chapter 5 takes up the second research question. It tries to broaden the framework of Chapter 4 by including the interaction of market concentration and firm size as another variable explaining the survival chances of audit firms (see Figure 1.2). Hereby, all variables of Chapter 4 are included as covariates. Therefore, based on resource partitioning theory, it analyzes the influence of market concentration and firm size on the chances of survival, and thereby exit, of audit firms. Key variables in this chapter are the concentration rate, the size of the firm, and interactions between these variables.

Next, Chapter 6 deals with the third research question. It considers an important characteristic of audit markets: the high incidence of spinoffs. Within the audit market the spinoff is a common phenomenon. There are many examples of individuals already working as an auditor who leave their firm to found a new audit firm. This chapter tries to explain when and which firms are mostly at risk of having these spinoffs. So it considers the characteristics of the parent firm (firm characteristics) and market characteristics in order to explain why spinoffs occur (see Figure 1.2).

The empirical Chapters 4,5 and 6 are all related by the fact that they study firm dynamics and longevity. Together they provide an overall picture of the determinants of firm survival, exit and spinoff. However, from Figure 1.2 we also learn that each of these three chapters deals with a specific sub-topic of longevity, as indicated by the arrows. Note that part of the terminology of each empirical chapter is different, because each chapter is based upon a different literature and, at least partially, a different theoretical apparatus. Chapters 4,5 and 6 are written such that they can be read independently from each other.

Finally, Chapter 7 combines all the results presented in the previous chapters and states the most important strengths and weaknesses. Furthermore, it provides suggestions for further research. 


\section{Chapter 2}

THE DATA

\subsection{Introduction}

This chapter provides an overview of the data analyzed in this thesis. To provide more insight into the Dutch audit industry, Section 2.2 contains a brief qualitative description of the evolution of the Dutch audit market. Section 2.3 discusses the outlines and the method of collection of the database. Section 2.4 describes in further detail how the dynamic database for the empirical analyses was constructed. Section 2.5 reports the descriptive statistics of the data. In doing so, it makes a distinction between industry level statistics, audit firm statistics, entry and exit related statistics, and firm size related statistics. Finally, Section 2.6 summarizes.

\subsection{Evolution of the Dutch audit market in a nutshell}

\subsubsection{The first auditor}

The first individual that was to some extent comparable to the auditor, appeared in the Middle Ages (de Vries, 1985). However, the profession of the modern auditor was not founded until the end of the 19th century, as a result of the rise of the modern corporation and the concomitant separation between ownership and control. At that time bookkeeping, both in theory and practice, already had a rich history, stemming from the economic prosperity in the 17 th century. In 1879 , as a result of a financial fraud scandal by a large Dutch company, another large Dutch firm decided to hire the first external / independent controller (de Vries, 1985). The name of this first auditor was B.P. van IJsselstein. With his establishment, a whole new profession arose in the Netherlands, which quickly increased in importance.

This historical description of the Dutch audit market is limited in the sense that it only focuses on the characteristics that are of importance for a study into firm dynamics. Key sources are de Vries (1985), and de Hen et al. (1995). 


\subsubsection{The supply of auditing}

After B.P. van IJsselstein was hired as the first auditor, many other auditors quickly followed in his footsteps. Furthermore, since the founding of the profession, auditors strove for a reliable profession, to obtain status and power. As a result, as early as 1895 , the profession became more institutionalized with the creation of the first auditors' association, the NIVA (Nederlands Instituut Van Accountants). The quick establishment of this association was a response to what the auditors called the wild growth of the profession. However, because of some differences of opinion within this association, preparations for a second association already began in 1899, resulting in the establishment of a new association in 1902. Many other associations subsequently followed. Furthermore, disputes within the NIVA led to a temporary split in the association. During these early years the profession grew rapidly.

Then, during the $1920 \mathrm{~s}$ and $1930 \mathrm{~s}$, the different associations grew closer together, resulting in several mergers, which had considerably increased the power and importance of the NIVA by 1939. In the meantime, in 1927 , another important association was founded. This association, named the VAGA (Vereniging van Academisch Gevormde Accountants), was specifically targeting academically educated auditors. Finally, at the end of the 1930s, four large auditors' associations remained.

The desire to control the supply of audit services is also reflected in the increasing demands regarding education. As a result, in 1951, almost every auditing assistant not only did his ${ }^{2}$ exams but also followed his education at the NIVA. This was a sign of the emergence of the NIVA (later renamed into the NIvRA (Nederlands Instituut van Register Accountants)) as the monopolist of the supply of auditors in the Netherlands.

Concurrently, there was a trend for audit firms to merge, reaching a peak in 1974. This trend mirrored a similar one taking place within the economy. Until this merging trend, audit firms had always stayed relatively small. The upshot now was a division of the market into a few really large firms and many small firms. This evolution of the Dutch audit market into one with a dual market structure is very characteristic for audit markets in general. Furthermore, in the 1970 s, there was a large number of newly licensed auditors entering the profession, and from the beginning of the next decade, the number of audit firms was growing again.

\subsubsection{The demand for auditing}

As mentioned before, the raison d'être of the audit profession was a result of a demand

2 Of course, when we write he, his, him, one should also read she, her, her. 
for audit services. After the fraud scandal of 1879, which initiated the demand for auditing, the demand never disappeared anymore. So, even before there was any kind of regulation with respect to an audit statement (see also Section 2.2.4), the demand for audit services already existed (see also Buijink, 1992). With a change in Company Law in 1929, the use of audit services increased even further. The main reason for this increase, were the increased reporting requirements for large limited liability companies in combination with the suggestion towards the use of an external auditor in this law (Buijink, 1992). Additionally, World War II increased the demand for audits and related consulting by the Germans.

In the 1970s and 1980s, the demand was increasing again, only now it was caused by regulations that imposed mandatory audits for all kinds of firms (see Section 2.2.4). During these last decades there was also an internationalization process going on in the Dutch audit market, which meant that the large firms joined the large international networks, and that the focus of audit firms towards other countries increased (see, e.g., Maijoor et al., 1998; Post et al., 1998). In this thesis we will, however, not deal with this issue, because the database is restricted to the Dutch audit market as such (see Section 2.3 of this chapter).

\subsubsection{Audit regulation}

Audit regulation has always been an important issue in the audit industry. Almost right from the start members fought to lay down legal rules for the profession. However, they remained unsuccessful for over 80 years.

Finally, during the last decennia of the observation period used in this study, four important major regulatory measures about auditing were enacted in the Netherlands (de Hen et al., 1995; Maijoor and van Witteloostuijn, 1996). Two of these regulate entry into the profession and the conduct of auditors (i.e., supply-side measures), whilst the other two proscribe the types of companies that are submitted to audits (i.e., demandside measures) (Boone et al., 1999). The description of these regulations draws heavily on Maijoor and van Witteloostuijn (1996, p. 554).

Concerning supply-side regulation, several major changes were introduced by the so-called Law on Registered Auditors in 1967.Under that law the NIvRA, for instance, received the sole right to organize the Dutch audit profession, and henceforth all certified auditors (in Dutch known as: Register Accountants, i.e., RAs) had to be a member of the NIvRA (Buijink et al., 1995). The second major supply regulation proscribes rules of conduct for RAs. Specifically, the Professional Code of Registered Auditors of 1972 prevented unduly competition among auditors by means of, for instance, prohibiting advertising and low-balling. However, in 1987 the requirements of this professional code were eased, allowing more advertising for audit firms. 
The demand-side regulations came in two waves. First, the Act on Anmual Accounts of Companies of 1970 obliged all public companies, large private companies and cooperative societies to disclose audited annual accounts. Before 1970, there were only prescriptions for the so-called 'open' public companies, constituting 1.5 percent of the total number of public companies. Second, the scope of the 1970 law was considerably enlarged in 1983 under Title 8 of book 2 of the Civil Code. As of then every public and private company and cooperative society is obliged to disclose annual accounts. Small and medium-sized companies, however, are allowed to submit abridged annual accounts. Furthermore, all large and medium-sized firms are required to have their annual accounts audited (Maijoor and van Witteloostuijn, 1996).

With these laws, the NIvRA as well as its predecessors finally booked results regarding regulation for the audit market, and succeeded in participating in the actual drafting of financial accounting and audit regulation (Maijoor and van Witteloostuijn, 1996). Thus, it is fair to say that effective lobbying has been an important determinant of government intervention (Boone and van Witteloostuijn, 1995). Furthermore, there are several indications that the large audit firms had an especially important influence on, and benefitted most from, the establishment of the regulations. Maijoor and van Witteloostuijn (1996, p. 554), for instance, remark that "Kraayenhof, one of the founders of the leading Dutch audit firm KPMG, played a very important role in the committee preparing the 1970 regulation." Every large audit firm in the Netherlands, without exception, has been founded by members of NIVA which played a major role in the lobbying for regulation from the beginning of the century throughout the 1960s (de Hen, 1995).

\subsection{The database}

This section is based on, and borrows unrestrictedly from, the descriptions of Buijink et al. (1995) and Maijoor et al. (1995) of the database of the Dutch audit market between 1880 and 1990.

\subsubsection{Outline of the database}

The database covers the period from 1880 until 1992. Approximately every two years data are available. In total the data contains 58 observation points. The size of the audit market and the size of the audit firms are measured by the number of auditors. The rationale behind this is that auditors are the most important production factor in the audit industry (Maijoor et al., 1995). So, for each year of observation, data on all auditors (every individual with a degree in auditing) working in the public 
profession have been obtained. For the individual auditor it is known for which audit firm he worked, which auditors' association he was with, whether he had an academic education or not, and often where he came from before he started to work for an audit firm or where he went to after working for an audit firm (Buijink et al., 1995). For the audit firm it is known in which places it was established in a particular year (Buijink et al., 1995). This information enables us to determine when and for how long each individual auditor worked in the public profession. Further, the database identifies when a particular audit firm existed and how many employees it had affiliated in a particular year. In total the data covers 6,724 auditors and 2,234 audit firms. If audit firms changed their names, they were still considered as one and the same firm.

\subsubsection{The method of data collection}

Central to the collection of the data are the membership lists of Dutch auditors' associations. In 1895 the first Dutch auditors' association was founded, the NIVA. After that, many others followed. By 1967 , only one auditors' association remained until 1992, the NIvRA. Appendix 1 sketches the genealogy of the Dutch auditors' associations between 1895 and 1992 (Buijink et al., 1995). Only auditors' associations that merged into the NIvRA are included, because the predecessors of the registered auditors belonged to these associations.

For the data collection extensive archival material was collected. Three categories of data sources were consulted: membership lists, financial directories and other publications. In total 769 archival pieces contributed to the database. Appendix 2 gives a numerical overview of the data sources (Maijoor et al., 1995).

The data collection process differs for three periods in the history of the Dutch audit market (Buijink et al., 1995). These periods are described below.

\section{The pre-1895 period}

In the pre- 1895 period no auditors' association existed. Therefore, the following strategy was used. First a list was compiled with the names of all auditors in the first NIVA membership list. Then these names were traced backward in time in the financial directories of the four most important Dutch cities in terms of the number of auditors living there (i.e., Amsterdam, Rotterdam, the Hague and Utrecht) (Buijink et al., 1995). Finally, the audit firm affiliation of these auditors found in the directories was used to construct an audit firm name and size list for the 1880-1895 period.

\section{The $1895-1920$ period}

From 1895, auditors' association membership lists were available. However, it was not until 1921 that these lists contained information about the audit firm affiliation 
of their members in public practice. Therefore, before 1921, more or less the same data collection strategy was used as for the pre- 1895 period. The only difference is that, from 1895 on, it was possible to combine information from membership lists with information from the financial directories of the four most important Dutch cities (Buijink et al., 1995). Moreover, a financial directory listing all institutions in the Netherlands (in Dutch known as: Financieel adresboek voor Nederland) was available from that time. This directory included audit firms with more than one person. In this period, as in the previous period, audit firms with one auditor were only considered for the four important Dutch cities (Buijink et al., 1995).

\section{The 1921-1992 period}

In this period, membership lists of auditors' associations contained also the audit firm affiliation of their members in public practice (Buijink et al., 1995). So, only membership lists were necessary for collecting the data in this period. Unfortunately, not all membership lists of all auditors' associations have been traced. Therefore, gaps in the data remain. For the 1968-1992 period the data are complete, because from 1968 onwards all auditors in public practice were members of the NIvRA. This was a consequence of the Law on Registered Accountants, which was implemented in 1967 (see Section 2.2.4). ${ }^{3}$

\subsubsection{Completeness of the data}

Appendix 2.3 provides an assessment of the completeness of the data (Buijink et al., 1995). It contains information about the available years of the data, the auditors' associations that are included for each year of observation, the number of auditors in the data, and an estimation of the total number of auditors in the public profession.

In the years before 1968, the total number of auditors in public practice had to be estimated. Between 1880 and 1894 it is the number of auditors working for the audit firms that were identified as existing in the four large Dutch cities (the part in the data) plus an estimate of the number of auditors working in public practice outside these four cities. As an estimate, the percentage of 1895 NIVA members living outside the four cities, rounded to the nearest whole number, was used. Between 1895 and 1920 the number of auditors in public practice in the city directories of the four large Dutch cities was counted. Further, an estimate of the total number of auditors in public practice was made on the basis of the percentage of NIVA auditors among all auditors living in the four large cities. Between 1921 and 1966, whenever possible, the available

3 After 1993, which is after the period considered in this thesis, the NIvRA lost its sole rights on performing audits again, because also a selected group of 'administrative auditors' of the NOVAA got the rights to perform audits (Maijoor et al., 1995). 
membership lists were used to determine the number of auditors in public practice. With respect to association membership lists for which this was not possible, the nearest subsequent membership lists that gave the necessary information were consulted. Between 1968 and 1992 the NIvRA membership lists provided the real total number of auditors in public practice. In this period one four-year gap remains, because the NIvRA did not publish any membership list in 1976.

\subsection{The dynamic database}

In the previous section, the outlines of the general database have been explained. With this database as a starting point, a dynamic database was constructed. This was done to make it possible to follow the audit firms through time, and thus to study their lives in terms of longevity, exit and spinoff (see also Chapter 3 ). Every audit firm from founding until exit is included in this database. To use time-varying covariates in analyzing the data, every observation year was used to construct a case period. If, for example, a firm was founded in 1980 and disappeared from the original database in 1988, then this firm appears four times in the dynamic database in the periods 1980$1982,1982-1984,1984-1986$ and 1986-1988, with an exit after 1986. In every particular period, not only the characteristics of the firm at founding but also the characteristics of the firm in that particular period are included (e.g., total number and average experience of the auditors). As can be seen from the example above, longevity was calculated as conservatively as possible. The longevity of a firm ends immediately after the last year of an observation. ${ }^{4}$ The conservative measurement of longevity was done to diminish time aggregation bias (see Chapter 3, Section 3.7.2). Of course, all firms that did not yet experience an event at the end of the observation period, i.e., all censored data, were included as well (see Chapter 3, Section 3.2.1). Further, in the dynamic database the firms that entered in 1992 are not included, because these firms no longer have the opportunity to experience an exit in the period of study. Therefore, the number of firms used in the analyses was reduced to 2,068 , instead of the original number of 2,234 audit firms.

4 In this, we of course accounted for missing observations through data restrictions. For example, when a firm was in the dat base in 1914 and 1918, but was missing in 1916 (due to the absence of a membership list), then longevity was measured by assuming that the firm continued during the period 1914-1918, i.e., there was no exit and corresponding entry in this period. 


\subsection{Descriptive statistics of the data}

When studying the Dutch audit industry, two levels of analyses can be distinguished: the audit industry level and the audit firm level. The descriptive statistics of these levels are considered in Sections 2.5.1 and 2.5.2. Furthermore, two other characteristics of the audit industry are important in this thesis: the modes of entry and exit of audit firms (see also Chapters 4 and 6) and the size of audit firms (see particularly also Chapter 5). The descriptive statistics relevant for these characteristics are given in Sections 2.5.3 and 2.5.4.

\subsubsection{Industry level statistics}

The industry level is the most aggregate level. Here, variables like the density (i.e., the number of existing firms in the industry) and the concentration ratio (i.e., the ratio that gives an indication of the size distribution within the market) are important variables that characterize the market. In addition, the net entry of firms (with respect to the last observation), the number of auditors, and the net entry of auditors give a description of the industry. For the Dutch audit market, Table 2.1 provides the descriptive statistics of density, net entry of firms, number of auditors, net entry of auditors, and two concentration ratios.

Table 2.1: Descriptive statistics of the industry level variables

\begin{tabular}{lrrrrr}
\hline Variable & $\begin{array}{r}\text { Number of } \\
\text { observations }\end{array}$ & Minimum & Maximum & Mean & $\begin{array}{r}\text { Standard } \\
\text { deviation }\end{array}$ \\
\hline Density (of firms) & 58 & 1 & 613 & 214.19 & 19.75 \\
Net entry firms & 58 & -218 & 248 & 10.57 & 8.90 \\
Number of auditors & 58 & 2 & 3143 & 731.53 & 106.38 \\
Net entry auditors & 58 & -395 & 451 & 54.19 & 15.78 \\
C4 & 58 & 9.07 & 100 & 33.98 & 3.71 \\
C8 & 58 & 13.15 & 100 & 44.10 & 3.64 \\
\hline
\end{tabular}

C4/C8: The market share of the four/eight largest audit firms in the market in terms of auditors affiliated.

The density varies between 1 and 613 firms, and is most of the time somewhere around 214 firms. The net entry of firms is in general a small positive number, indicating that the market is growing. The number of auditors varies between 2 and 3,143. Further, it has a mean of 731.53 and a relatively small standard deviation. The net entry of 
auditors is, on average, 54.19 with a relatively small standard deviation. The $\mathrm{C} 4$, the percentage of auditors affiliated with the largest four firms in the market, varies between 9.07 and 100 . The mean of the $\mathrm{C} 4$ is 33.98 , and because of the relatively small standard deviation we can conclude that most of the time the $\mathrm{C} 4$ is somewhere around this mean. The $\mathrm{C} 8$, the percentage of auditors affiliated with the largest eight firms in the market, is most of the time somewhere around 44 percent. In this table, as well as in Table 2.2, the minimum and maximum values are influenced by data restrictions relating to the availability of membership lists in the early years and in World War II. As can be seen from Appendices 2.1 and 2.3 not all membership lists are always available, which can cause deviations in the figures. These missing data are, however, accounted for when determining firm entries and exits (see footnote 3).

\section{The development of the number of auditors and of the density}

Figures 2.1 and 2.2 illustrate the development of the number of auditors and of the density (of firms), respectively. The number of auditors is shown as a steadily increasing exponential function between 1880 and 1992 . In the early years of the industry the number of auditors grew slowly. After 1920 the growth rate increased somewhat, and from 1960 on the number of auditors grew rapidly. The number of audit firms has also evolved considerably during the years of existence of the market. Before 1900 there were only a few firms. But from 1900 until the end of the 1930 s the number increased. After World War II the number of audit firms began to fluctuate, displaying a somewhat downward trend. But from 1970 on there has been renewed fast growth.

\section{The development of concentration}

Figure 2.3 shows the development of the $\mathrm{C} 4$. Because the audit market is studied from its early history, the $\mathrm{C} 4$ was at first very high. But, as a result of the rapid institutionalization of the audit profession, the number of firms also grew fast. Therefore, the $\mathrm{C} 4$ decreased rapidly, and stayed low (between 10 and 18 percent) for a long time, approximately from 1900 until 1960 . After 1960 some large firms began to evolve, and the C4 rose again. Since 1970 the four largest firms have had approximately 45 percent of the market.

5 Because of fluctuations in the availability of the membership lists of the numerous auditors' associations, the development in the 1920 s and around World War II fluctuates more than in reality. However, the trend can be recognized. 


\section{CHAPTER 2: THE DATA}

Figure 2.1: The number of auditors in the Dutch audit industry between 1880 and 1992

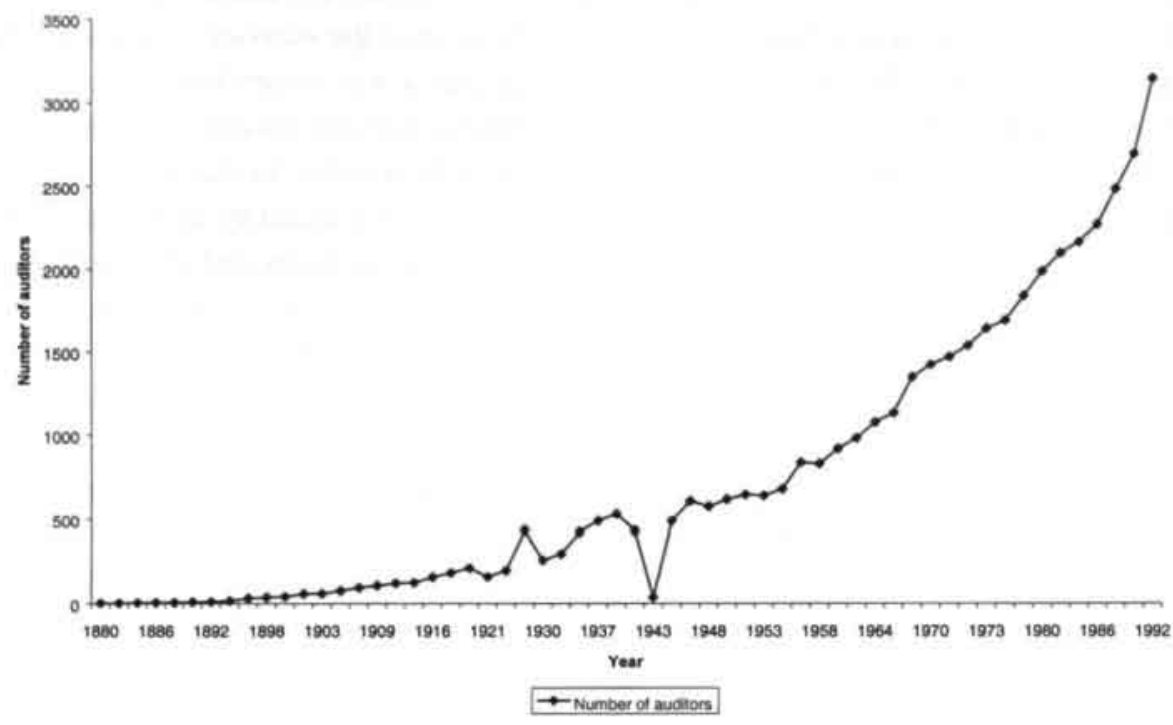

Figure 2.2: The number of audit firms in the Dutch audit industry between 1880 and 1992

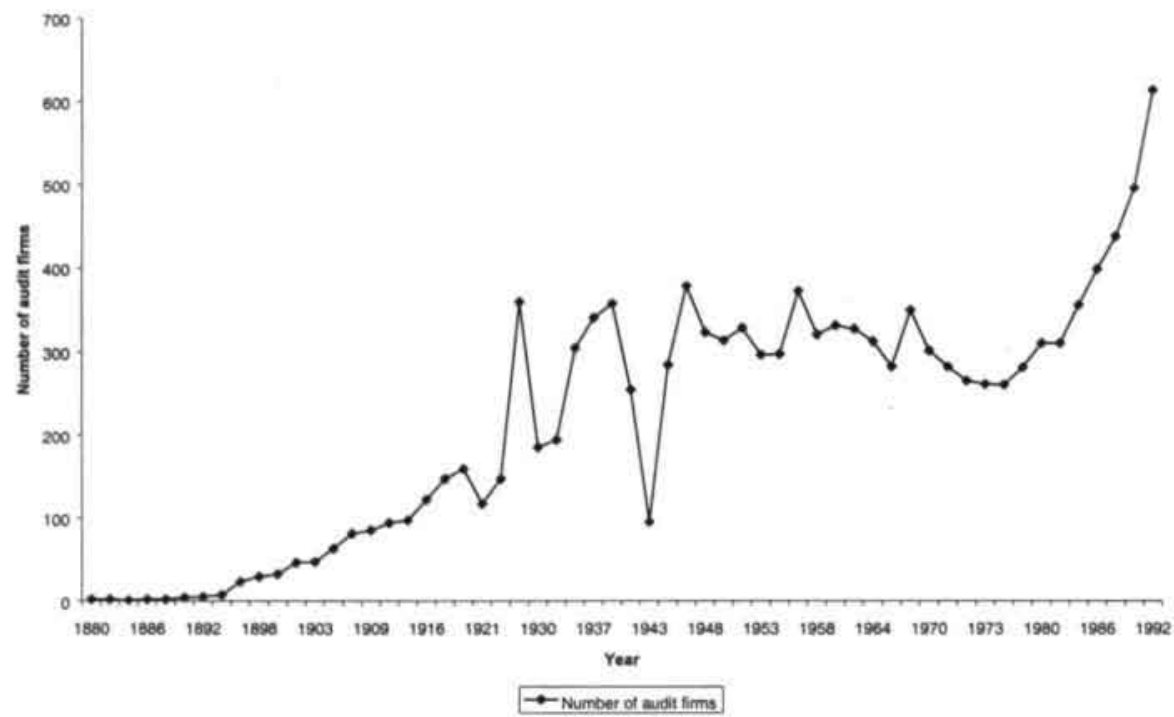


Figure 2.3: The C4 of the Dutch audit industry between 1880 and 1992

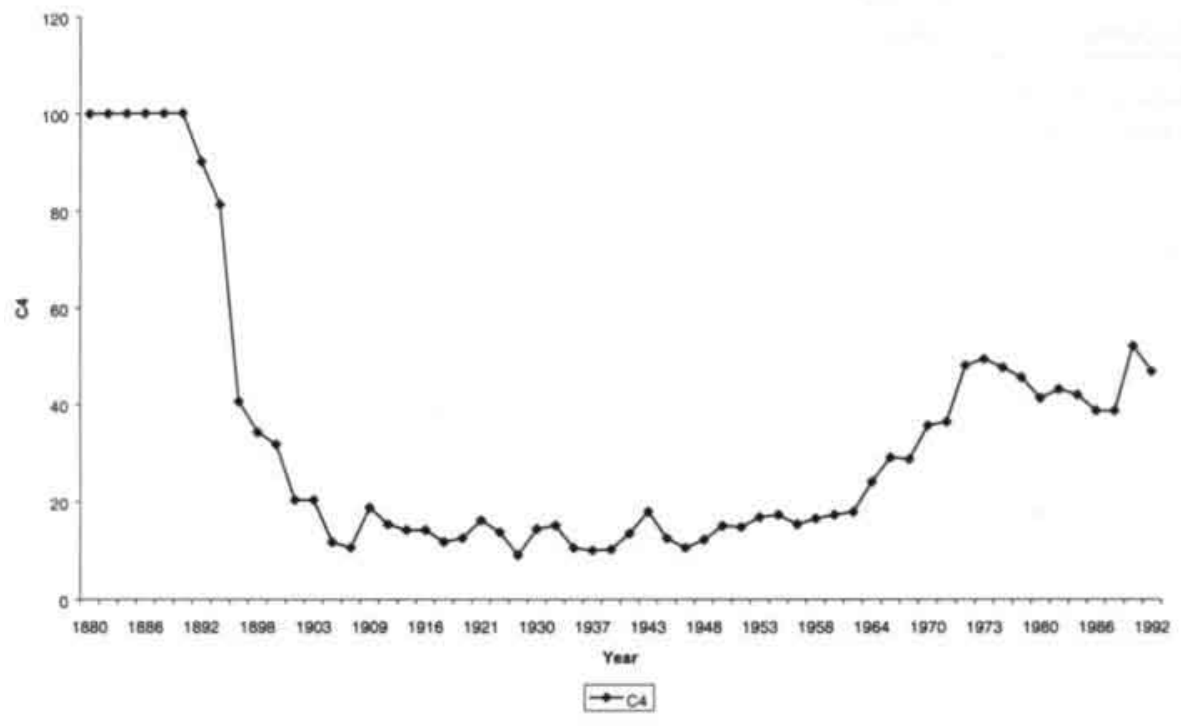

\subsubsection{Audit firm statistics}

The firm level statistics provide information about the characteristics of the firms within the market. These characteristics can be divided into characteristics at founding of the firm, characteristics through time of existence of the firm and characteristics at the time of exit of the firm. The total number of years of longevity is also an important firm variable. The audit firm variables and their descriptive statistics are given in Table 2.2.

The firms that exit the market before the end of the observation period had an average longevity of approximately 12 years. As can be seen from the number of observations, 427 firms survived until the end of the period of study. In general, the size of a firm at founding was 2.55 auditors, approximately $23 \%$ of the founding auditors were academically educated and the founders had an average of 3.76 years of experience, all with large standard deviations. Moreover, Table 2.2 shows that the mean size of the firm and the average years of experience through time were higher than at founding, whereas the mean of the percentage of academically educated auditors is lower over time than at founding. However, none of these differences between founding and through time are statistically significant (measured with t-test statistics). 
Table 2.2: Descriptive statistics of the audit firm level variables

\begin{tabular}{|c|c|c|c|c|c|}
\hline Variable & $\begin{array}{r}\text { Number of } \\
\text { observations }{ }^{6}\end{array}$ & Minimum & Maximum & Mean & $\begin{array}{r}\text { Standard } \\
\text { deviation }\end{array}$ \\
\hline $\begin{array}{l}\text { Longevity until } \\
\text { exit (in years) }\end{array}$ & 1641 & 1 & 81 & 12.25 & 12.88 \\
\hline \multicolumn{6}{|l|}{ At founding? } \\
\hline Net entry & 2068 & -218 & 248 & 11.05 & 74.40 \\
\hline $\begin{array}{l}\text { Size (in audi- } \\
\text { tors) }\end{array}$ & 2068 & 1 & 516 & 2.55 & 17.87 \\
\hline Education $^{8}$ & 1746 & 0 & 100 & 23.30 & 40.12 \\
\hline Experience $^{9}$ & 1746 & 0 & 41 & 3.76 & 6.38 \\
\hline Year & 2068 & 1880 & 1990 & 1952.11 & 26.63 \\
\hline \multicolumn{6}{|l|}{ Through time } \\
\hline Size & 11717 & 1 & 516 & 3.66 & 19.19 \\
\hline Education & 10564 & 0 & 100 & 22.52 & 37.87 \\
\hline Experience & 10564 & 0 & 66 & 10.63 & 8.76 \\
\hline Year & 1641 & 1883 & 1991 & 1956.50 & 22.69 \\
\hline
\end{tabular}

\subsubsection{Statistics of entry and exit}

There are four modes of entry and three general modes of exit, with a division of three more specific modes of exit in one category. These are described below. Furthermore,

- At the audit firm level the entrants of 1992 are not included in the analysis, because these entrants do not have the possibility to exit again within this study's time frame (see also Section 2.4). The number of observations varies depending on the time period considered (so whether it is at founding or through time), and depending on missing observations regarding education and experience.

7 Market variables at founding are always taken one year before the firm enters the data set. The reason for this is that the market variables are considered to be possible causes of firm events such as entry. Therefore, the minimum for the density or $\mathrm{C} 4$, for example, can be zero (i.e., in 1879).

8 Education is the percentage of academically educated auditors within the firm.

9 Experience is the mean of the total years of experience in the profession of all auditors within the firm. 
the development of the number of audit firms who exit the market and the development of the number of spinoffs in the market, i.e., the dependent variables of respectively Chapters 4 and 5 and Chapter 6, are presented. Finally, some descriptive statistics of the entry and exit modes are given.

\section{Modes of entry}

The four categories of entry distinguished in this thesis are:

- Pure entry: the main characteristic of this group of entering firms is that their auditors were not auditors in public practice the year before entry of the firm. So, this mode of entry concerns newly licensed auditors and auditors who come from the non-public accounting sector (e.g., from business sectors).

- Entry by merger: two or more firms join together and change their names into a new one. The firms are thus creating a new firm.

- Entry by diaspora: the founders of this new firm were working in public practice the year before, but their old firm broke up and disappeared, causing all auditors to go their own way (which we termed as exit by diaspora). ${ }^{10}$

- Entry by spinoff: the new firm is founded by auditors who leave a bigger firm that is still in the market.

The coding process was done as follows. First, all pure entries were identified. This were already 1,573 firms, which accounted for 76.06 percent of all entries. Then the other modes of entry were coded. This was done on the basis of where at least a majority of the auditors came from, with the exclusion of auditors that had a pure entry. Furthermore, to be able to have an entry by merger also at least the majority of the auditors of the old firms had to switch to the newly established firm. Finally, in the few cases that there was no majority, the sequence was merger - spinoff - diaspora. So, if, for example, four from the seven auditors who started a new firm came from another firm that continued to exist, two auditors came from a firm that disappeared through diaspora and the last auditor just entered public practice, then the firm is coded as an entry by spinoff. The reason for this being that four of the six auditors that did not enter public practice this year, but came from another firm that continued to exist. Or, if the new firm has seven auditors, where three came from a three-person firm that exited, three came from a four-person firm that exited and one came from a firm that still exists, then the new firm is coded as an entry by merger.

The distribution over the different modes of entry is given in Table 2.3.

10 Note that this is different from a name change, because not all auditors start to work in this new firm, only some of the auditors decide to start the new firm, while the others, for example, quit working or join an already existing firm. 
Table 2.3: The number of different modes of entry of audit firms

\begin{tabular}{lrr}
\hline Mode of entry & Number & Percentage \\
\hline Pure entry & 1573 & 76.06 \\
Entry by merger & 72 & 3.48 \\
Entry by diaspora & 51 & 2.47 \\
Entry by spinoff & 372 & 17.99 \\
Total: & 2068 & 100.00 \\
\hline
\end{tabular}

Taken over the whole period, the largest group of entry is, by far, pure entry. Furthermore, it seems that entry by spinoff is also fairly common. ${ }^{11}$ Entry by merger and entry by diaspora only occur incidentally.

\section{Modes of exit}

The three main categories of exit distinguished in this thesis are:

- Pure exit: the main characteristic of this mode of exit is that the auditors are no longer working in public practice after the exit. They, e.g., went into business or they retired.

- Exit by merger and acquisition (M\&A): two or more firms decide to work together. If they change their names, they both exit by M\&A. If one of the firms stays alive and the others join this firm (so they all go together under the name of the first firm), then only the joining firms exit by M\&A. Within this category a distinction can be made between M\&A between two small firms, between a small and a big firm and between two big firms. Several decision rules for this small/big distinction are used: the four largest firms, the eight largest firms, the top 5\% of firms of the market in terms of auditors employed, and those firms at the top of the market that together employ $25 \%$ of all auditors. ${ }^{12}$

- Exit by diaspora: a firm exits the market and the auditors all go in different directions. The auditors may then disappear from public practice, found a new firm or go to work with another audit firm.

The coding process was done as follows. First, all pure exits were identified. This were already 1067 firms, which accounted for 64.41 percent of all exits. Then the other modes of exit were coded. This was done on the basis of the following rule.

1 Both Chapter 6 and Buijink et al. (1998) show that entry by spinoff is a more recent phenomenon, indicating that the different modes of entry are not evenly spread through time.

12 This distinction is made because it provides the opportunity to study differences between small and large firms, which is an important characteristic of the audit market (see Section 2.2.2). 
If at least half of all auditors went to one and the same firm, then the exit was coded as M\&A. If not, then it was coded as diaspora. So, if a firm consisted of seven persons of which four go to work for another firm, two have a pure exit and one goes to another firm, then the firm was coded as an M\&A exit. Or, if two of the auditors in this seven person firm went to one firm, two to another firm and three had a pure exit, then the exit was coded as a diaspora.

The distribution over the different modes of exit is given in Table 2.4.

Table 2.4: The number of different modes of exit of audit firms

\begin{tabular}{lrr}
\hline Mode of exit & Number & Percentage \\
\hline Pure exit & 1057 & 64.41 \\
Exit by M\&A (small/small) & 419 & 25.53 \\
Exit by M\&A (small/big 4) & 89 & 5.42 \\
Exit by M\&A (big 4/big 4) & 2 & 0.12 \\
Exit by diaspora & 74 & 4.51 \\
Total: & 1641 & 100.00 \\
\hline
\end{tabular}

Just as with the different modes of entry, the mode of exit that occurs most often is pure exit. Furthermore, exit by M\&A between two small firms is fairly common. Exit by M\&A between a small and a large firm and exit by diaspora are definitely less common. Finally, exit by M\&A between two large firms occurs just twice.

\section{The development of the number of exits}

Figure 2.4 shows the development of the number of exiting firms from the Dutch audit market. The number of exits is low until approximately 1920 . After 1920 it varies a lot within a range of about 10 to 80 exits in a year. The observation for 1932 is an outlier. In that year, a number of smaller professional organizations disappeared and they stopped publishing membership lists. We checked whether the firms in their lists appeared in the lists of other existing professional organizations. If this was not the case, these firms were treated as exiting firms.

\section{The development of the number of spinoffs}

Figure 2.5 illustrates the development of the number of spinoffs in the Dutch audit Until 1913 there are almost no spinoffs in the Dutch audit industry. After 1913 spinoffs begin to appear in the market. However until 1970 the number of spinoffs stays relatively small, with fluctuations between approximately 0 and 10 . Finally, in the last two decades 


\section{CHAPTER 2: THE DATA}

Figure 2.4: The number of exits in the Dutch audit market between 1880 and $1990^{13}$

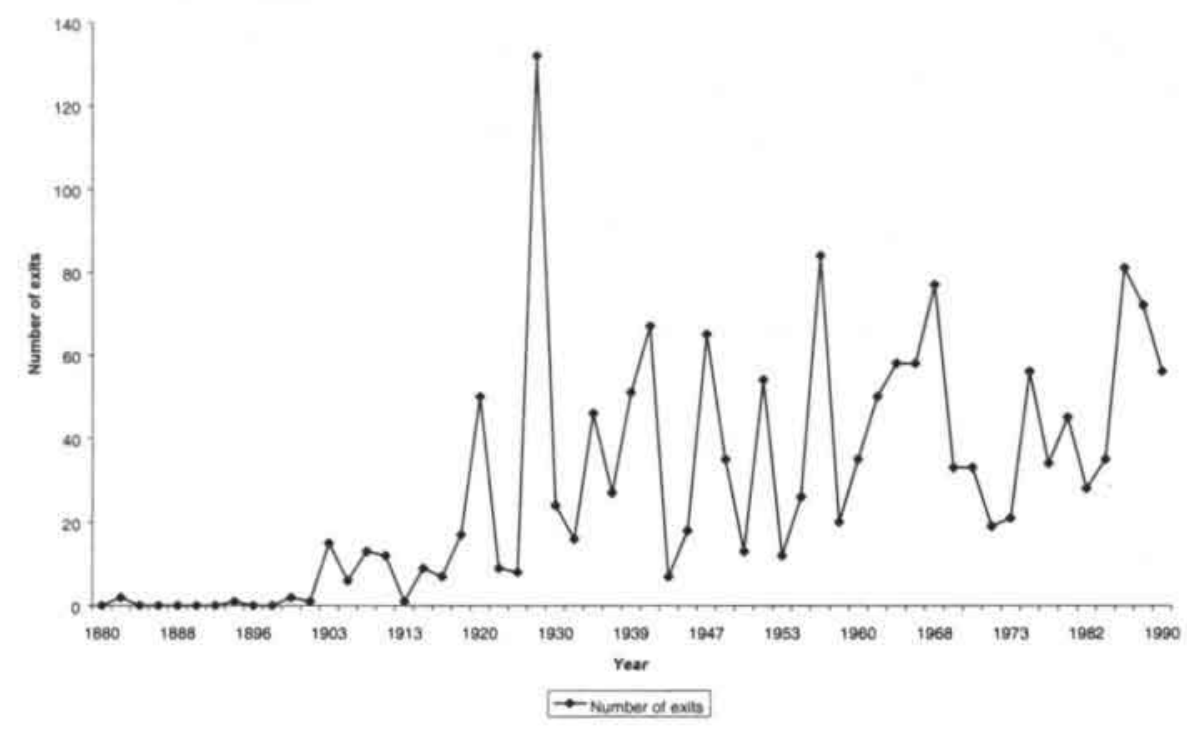

Figure 2.5 The number of spinoffs in the Dutch audit market between 1880 and 1990 market

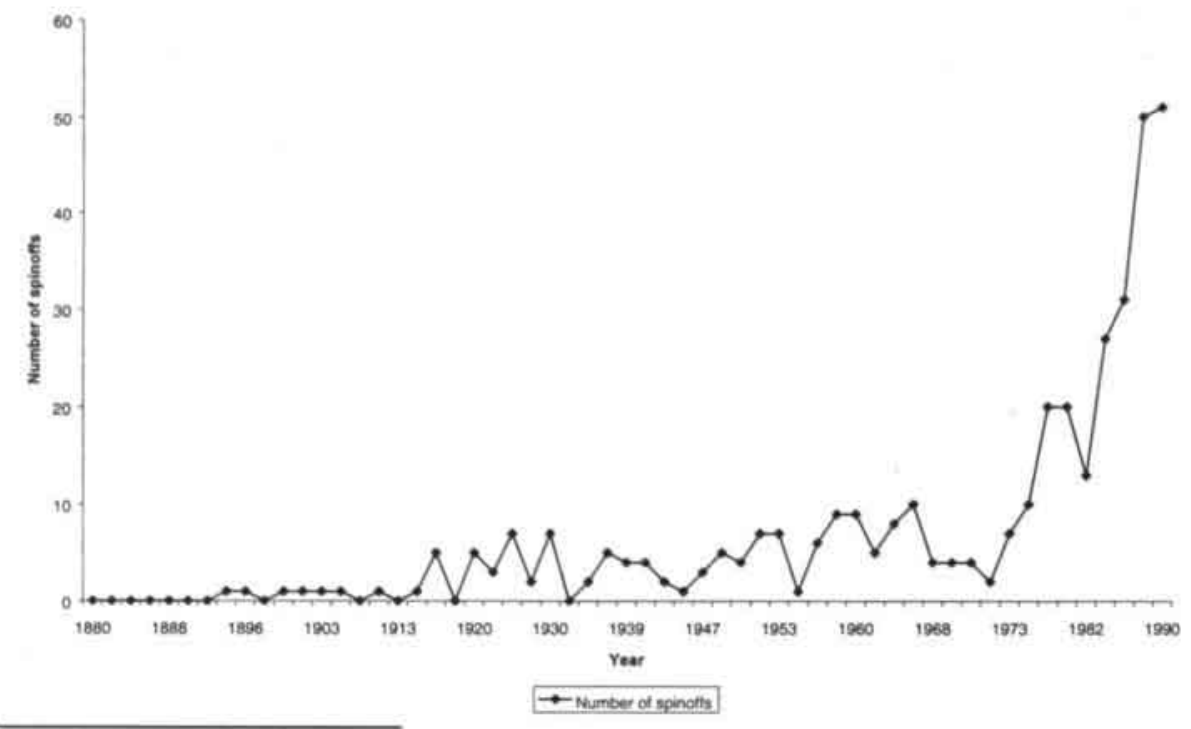

${ }^{13}$ Exits reported in observation year $\mathrm{t}$ do in fact take place between observation year $\mathrm{t}$ and the next observation point. This is why exits that are reported in 1990, do in fact take place between 1990 and 1992. 
the number of spinoffs starts growing a lot.

\section{Statistics related to the modes of entry and exit of firms}

Table 2.5 presents figures which provide more insight into characteristics of the modes of entry and exit of the audit firms, and the relations between them. As can be seen from Table 2.5, by far the largest group comprises the firms that experienced a pure entry on and a pure exit from the market. This group is followed by the firms that have produced a pure entry but exit by M\&A between two or more small firms. The other combinations all have a percentage of below 7 . Further, there are many differences. For example, it seems that exits by diaspora have, on average, a short longevity, and that entrants by an M\&A have a large size. In general, however, standard deviations are quite large, resulting in few significant differences (t-test statistics).

\subsubsection{Firm size related statistics}

This section discusses two firm size related issues: the development of the size distribution, and the statistics for small and large audit firms at founding. Hereby, size is defined as the number of auditors within an audit firm.

\section{The development of the size distribution}

As stated in Section 2.2.2, the size distribution changed during the period of study. The audit literature has already advanced several explanations for the growth of audit firms (Benston, 1985; Yardley et al., 1992; Maijoor et al., 1995). However, at the same time, small audit firms also seem to possess special advantages for certain clients. Figure 2.6 contains the development of the density for single and non-single proprietorships, and Appendix 2.4 provides an indication of the evolution of the size distribution in the audit market in approximately 10 -year intervals.

Figure 2.6 shows that there are a lot of single proprietorships in the Dutch audit market. Moreover, these single proprietorships cause the many small fluctuations in the density. The number of non-single proprietorships is much lower. In number they, however, follow the same trend of growth as the single proprietorships. Furthermore, the appendix gives more insight into the development of the size distribution. It shows that, at first, there were only a few small firms. The firms grew, but until the 1940s there were still only relatively small firms (in 1941 the biggest one consisted of 18 persons). From the 1950 s onwards bigger firms evolved, and after 1970 some firms became really large. But the small firms also kept growing in number. Therefore, the division between small and big firms widened throughout the existence of the profession. 
Table 2.5: Descriptive statistics for all combinations of entry and exit

\begin{tabular}{|c|c|c|c|c|}
\hline $\begin{array}{l}\text { Mode of exit + } \\
\text { variables } \\
\text { (Min. / Max. } \\
\text { Mean (s.d.)) }\end{array}$ & Pure entry & Entry by merger & $\begin{array}{l}\text { Entry by } \\
\text { diaspora }\end{array}$ & Entry by spinoff \\
\hline
\end{tabular}

Pure exit

\begin{tabular}{|c|c|c|c|c|}
\hline Number & $658(49.85 \%)$ & $7(0.53 \%)$ & $18(1.36 \%)$ & $88(6.67 \%)$ \\
\hline Longevity & $\begin{array}{l}1 / 62 \\
13.29(12.19)\end{array}$ & $\begin{array}{l}11 / 61 \\
23.43(17.46)\end{array}$ & $\begin{array}{l}1 / 42 \\
11.72(10.76)\end{array}$ & $\begin{array}{l}1 / 45 \\
9.94(10.55)\end{array}$ \\
\hline Size & $\begin{array}{l}1 / 58 \\
1.20(2.311)\end{array}$ & $\begin{array}{l}1 / 70 \\
20.43(33.19)\end{array}$ & $\begin{array}{l}1 / 3 \\
1.11(0.47)\end{array}$ & $\begin{array}{l}1 / 3 \\
1.09(0.33)\end{array}$ \\
\hline Experience & $\begin{array}{l}0 / 51 \\
13.47(11.61)\end{array}$ & $\begin{array}{l}2 / 31 \\
18.21(11.28)\end{array}$ & $\begin{array}{l}5 / 31 \\
17.00(7.58)\end{array}$ & $\begin{array}{l}0^{14} / 56 \\
17.59(12.68)\end{array}$ \\
\hline Education & $\begin{array}{l}0 / 100 \\
15.90(35.95)\end{array}$ & $\begin{array}{l}0 / 100 \\
21.51(36.71)\end{array}$ & $\begin{array}{l}0 / 100 \\
11.11(32.34)\end{array}$ & $\begin{array}{l}0 / 100 \\
15.91(36.00)\end{array}$ \\
\hline \multicolumn{5}{|l|}{$\begin{array}{l}\text { Exit by } \\
\text { diaspora }\end{array}$} \\
\hline Number & $39(2.95 \%)$ & $10(0.76 \%)$ & $3(0.23 \%)$ & $13(0.98 \%)$ \\
\hline Longevity & $\begin{array}{l}1 / 47 \\
15.23(14.11)\end{array}$ & $\begin{array}{l}1 / 17 \\
6.80(5.20)\end{array}$ & $\begin{array}{l}3 / 9 \\
5.00(3.46)\end{array}$ & $\begin{array}{l}1 / 21 \\
5.08(5.33)\end{array}$ \\
\hline Size & $\begin{array}{l}2 / 27 \\
3.54(3.99)\end{array}$ & $\begin{array}{l}2 / 47 \\
7.70(13.89)\end{array}$ & $\begin{array}{l}3 / 4 \\
3.33(0.58)\end{array}$ & $\begin{array}{l}2 / 8 \\
3.15(1.86)\end{array}$ \\
\hline Experience & $\begin{array}{l}0 / 19 \\
9.10(5.07)\end{array}$ & $\begin{array}{l}7 / 24.5 \\
13.24(6.00)\end{array}$ & $\begin{array}{l}5 / 7 \\
6.00(1.00)\end{array}$ & $\begin{array}{l}5 / 22.5 \\
11.08(5.46)\end{array}$ \\
\hline Education & $\begin{array}{l}0 / 100 \\
24.05(30.43)\end{array}$ & $\begin{array}{l}0 / 66.67 \\
19.28(21.66)\end{array}$ & $\begin{array}{l}0 / 33.33 \\
11.11(19.24)\end{array}$ & $\begin{array}{l}0 / 100 \\
26.28(31.52)\end{array}$ \\
\hline
\end{tabular}

14 On at least one occasion in the data, the minimum average experience of the auditors (in an entry by spinoff) is 0 . The reason for this is the length of the observation spells. When auditors first appear in the database, they are treated as auditors without any experience. However, it is possible that they already started working in the firm before that year, but after the previous year of observation. Therefore, it is possible that old auditors in the firm already disappeared and new auditors appeared, and that they worked together in the same firm, but that the average experience is calculated as 0 . 
CHAPTER 2: THE DATA

Table 2.5 (Continued): Descriptive statistics for all combinations of entry and exit

\begin{tabular}{|c|c|c|c|c|}
\hline $\begin{array}{l}\text { Mode of exit + } \\
\text { variables } \\
\text { Min. / Max. } \\
\text { Mean (s.d.)) }\end{array}$ & Pure entry & Entry by merger & $\begin{array}{l}\text { Entry by } \\
\text { diaspora }\end{array}$ & Entry by spinoff \\
\hline \multicolumn{5}{|l|}{$\begin{array}{l}\text { Exit by M\&A } \\
(\text { small/small) }\end{array}$} \\
\hline Number & $271(20.53 \%)$ & $25(1.89 \%)$ & $13(0.98 \%)$ & $88(6.67 \%)$ \\
\hline Longevity & $\begin{array}{l}1 / 71 \\
14.89(14.14)\end{array}$ & $\begin{array}{l}1 / 33 \\
7.04(7.40)\end{array}$ & $\begin{array}{l}1 / 33 \\
14.00(12.03)\end{array}$ & $\begin{array}{l}1 / 73 \\
9.76(11.19)\end{array}$ \\
\hline Size & $\begin{array}{l}1 / 39 \\
2.28(4.02)\end{array}$ & $\begin{array}{l}1 / 68 \\
14.92(16.45)\end{array}$ & $\begin{array}{l}1 / 26 \\
4.77(7.24)\end{array}$ & $\begin{array}{l}1 / 28 \\
3.43(5.15)\end{array}$ \\
\hline Experience & $\begin{array}{l}0 / 42 \\
9.01(8.35)\end{array}$ & $\begin{array}{l}6.54 / 24 \\
12.26(3.89)\end{array}$ & $\begin{array}{l}6 / 31 \\
16.54(7.58)\end{array}$ & $\begin{array}{l}1 / 34 \\
11.74(6.55)\end{array}$ \\
\hline Education & $\begin{array}{l}0 / 100 \\
24.49(38.41)\end{array}$ & $\begin{array}{l}0 / 100 \\
30.40(26.60)\end{array}$ & $\begin{array}{l}0 / 100 \\
18.54(30.83)\end{array}$ & $\begin{array}{l}0 / 100 \\
30.57(40.00)\end{array}$ \\
\hline \multicolumn{5}{|l|}{$\begin{array}{l}\text { Exit by } M \& A \\
(\text { small/big 4) }\end{array}$} \\
\hline Number & $57(4.32 \%)$ & $7(0.53 \%)$ & $2(0.15 \%)$ & $19(1.44 \%)$ \\
\hline Longevity & $\begin{array}{l}1 / 81 \\
15.12(16.61)\end{array}$ & $\begin{array}{l}3 / 21 \\
12.86(8.03)\end{array}$ & $\begin{array}{l}8 / 22 \\
15.00(9.90)\end{array}$ & $\begin{array}{l}1 / 48 \\
11.53(13.69)\end{array}$ \\
\hline Size & $\begin{array}{l}1 / 79 \\
5.23(13.00)\end{array}$ & $\begin{array}{l}1 / 97 \\
44.71(42.51)\end{array}$ & $\begin{array}{l}1 / 4 \\
2.500(2.12)\end{array}$ & $\begin{array}{l}1 / 165 \\
12.95(36.99)\end{array}$ \\
\hline Experience & $\begin{array}{l}0 / 36.5 \\
9.68(8.68)\end{array}$ & $\begin{array}{l}8 / 18 \\
11.69(4.14)\end{array}$ & $\begin{array}{l}8.5 / 22 \\
15.25(9.55)\end{array}$ & $\begin{array}{l}4 / 25 \\
10.24(5.24)\end{array}$ \\
\hline Education & $\begin{array}{l}0 / 100 \\
27.21(37.82)\end{array}$ & $\begin{array}{l}0 / 100 \\
29.97(32.36)\end{array}$ & $\begin{array}{l}25 / 100 \\
62.50(53.03)\end{array}$ & $\begin{array}{l}0 / 100 \\
49.42(37.38)\end{array}$ \\
\hline
\end{tabular}


Figure 2.6: The number of single and non-single proprietorships in the Dutch audit market between 1880 and 1990

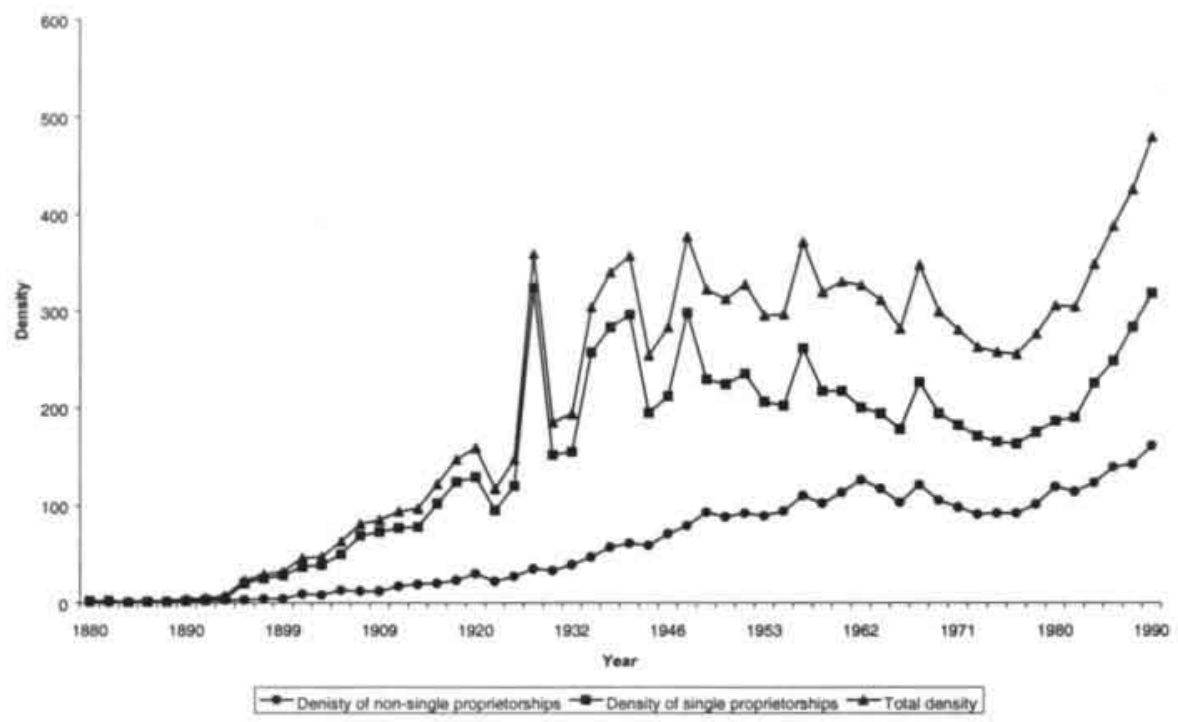

The development of firms that are small at founding versus firms that are large at founding

As mentioned in the previous sub-section, there are especially many single proprietorships and a few large audit firms. This distribution has even widened over time. As the contribution of small firms to economic well-being is undeniable (Carter et al., 1994), it is interesting to examine whether or not there is a difference in the development of single proprietorships at founding and non-single proprietorships at founding. Some material to compare these two groups is provided in Table 2.6.

As we can see from Table 2.6, the longevity of single proprietorships is somewhat larger than for non-single proprietorships. Single proprietorships sometimes grow during their lifetime, but when they exit the market, they have on average 1.58 affiliated auditors. The non-singles, in contrast, have an average 11.05 affiliated auditors when they exit the market. So, both groups slightly grow in terms of the number of auditors employed. The variables experience and education also show some variance, but all with high standard deviations. In effect, only the difference between the mean experience at founding of single and non-single proprietorship is significant. Therefore, the differences can perhaps be explained by considering the different modes of entry and exit. These entry and exit differences between single and non-single proprietorships 
Table 2.6: Comparison between descriptive statistics of single and non-single proprietorships at founding

\begin{tabular}{lll}
\hline $\begin{array}{l}\text { Variable } \\
\text { Minimum / Maximum } \\
\text { Mean (Standard deviation)) }\end{array}$ & $\begin{array}{l}\text { Single proprietorships at } \\
\text { founding }\end{array}$ & $\begin{array}{l}\text { Non-single proprietorships at } \\
\text { founding }\end{array}$ \\
\hline Number $^{15}$ & 1122 & 198 \\
Longevity & $1 / 81$ & $1 / 57$ \\
& $13.60(13.02)$ & $9.90(10.23)$ \\
Size at founding & $1 / 1$ & $2 / 202$ \\
Size at exit & $1(0.00)$ & $8.78(23.15)$ \\
& $1 / 70$ & $1 / 233$ \\
Experience at founding & $1.58(3.46)$ & $11.05(28.26)$ \\
& $0 / 41$ & $0 / 29$ \\
Experience at exit & $2.67(6.13)$ & $8.866^{16}(6.18)$ \\
& $0 / 56$ & $0 / 36.5$ \\
Education at founding & $12.47(10.90)$ & $12.30(6.94)$ \\
& $0 / 100$ & $0 / 100$ \\
Education at exit & $18.90(39.16)$ & $22.91(26.80)$ \\
Density at founding & $0 / 100$ & $0 / 100$ \\
& $19.11(37.28)$ & $27.80(32.41)$ \\
C4 at founding & $5 / 437$ & $36 / 437$ \\
& $252.54(103.26)$ & $276.21(91.73)$ \\
& $9.07 / 90.01$ & $9.07 / 49.38$ \\
& $20.30(11.70)$ & $28.31(13.46)$ \\
\hline
\end{tabular}

at founding are given in Table 2.7.

The percentages for the groups of pure entry and exit are much higher for single proprietorships at founding than for non-single proprietorships at founding. This second group, by definition, witnesses entries by merger and a much higher percentage for entry by spinoff. Therefore, it also seems logical that experience at founding for this group is higher than for the first group. When we look at the other differences between the modes of exit, it seems that merger is far more 'popular' with non-single proprietorships at founding. Obviously, single proprietorships are not attractive take-over

15 Only the firms that experience an exit and that contain data on all the variables, are included in this table.

16 The difference between the mean of experience at founding of single and non-single proprietorships is significant at a 0.05 level. 
Table 2.7: Comparison of the modes of entry and exit between single and non-single proprietorships at founding ${ }^{17}$

\begin{tabular}{lrrrr}
\hline & $\begin{array}{c}\text { Single } \\
\text { proprietorships } \\
\text { at founding: } \\
\text { Number }\end{array}$ & Percentage & $\begin{array}{r}\text { Non-single } \\
\text { proprietorships } \\
\text { at founding: } \\
\text { Number }\end{array}$ & Percentage \\
\hline Entry / exit & 945 & 84.22 & 80 & 40.4 \\
Pure entry & 0 & 0 & 50 & 25.25 \\
Entry by merger & 30 & 2.67 & 6 & 3.03 \\
Entry by diaspora & 147 & 13.1 & 62 & 31.31 \\
Entry by spinoff & & & & \\
Mode of exit & 728 & 64.88 & 43 & 21.72 \\
Pure exit & 307 & 27.36 & 90 & 45.45 \\
Exit by M\&A (small/small) & 55 & 4.9 & 30 & 15.15 \\
Exit by M\&A (small/big 4) & 0 & 0 & 2 & 1.01 \\
Exit by M\&A (big 4/big 4) & 32 & 2.85 & 33 & 16.67 \\
\hline Exit by diaspora & & & & \\
\hline
\end{tabular}

candidates. Furthermore, exit by diaspora is by definition much more common in non-single proprietorships at founding, because single proprietorships first have to grow before they can experience a diaspora event.

\subsection{Summary}

This chapter began with a qualitative description of the Dutch audit market, indicating the most important processes with respect to the evolution of the market. Then, the data collecting process is described, and an overview of the completeness of the data is given. After that, the way to transform the data into a dynamic database is explained. Finally, the descriptive statistics of the data are considered, making a division into industry level statistics, audit firm statistics, entry and exit related statistics, and firm size related statistics.

17 Only the firms that are included in Table 2.6, are also included in this table. 
Appendix 2.1: Genealogy of Dutch auditors' associations between 1895-1992

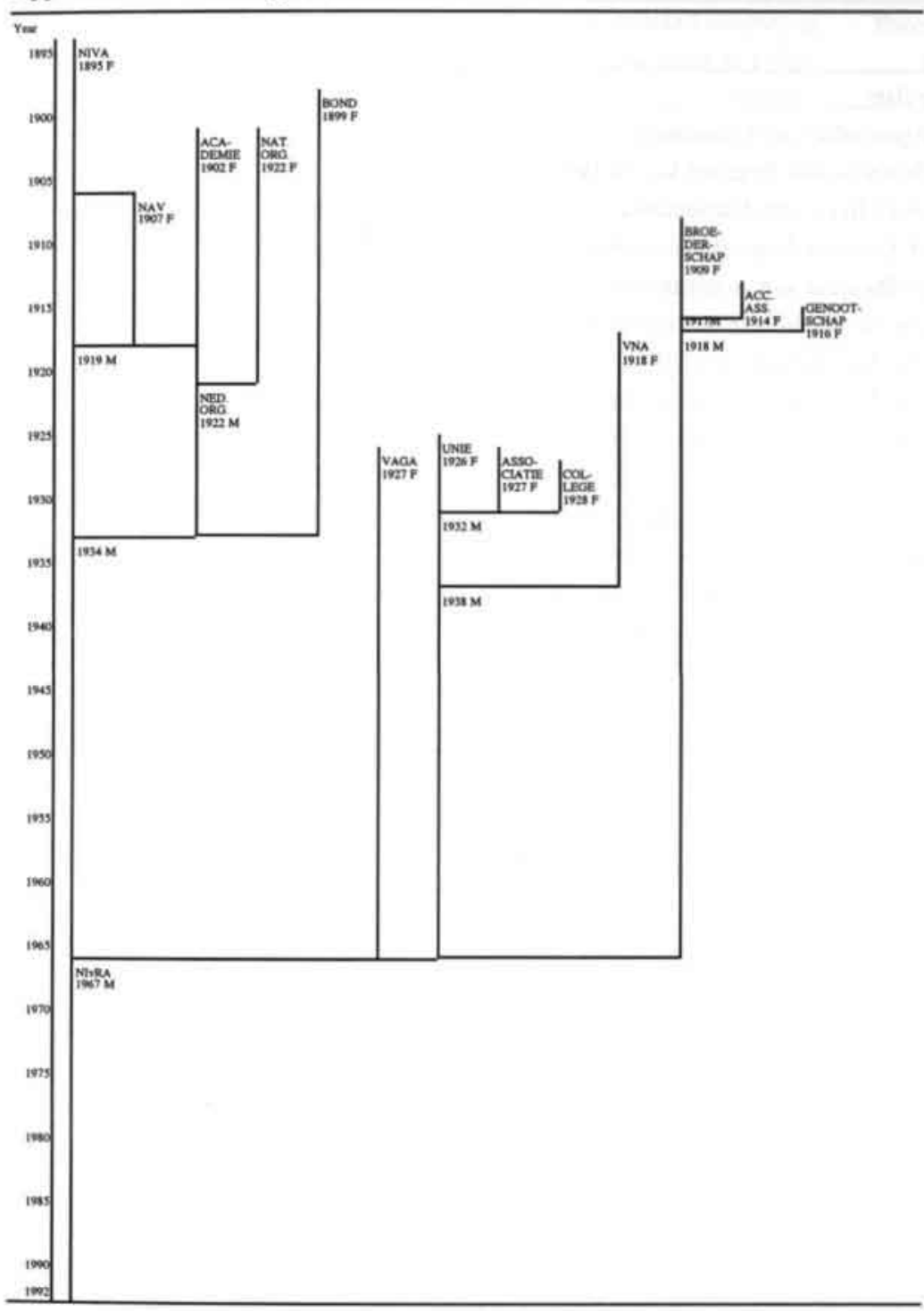

Notes:

Only branches of auditors' associations which merged into the NIvRA are included. Of each auditors' association the date of founding (F) and merger (M) are given. In case of a merger of auditors' associations, the name of the new auditors' association is only given if it differs from the name of the largest preceding auditors' association. Furthermore, the full names of the associations are reported in Appendix 2.2.

Source: Buijink et al. (1995). 
Appendix 2.2: Numerical overview of data sources over 1880-1992

Data source:

Number:

Membership lists:

Nationale Organisatie van Accountants $\quad 18$

Nederlands Instituut van RegisterAccountants $\quad 18$

Nederlandsch College van Accountants 1

Nederlandsch Genootschap van Accountants 3

$\begin{array}{ll}\text { Nederlandsch Instituut van Accountants } & 72\end{array}$

Nederlandsche Academie van Accountants $\quad 14$

Nederlandsche Accountants Associatie $\quad 3$

Nederlandsche Accountants Vereeniging $\quad 9$

Nederlandsche Associatie van Accountants 1

Nederlandsche Bond van Accountants $\quad 29$

Nederlandsche Broederschap van Accountants $\quad 19$

Nederlandsche Organisatie van Accountants 7

Nederlandsche Unie van Accountants $\quad 6$

Vereeniging van Nederlandsche Accountants 9

Vereniging van Academisch Gevormde Accountants 19

\begin{tabular}{ll} 
Total & 228 \\
\hline
\end{tabular}

Financial directories:

$\begin{array}{ll}\text { National directories } & 21\end{array}$

City directories:

Amsterdam $\quad 41$

Rotterdam $\quad 35$

The Hague 41

Utrecht 41

\begin{tabular}{lr} 
Total & 179 \\
\hline
\end{tabular}

Other data sources:

Books and articles audit firms and auditor associations $\quad 15$

Annual reports of auditor associations $\quad 64$

Minutes of auditor association meetings $\quad 276$

$\begin{array}{ll}\text { Professional journals } & 7\end{array}$

Total 362

\begin{tabular}{ll} 
Total & 769 \\
\hline
\end{tabular}

Source: Buijink et al. (1995). 
CHAPTER 2: THE DATA

Appendix 2.3: An estimate of the completeness of the research sample

\begin{tabular}{|c|c|c|c|c|}
\hline Year: & $\begin{array}{l}\text { Auditor association } \\
\text { included in the data }\end{array}$ & $\begin{array}{r}\text { Number of } \\
\text { auditors in the } \\
\text { data } \\
\end{array}$ & $\begin{array}{r}\text { Estimated number of } \\
\text { auditors in public } \\
\text { practice }\end{array}$ & $\begin{array}{r}\text { Percentage in the } \\
\text { database }\end{array}$ \\
\hline 1880 & & 2 & 2 & 100 \\
\hline 1882 & & 2 & 2 & 100 \\
\hline 1884 & & 5 & 6 & 83 \\
\hline 1886 & & 6 & 7 & 86 \\
\hline 1888 & & 6 & 7 & 86 \\
\hline 1890 & & 10 & 12 & 83 \\
\hline 1892 & & 11 & 14 & 79 \\
\hline 1894 & & 16 & 20 & 80 \\
\hline 1896 & 5 & 32 & 40 & 80 \\
\hline 1898 & 5 & 38 & 48 & 79 \\
\hline 1899 & 5 & 41 & 54 & 76 \\
\hline 1901 & 5,10 & 58 & 78 & 74 \\
\hline 1903 & $5,6,10$ & 59 & 90 & 66 \\
\hline 1906 & $1,5,6,10$ & 77 & 98 & 79 \\
\hline 1908 & $1,5,6,8,10$ & 95 & 115 & 83 \\
\hline 1909 & $1,5,6,8,10$ & 109 & 134 & 81 \\
\hline 1913 & $1,5,6,8,10,11,12$ & 123 & 163 & 75 \\
\hline 1914 & $1,5,6,8,10,11,12$ & 126 & 168 & 75 \\
\hline 1916 & $1,4,5,6,7,8,10,11$ & 159 & 212 & 75 \\
\hline 1918 & $1,4,5,6,7,8,10,11,12$ & 185 & 252 & 73 \\
\hline 1920 & $1,4,5,6,10,11,14$ & 213 & 294 & 72 \\
\hline 1921 & 5,10 & 160 & 275 & 58 \\
\hline 1925 & 5,10 & 198 & 328 & 60 \\
\hline 1928 & $3,5,9,10,11,13,14$ & 436 & 464 & 94 \\
\hline 1930 & 5,10 & 259 & 508 & 51 \\
\hline 1932 & 5,10 & 297 & 560 & 53 \\
\hline 1934 & $5,10,13$ & 425 & 570 & 75 \\
\hline 1937 & $5,13,15$ & 489 & 578 & 85 \\
\hline 1939 & $5,13,15$ & 529 & 603 & 88 \\
\hline 1941 & 5,15 & 432 & 578 & 75 \\
\hline 1943 & 15 & 37 & * & $*$ \\
\hline 1946 & 5,15 & 488 & 637 & 77 \\
\hline 1947 & $5,13,15$ & 606 & 668 & 91 \\
\hline 1948 & $5,11,15$ & 574 & 686 & 84 \\
\hline 1950 & $5,11,15$ & 616 & 717 & 86 \\
\hline 1951 & $5,11,15$ & 643 & 742 & 87 \\
\hline 1953 & 5,15 & 637 & 794 & 80 \\
\hline
\end{tabular}




\section{CHAPTER 2: THE DATA}

Appendix 2.3 (Continued): An estimate of the completeness of the research sample

Year: Auditor association in- Number of audi- Estimated number of Percentage of the cluded in the data: tors in the data: auditors in public

database: practice:

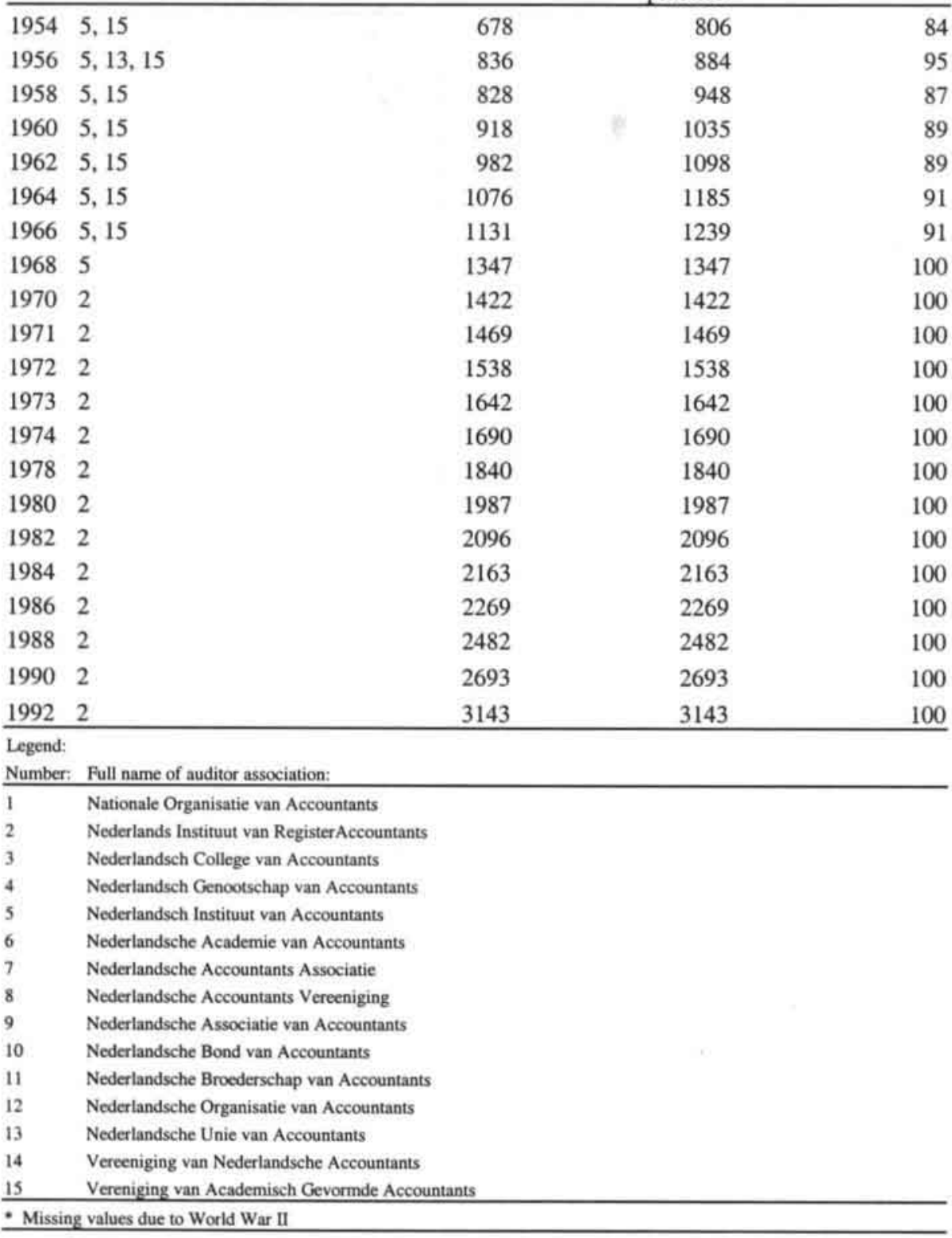

Source: Buijink et al. (1995). 
Appendix 2.4: Size distribution of the Dutch audit market for approximately every 10 years
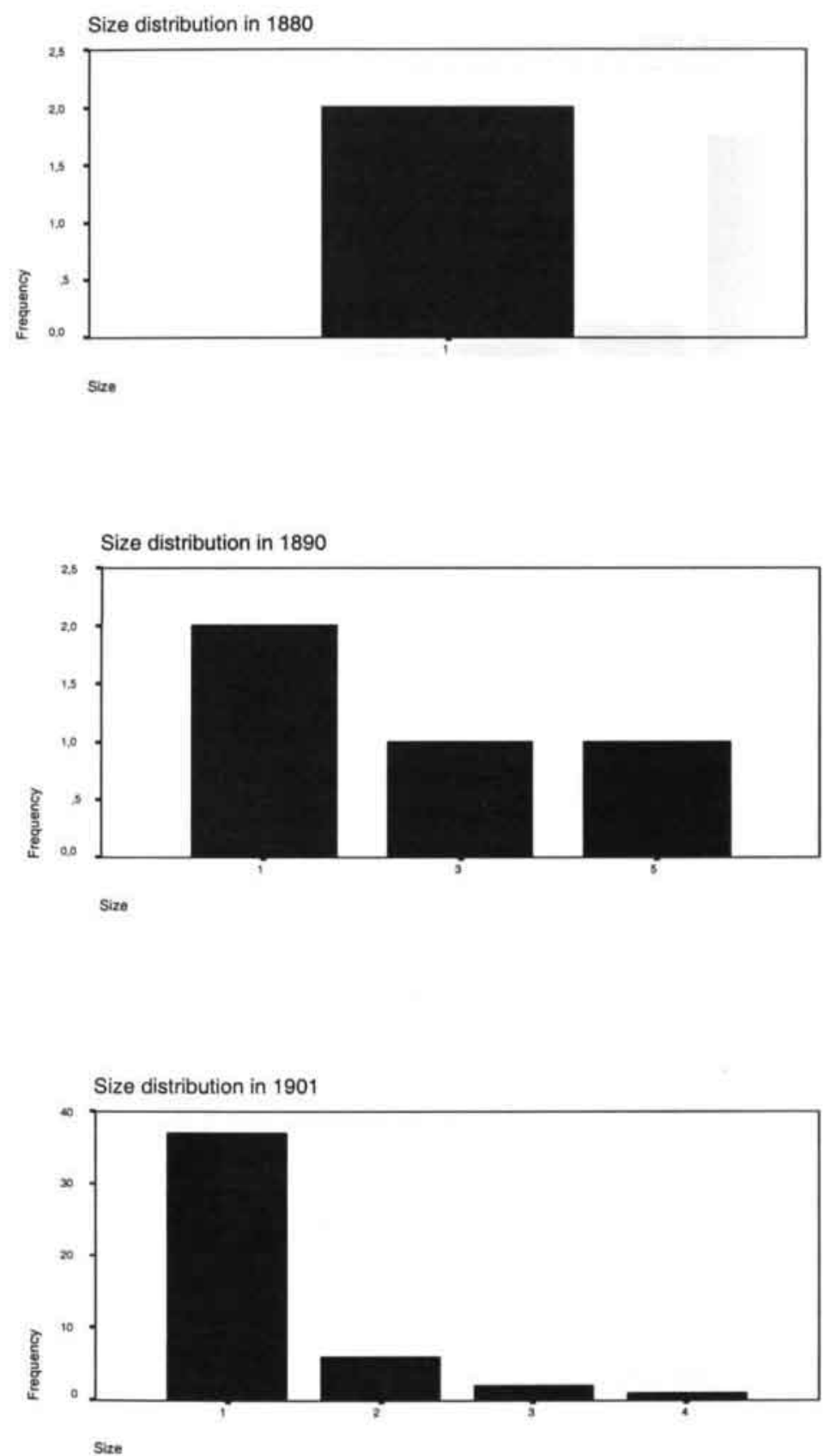


\section{CHAPTER 2: THE DATA}

Appendix 2.4 (Continued): Size distribution of the Dutch audit market for approximately every 10 years

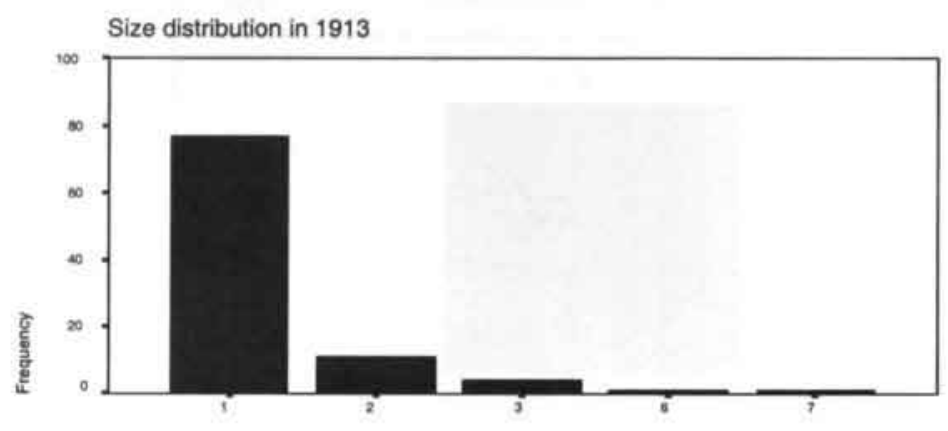

Sire

Size distribution in 1920

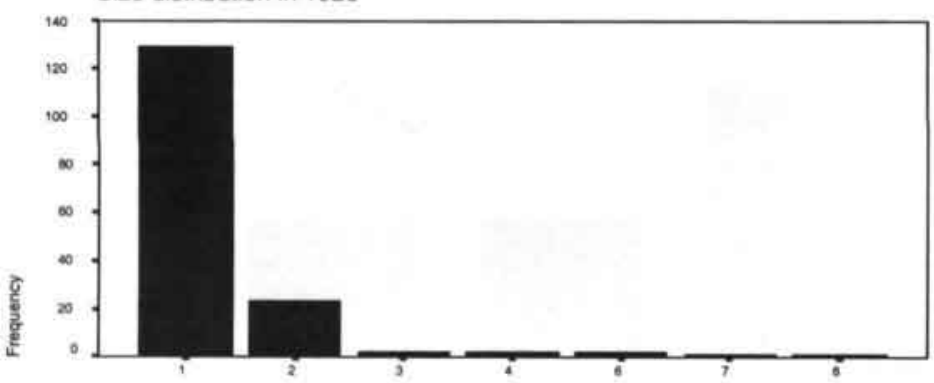

Size

Size distribution in 1930

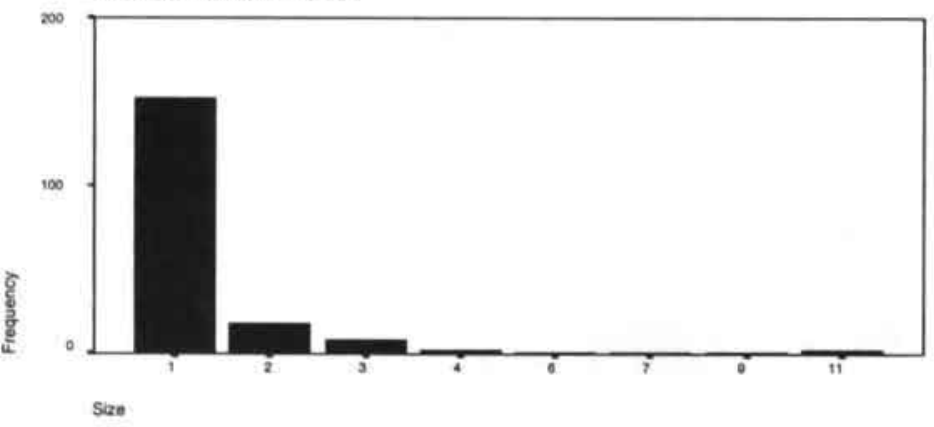


CHAPTER 2: THE DATA

Appendix 2.4 (Continued): Size distribution of the Dutch audit market for approximately every 10 years

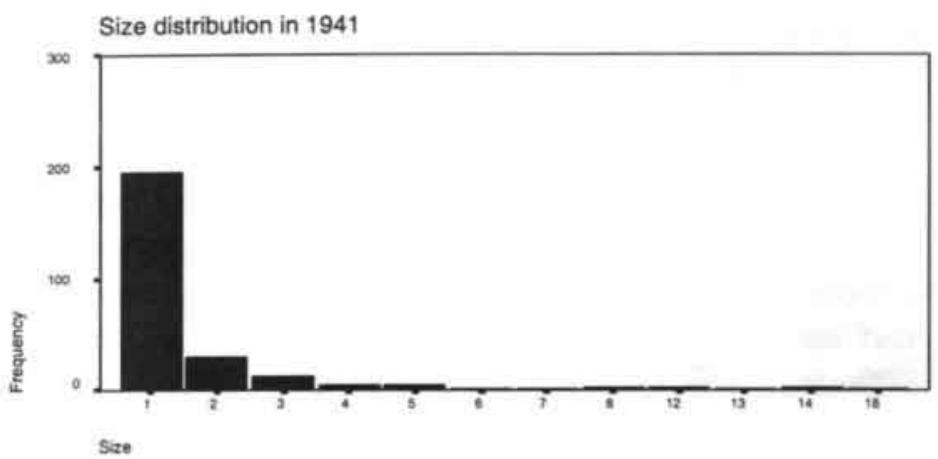

Size distribution in 1950

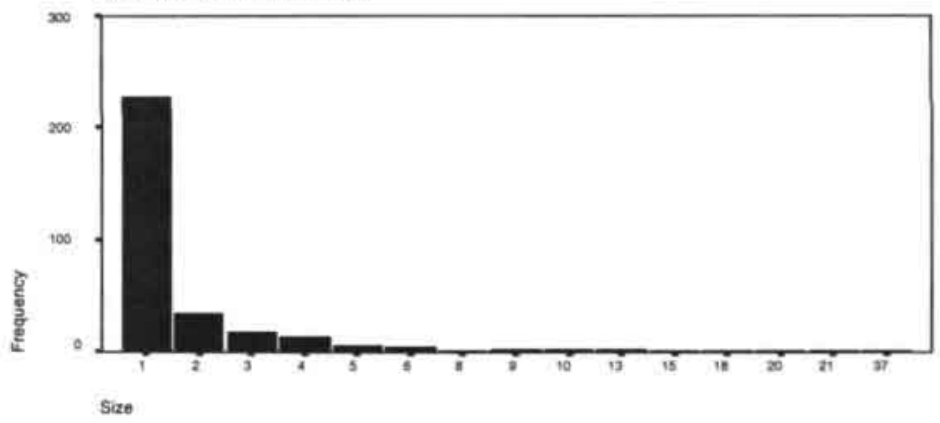

Size distribution in 1960

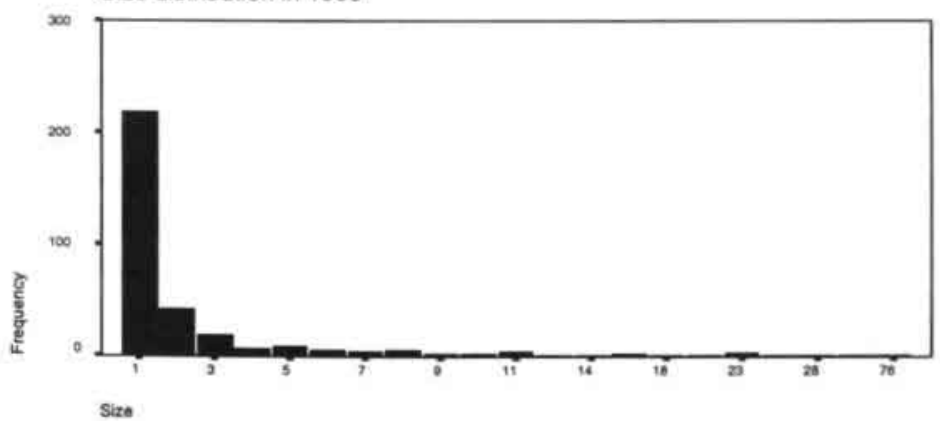




\section{CHAPTER 2: THE DATA}

Appendix 2.4 (Continued): Size distribution of the Dutch audit market for approximately every 10 years
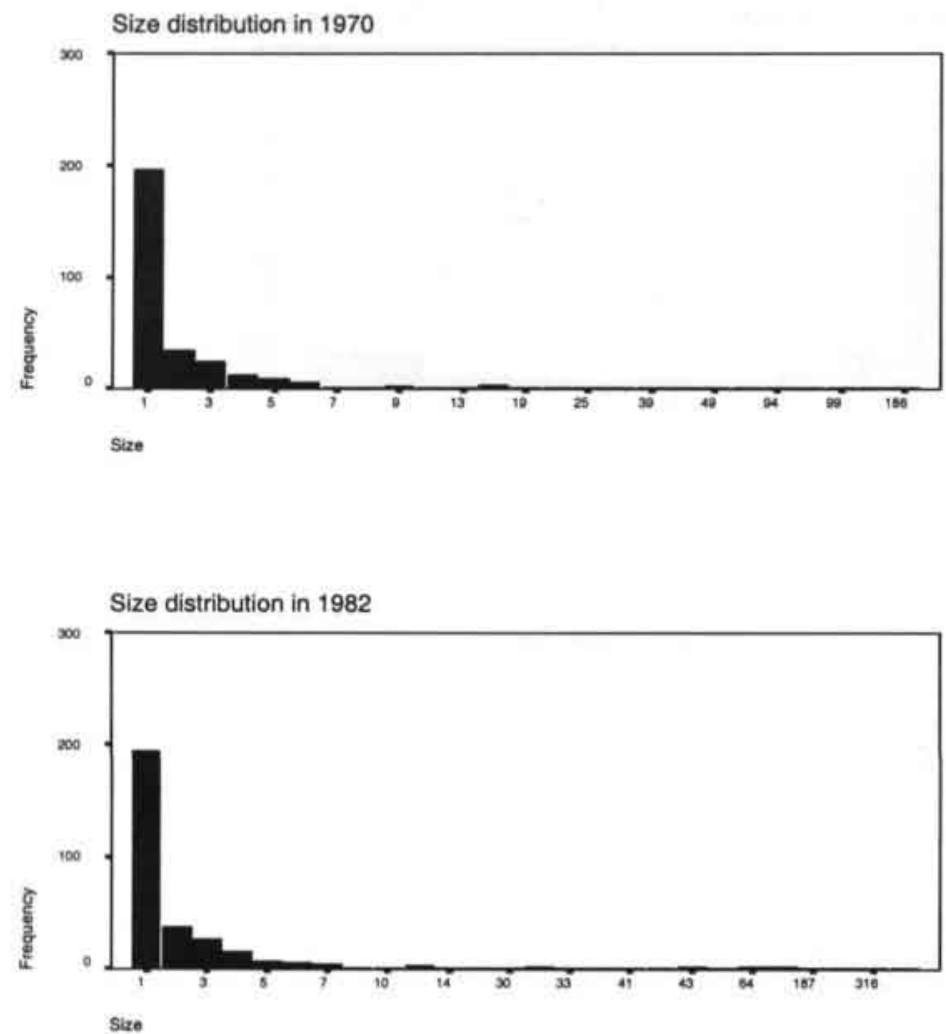

Size distribution in 1990

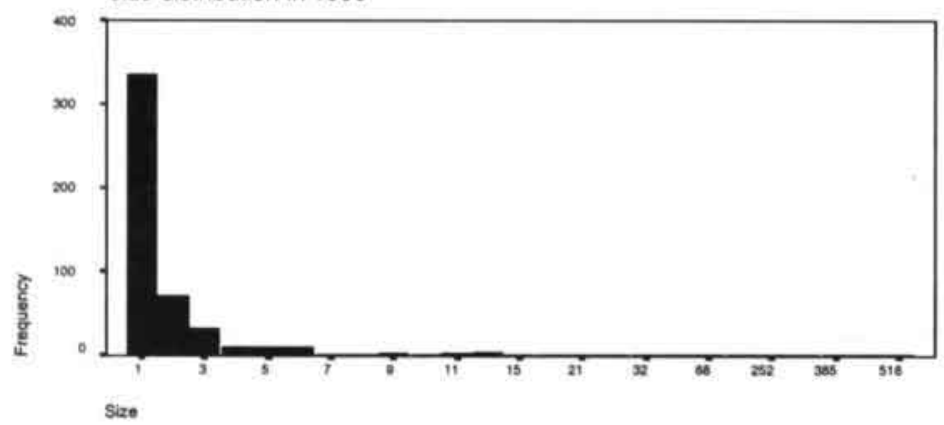




\section{Chapter 3}

\section{EVENT HISTORY ANALYSIS}

\subsection{Introduction}

Firms, just like human beings, are dynamic and experience many events. The first major event for human beings is of course their birth. During their lives they experience all kinds of changes (events), and finally they die. For firms, these events are, for example, establishment, merging, adopting innovations, and going bankrupt (Allison, 1982). The history of a firm can therefore be characterized as a sequence of events. Questions about the causes of such events can best be answered empirically using event history analysis (Allison, 1982). This kind of analysis has spread fairly recently to the economics literature (Greene, 1990). Event history analysis calculates the chance of an event, and possibly estimates the influence of explanatory variables on this chance. The strength of this method for analyzing problems in the social sciences is that it takes into account the time until an event takes place, i.e., the duration. More specifically, one calculates the likelihood that the event will occur in 'the next period' given the age (duration) of the entity under consideration (Greene, 1990).

Before turning to the empirical part of this thesis, this chapter attempts to answer the fourth sub-research question: How can event history analysis be helpful in providing better insight into the dynamics of firms? Thus, this chapter will briefly introduce the method of analysis which is used throughout the empirical part of this thesis, i.e., event history analysis. It will do this by explaining the basic and most important terms, models and characteristics of event history analysis. For a further econometric introduction into event history analysis see, for example, Greene (1990) or Blossfeld and Rohwer (1995).

The outline of this chapter is as follows. Section 3.2 provides an overview of the basic model and technique, and discusses the structure of the data input. Then, Section 3.3 deals with the technique by outlining possible variations on the basic model. Section 3.4 elaborates on this by addressing the most commonly used age dependency specifications. Section 3.5 deals with the model selection question. Section 3.6 explains the way to test the goodness of fit of event history models. Section 3.7 discusses the most important pitfalls of event history analysis. Finally, Section 3.8 summarizes this chapter. 


\subsection{Basic model, technique and data structure}

\subsubsection{Basic model}

Event history analysis is in fact a collection of methods, all with a common principle of analysis. This principle is the attempt to find the chance (and the variables that influence this chance) of an event occurring, whilst taking into account the duration until the event happens. In this, the event consists of some qualitative change that occurs at a specific point in time. In this thesis this event is, for example, the exit of an audit firm (Chapters 4 and 5), or the founding of a spinoff (Chapter 6). In its simplest form an event history is a longitudinal record of when events happened to a sample of individuals or collectivities (Allison, 1984).

The dependent variable in event history analysis is the hazard rate (Allison, 1984; Greene, 1990; Yamaguchi, 1991; Blossfeld and Rohwer, 1995). The hazard rate is the probability that an event will occur at a particular point in time to a particular individual or collectivity, given that the individual or collectivity is at risk at that time (i.e., is able to experience the event). In this thesis the collectivity is the group of auditors that makes up an audit firm. The hazard rate at a specific point in time is the probability that an audit firm will have an event given that it is still at risk, i.e., still in the market. For example, in Chapter 6 the hazard rate is the probability that an audit firm experiences a spinoff given that the audit firm is still in the market.

In analyzing changes, event history analysis is preferred above standard methods like classical (multiple) regression analysis for two reasons. First, event history analysis takes into account the duration until the event happens (Allison, 1984; Blossfeld and Rohwer, 1995). Classical regression methods can only use a dummy to indicate whether the event happened or not, and therefore they do not take into account any information about the length of duration preceding the event (Allison, 1984). If we take again the examples of Chapter 4 and 5 , event history analysis not only uses the information as to whether a firm experiences an exit, but also the time period the firm has been in existence, i.e., the longevity. Moreover, if the event did not take place in the observation period, then event history analysis still uses this observation by taking into consideration the duration until the observation period ends. This process is called censoring. ${ }^{1}$ Second, in contrast to standard methods, with event history analysis it is possible to calculate the chance that an event happens for every moment in time. This makes it possible to measure the effect of changing explanatory variables through time (Allison, 1984; Blossfeld and Rohwer, 1995). With standard regression techniques

1. All the observations that do not experience an event until the end of the observation period, are called censored data. 
the use of time-varying covariates (i.e., explanatory variables) with respect to measuring event histories (i.e., predicting time of an event) cannot be done satisfactorily. In explaining the exit rate of audit firms, event history analysis can, for example, incorporate the size of the audit firm at every moment in time as an explanatory variable.

\subsubsection{The technique}

Event history analysis models hazard rates (Yamaguchi, 1991). The hazard rate, $r(t)$, expresses the chance for an entity of having the event between time $t$ and $t+\Delta$, given that the event is still possible at time $t$. If $\mathrm{T}$ is a random variable with a continuous probability function $\mathrm{f}(\mathrm{t})$ for the duration of the risk period before an event, then the hazard rate is given as (Greene, 1990): ${ }^{2}$

$$
r(t)=\lim _{\Delta-0} \frac{\operatorname{Prob}(t \leq T \leq t+\Delta \mid T \geq t)}{\Delta},
$$

where

$$
\operatorname{Prob}(t \leq T \leq t+\Delta \mid T \geq t)
$$

indicates the probability that the event occurs during the duration interval $(t, t+\Delta)$ given that the event has not taken place for $t$ periods.

Further, we define the survival function $\mathrm{S}(\mathrm{t})$ as the function that indicates that $\mathrm{T}$ is at least larger than a certain value of $t$. Because we know that the cumulative probability of $t$ is

$$
F(t)=\operatorname{Prob}(T \leq t),
$$

we have

$$
S(t)=1-F(t)=\operatorname{Prob}(T \geq t) .
$$

2 In this sub-section the continuous model is considered as the basic model, because this model is used most frequently in research within the social sciences (see also Section 3.5). 
Therefore, it holds that the hazard rate is

$$
r(t)=\lim _{\Delta \rightarrow 0} \frac{F(t+\Delta)-F(t)}{\Delta S(t)} .
$$

Hence,

$$
r(t)=\frac{f(t)}{S(t)} .
$$

As already mentioned briefly before, the hazard rate of an event can be explained by incorporating a vector of (time-varying) explanatory variables $\mathrm{x}_{\mathrm{n}}$. This results in a hazard rate model like the following:

$$
r(t)=a+b_{n} x_{n},
$$

where $\mathrm{a}$ is a constant, $\mathrm{b}$ a vector of parameters and $\mathrm{n}$ the number of explanatory variables $\mathrm{x}$ included in the model. However, a problem with this specification is that the hazard rate $r(t)$ has to be equal or greater than zero, while the right-hand side of the equation can be any real number. This problem can be avoided by taking the logarithmic transformation of $\mathrm{r}(\mathrm{t})$ (Allison, 1984). This results in the following model:

$$
\log r(t)=a+b_{n} x_{n},
$$

or

$$
r(t)=A e^{b_{n} x_{n t}}
$$

In this way, $r(t)$ is the unobserved rate at which events occur, More specifically, $r(t)$ is the expected number of events in a time interval that is one unit long (Allison, 1984).

In order to estimate a hazard rate model, the use of maximum likelihood is often advocated because it yields efficient estimates in large samples (Allison, 1984; Greene, 1990). With maximum likelihood the parameters are estimated in such a way that they maximize the joint density of the observations. In practice the procedure amounts to the following. For each unit of time that each individual or collectivity is known to be at risk, a separate observational record is created. In this way, censored individuals or collectivities also contribute to the sample for all periods for which information is available about them. Then a dichotomous variable is added to these observational 
records that records whether an event takes place or not. Finally, these records are pooled, and a logit model is estimated for the dichotomous dependent variable using the method of maximum likelihood. As a result, this method can solve the problems of both censored data and time-varying explanatory variables (Allison, 1984). It produces estimates that are asymptotically unbiased, normally distributed and efficient (i.e., have minimum asymptotic sampling variance). This means that the properties hold as the sample gets larger (Allison, 1984; Tuma and Brandon, 1984).

\subsubsection{Data structure}

As mentioned in the previous sub-section, the data are structured on the basis of an individual or collectivity on the one hand and time periods of observation on the other hand (see also Chapter 2, Section 2.4). Every observation is called a spell. These spells together are the sample for the event history analysis. In every spell the starting time, the ending time, and the starting and ending state of the spell (to determine if there was an event) have to be given (Carroll, 1983; Blossfeld and Rohwer, 1995). In addition, (time-varying) covariates can be included in the data. When time-varying covariates are included, the spells are of the same length as between two observations of the covariates, making it possible to include all available information. In this thesis there are 9,652,10,563 and 2,929 usable spells for Chapter 4,5 and 6 , respectively. All these spells contain time-varying covariates, like the size of the firm at time $t$ and the density of the market at time $t-1$.

\subsection{Variations on the basic model}

\subsubsection{Discrete versus continuous}

In the previous section the continuous-time model was taken as the basic model. However, there are also discrete hazard rate models. In these models the hazard rate is the chance that the event will take place at time t, given that the event can still occur. ${ }^{3}$ In this case the hazard rate can be written as:

$$
P(t)=\operatorname{Prob}(T=t \mid T \geq t) \text {. }
$$

3 Note the difference with the continuous-time model (see Section 3.2.2 of this chapter). The hazard rate of the continuous model can be measured for every indefinitely small moment in time, whereas the hazard rate of the discrete model can only be measured at specific prespecified points in time. 
Therefore, in general, the explanatory discrete model looks like:

$$
P(t)=a+b_{n} x_{n t}
$$

However, because $\mathrm{P}(\mathrm{t})$ is a probability in the discrete model it needs to be between zero and one. Therefore, it is preferable to make a logit transformation of $\mathrm{P}(\mathrm{t})$ into:

$$
\log \left(P(t) /(1-P(t))=a+b_{n t} x_{n t}\right.
$$

Now $\mathrm{P}(\mathrm{t})$ varies between zero and one, while the left-hand side of the equation varies between minus and plus infinity (Allison, 1984). Discrete events can, unlike their continuous counterparts, only take place at specific pre-specified times (Petersen, 1993). The approval of the annual accounts of a firm is an example of such a discrete event. This event usually takes place every Spring.

\subsubsection{Parametric versus non-parametric}

Non-parametric models do not specify a specific shape of duration for the hazard rate (Blossfeld and Rohwer, 1995). Furthermore, with a non-parametric model, as opposed to a parametric model, the hazard rate is often not explained by incorporating covariates in the analyses (Yamaguchi, 1991). For social scientists models with covariates are clearly more interesting, because these models can also explain why certain hazard rates appear.

\subsubsection{Multiple episodes}

So far it has been assumed that individuals or collectivities can only experience one event. However, it is also possible that they experience an event more than once. For example, audit firms can have more than one spinoff during their existence (see Chapter 6). In general, however, the method of analysis for repeated events is not much different from that for single events (Allison, 1982). This is simply done by breaking up the spells in smaller ones, indicating in every spell whether an event has occurred or not.

\subsubsection{Multiple destinations}

Instead of experiencing one event more than once, an individual or collectivity (i.e., entity) can also experience one event out of a group of exclusive events. For example, an audit firm can leave the market through pure exit, through exit by diaspora or through exit by merger or acquisition (see Chapter 2, Section 2.5.3). These multiple destinations 
are used in Chapter 4 of this thesis. The hazard rate models can easily be adjusted for this by simply defining a separate hazard rate for each different kind of event (i.e., modeling competing risks) (Allison, 1982). Incorporating multiple destinations is usually done when it is expected that the covariates have different influences on the various possible events. Otherwise incorporating the various events as dummies is sufficient to make changes in the constant possible.

\subsection{Different age dependency specifications}

The shape of the hazard rate function is one of the key distinguishing features of the various event history models (Allison, 1984). A model can be independent, monotonic or nonmonotonic on duration: that is, constant, linear or nonlinear with duration in their age dependency. For example, the chance of a firm exiting the market can decrease with duration: so the longer a firm already exists, the less likely it is that this firm will exit. Hence, in these models the constant is changed in one that is dependent on duration.

In the remainder of this section some common used specifications are explained.

\section{Exponential model}

The exponential model is the simplest parametric model. It implies that the hazard rate is constant. So, in fact, there is no age dependency in this model. The general form of this model is as follows:

$$
r(t)=e^{a+b_{n r} x_{n t}},
$$

or

$$
r(t)=A e^{b_{n r} x_{n t}},
$$

where

$$
A=e^{a} \text {. }
$$

Therefore, in this model, the hazard rate to a particular event is the exponent of a constant and all other explanatory variables times their coefficient. 


\section{Gompertz model}

The Gompertz model is a monotonic model. It allows the log of the hazard rate to increase or decrease linearly with duration (Allison, 1984). The Gompertz model is formulated as:

$$
r(t)=A e^{c t} e^{b_{n} x_{m t}},
$$

where $\mathrm{c}$ is a constant.

\section{Weibull model}

The Weibull model is, just as the Gompertz model, a monotonic model. It allows the $\log$ of the hazard rate to increase or decrease linearly with the log of duration (Allison, 1984). The Weibull model is formulated as:

$$
\log r(t)=a+b_{n} x_{n t}+c \log t,
$$

which is:

$$
r(t)=A c^{t} e^{b_{n r^{x}}}
$$

\section{Cox regression}

The Cox model, also known as the proportional hazard model, is a generalization of the models described above. The model is formulated as:

$$
r(t)=a(t) e^{b_{n} x_{n t}},
$$

where $a(t)$ can be any function of duration (Allison, 1984). Because this function does not have to be specified, this model is often called partially or semi-parametric. In this way the data can determine the age dependence of the hazard rate (Yamaguchi, 1991). This model cannot be estimated by maximum likelihood, because restrictions have to be imposed on $a(t)$ when estimating b by maximum likelihood. Therefore, Cox invented a new method called partial likelihood (Allison, 1982). However, this model very much resembles maximum likelihood. Therefore, and because it is not used in the remainder of this thesis, this method is not further discussed here (for more details see Allison, 1984). 


\section{Piece-wise constant rate model}

Within the piece-wise constant rate model it is assumed that the hazard rates are piecewise constant, that is, constant within each interval of a set of time intervals but varying across intervals (Yamaguchi, 1991). In fact, this model is a specific variation of the exponential model. This method is especially helpful when there is no clear idea about the form of the age dependence of the process, or when certain-age dependent covariates cannot be measured explicitly (Blossfeld and Rohwer, 1995). The model looks like:

$$
r(t)=a e^{b_{n r} x_{n t}},
$$

where $\mathrm{a}_{1}$ is a constant coefficient associated with the l-th time period.

\subsection{Selecting a model}

When selecting a model, the first decision to make is whether a continuous or a discrete specification is more appropriate. If the data and the underlying process are both discrete in time, then a discrete model is most appropriate. If the data and the underlying process are both continuous in time, then a continuous model is most appropriate. If the data are discrete but the process is (reasonably well approximated by) a continuous process in time, then a continuous model is usually most appropriate. A continuous-time model is then used because the event is in reality (near to) a continuous process. As Carroll (1983, p. 427) observes about choosing a discrete model: 'Such reasoning allows the data to dictate the form of the model; ... Moreover, it is now being learnt that the use of discrete-time models for processes which occur continuously in time can lead, under not unusual circumstances, to erroneous inferences.' A further advantage of using a continuous-time model is that the estimation process for each event, in the case of multiple destinations, is the same as if there is only one event. So the other events are treated in the same way as the censored data (Allison, 1982). This implies that the hazard rate for all the different modes of exit can be calculated separately. All the observations with another destination state and all the observations that are actually censored, are treated as censored data. However, when taking the continuoustime model to estimate discrete data, the estimates may suffer from time-aggregation bias. This means that there is a gap between the duration of the real event and the recorded duration of the event, which is used in the analysis. The effect of this gap can, however, be minimized (see further Subsection 3.7.2). The combination of a discrete generating process and continuous data, is not possible. The data can never 
be more precise than the underlying process. For an overview of the choice of the model, see Table 3.1.

Table 3.1: Discrete versus continuous-time models

\begin{tabular}{|l|l|l|l|}
\hline \multicolumn{2}{|c|}{} & \multicolumn{2}{|c|}{ Process } \\
\cline { 3 - 4 } \multicolumn{2}{|c|}{} & Discrete & Continuous \\
\hline \multirow{3}{*}{ Data } & Discrete & Discrete model & Continuous model \\
\cline { 2 - 4 } & Continuous & Not possible & Continuous model \\
\hline
\end{tabular}

Because in this thesis the processes (exit and spinoff) are plausibly assumed to be continuous in time, whilst the data are discrete in time (an observation in approximately every two years), the most appropriate models to use are the continuous ones.

Once the choice between a discrete and a continuous-time model has been made, the detailed specification of the model needs to be chosen. This decision consists of two elements: the age dependency assumption and the use of simple or time-varying covariates. These choices can be based on theoretical insights and expectations regarding the subject at hand. With respect to age dependency, one has to decide upon the underlying relationship between the chance of the event and duration. This relation can take one of the following four forms. The chance of an event is: 1) independent of duration, 2) monotonic with duration, 3) non-monotonic with duration, or 4) not clearly related to duration. Table 3.2 provides an overview of the model which can be chosen in the four different situations.

Table 3.2: Applicable event history models for different assumed relationships between duration and event

\begin{tabular}{l|l}
\hline Assumed relationship & Examples of applicable models \\
\hline Process independent of duration & Exponential model \\
Process monotonic with duration & Gompertz or Weibull model \\
$\begin{array}{l}\text { Process non-monotonic with } \\
\text { duration }\end{array}$ & Cox regression or Piece-wise constant rate model \\
Age dependency unknown & Cox regression or Piece-wise constant rate model \\
\hline
\end{tabular}

With respect to the question whether or not to use time-varying covariates, the following holds. If theoretical insights or expectations suggest that changes in independent variables through time do influence the process, then these need to be included as time-varying covariates. 


\subsection{Test of goodness of fit}

To test the goodness of fit of a hazard rate model the likelihood ratio chi-square test statistic is usually an appropriate choice. This test is applicable whenever two models are nested, i.e., whenever one model is a special case of another model (Allison, 1984). The test statistic is constructed from a byproduct of maximum likelihood estimates, that is, from the maximized value of the log-likelihood function. The positive difference between two times the log-likelihood values is the test statistic. This statistic has a chi-square distribution in large samples, with the number of degrees of freedom equal to the difference of the number of constraints between the two models (Allison, 1984). With this information, tables of the chi-square distribution show whether the null hypothesis, predicting that the nested model is appropriate, can be rejected or not.

\subsection{Pitfalls of event history analysis}

Despite the fact that event history analysis is a very useful method to analyze events, there are also some drawbacks that should be kept in mind when using this method.

\subsection{1 (Unobserved) heterogeneity}

Instead of actual age dependence in the hazard rate it is also possible that (unobserved) heterogeneity in the data causes age dependence in an estimated model (Carroll, 1983). If there are differences between individuals or collectivities, which are not included in the model, then the hazard rate model will tend to reveal a declining relationship, even if the hazard rate is constant over duration for each individual or collectivity. The reason for this is that the group of individuals or collectivities with high hazard rates will experience early events, leaving the group of individuals or collectivities with small hazard rates in the process (Allison, 1984; Tuma and Brandon, 1984). However, it is extremely difficult to determine the real reason for a declining hazard rate. Whenever the sources of heterogeneity can be observed in terms of variables, it might be worthwhile to include these variables in the model. A way to deal with unobserved heterogeneity is to assume that this heterogeneity has a distribution (for instance, the gamma distribution), which can then be included in the model. Because this approach is not used in this thesis, it will not further be discussed here. For more information see, e.g., Blossfeld and Rohwer (1995). 


\subsubsection{Time aggregation bias}

Time aggregation bias occurs when discrete data are processed in a continuous way. A gap between the time when the event actually occurs and the time when the event is measured, causes a bias in the estimates. According to Petersen and Koput (1992), there is a solution for this estimation problem. They argue that the bias will be minimized when it is assumed that the event occurs in the first half of the interval. So, when the event happens between $t-1$ and $t$, it is optimal to assume that the event occurs between $t-1$ and $t-0.5$. The reason for this will not be further discussed here (for more details see Petersen and Koput, 1992).

\section{$3.8 \quad$ Summary}

This chapter provided an overview of the technique of event history analysis. Event history analysis calculates the chance of an entity experiencing an event, given that this entity can still experience the event. This conditional chance is called the hazard rate. Two main advantages of this technique are that it (i) takes into account the duration until the event happens, (ii) can incorporate (time-varying) covariates with respect to measuring event histories. Furthermore, the models are very flexible, being able to handle such things as different events and age dependency of a process. However, despite the great applicability of this method, one should also be careful about the pitfalls of event history analysis. 


\section{Chapter 4}

\section{Auditor Human CAPITAL AND AUdIT Firm SuRVIVAL}

Chapter 4 is the first empirical chapter of this thesis. It treats the first research question: How does human capital influence the survival chances of firms within the market? In answering this question, this chapter provides an overview of audit market research and a test of human capital theory. The latter has only recently been included in both industrial organization and organizational ecology studies.

[This chapter is a revised version of Bröcheler, Maijoor and van Witteloostuijn (1998)]

\subsection{Introduction}

The current structures of audit markets are the result of long-term processes of firm entry and exit, internal growth of firms, and inter-firm mergers and acquisitions. In these long-term processes, some audit firms appear to be more successful than others. Of the numerous small audit firms established in the past decades, most audit firms have exited the market while a few others survived and have become part of the large international networks (i.e., the Big Five ${ }^{1}$ ). This raises a twofold question: why are some audit firms more successful than other audit firms, and what makes a new audit firm a likely candidate for survival?

As auditing is a professional service, human capital can be expected to play a key role in the explanation of audit firm success and failure. In fact, many changes in the structure of the audit market as a result of entry, exit, internal growth, and merger and acquisition imply the regrouping of individual auditors without any substantial change in tangible assets. Therefore, this chapter will analyze the effects of two important components of human capital on audit firm performance. These two components are education (general human capital) and experience (specific human

1 The Big Five refers to the five largest international audit firms nowadays active in Dutch public practice. These are in alphabetical order: 1) Arthur Andersen, 2) Deloitte and Touche, 3) Ernst and Young, 4) KPMG, and 5) PriceWaterhouseCoopers. 
capital). More specifically, this chapter attempts to assess whether audit firm founders with high levels of education and experience are more successful than their less educated and experienced counterparts, and whether hiring more highly educated and more experienced auditors over time helps facilitating audit firm performance.

The motivation for this chapter is fourfold. First, this chapter extends existing audit market research by investigating the effects of audit firm characteristics on audit firm survival. Determinants of audit firm survival, which can be considered to be an important measure of audit firm performance, have seldom been analyzed explicitly in previous audit market research. Second, the chapter uses an alternative measure of the effects of auditor education and auditor experience. While there is a vast body of research on auditor education and auditor experience, most studies pertain to the consequences for decision making in specific auditing tasks. This chapter analyzes the effects of education and experience for a wider group of decisions, i.e., decisions about building up and managing an audit firm. Third, the chapter analyzes a part of the audit market neglected in previous audit market research, i.e., the small firm segment. Studying the process of entry, survival and exit of small firms adds to the understanding of the structures and dynamics of audit markets as a whole. Finally, from an organization sciences perspective, this chapter integrates organizational ecology and industrial organization by including variables that are used in both streams of research. Additionally, human capital theory is integrated into an organizational hazard rate model.

For the empirical analyses the Dutch audit market was selected. Many characteristics of the Dutch market are similar to those of the Anglo-Saxon audit markets covered in previous research (see, e.g., Gwilliam, 1987). For example, the Big Five international audit firm networks are all represented, dominating the Dutch market, and Dutch auditing and financial accounting regulations mirror international standards. The sample of the study consists of 1,695 firms that entered the Dutch audit market in the period 1930-1992. The year 1930 was taken as the first year of observation, because only from that time on the data set contained the necessary information regarding education. ${ }^{2}$ This resulted in a total of 9,652 spells.

This chapter is organized as follows. In Section 4.2 relevant previous research is discussed covering both audit market studies and organizational survival studies. In Section 4.3 the hypotheses of this study are formulated using human capital theory. Section 4.4 describes the specific characteristics of the data set and the variables used in the empirical tests. Section 4.5 discusses the specific characteristics of the event

2 Academic audit education in the Netherlands started at the Erasmus University in 1915. However, the auditors' association for academically educated auditors was founded in 1927 . and only from 1930 onwards membership lists of this association have been available. 
history model at hand. Section 4.6 reports the results of the study. Finally, Section 4.7 provides a discussion and appraisal of the study.

\subsection{Previous research}

In the past three decades, audit markets have been studied extensively. The existence of a dual market structure, with a few large audit firms (i.e., the Big Five) and a large number of small audit firms (i.e., the non-Big Five), has strongly influenced this area of research. For example, the effects have been studied of the dual market structure on competition, audit fees and audit quality (for an overview see, e.g., Yardley et al. 1992). Despite the extensive work done on the economic analysis of audit markets, at least three areas of research are underdeveloped. First, the determinants of audit firm success are rarely considered explicitly. Issues such as the performance effects of audit firm strategy, audit firm structure and audit firm human resource policy are not documented in the literature. One plausible reason for the existence of this gap is the lack of public data on many audit firm variables. One of the few areas of research that implicitly looks at audit firm characteristics and audit firm performance concerns auditor industry specialization (see, e.g., Craswell et al., 1995). The underlying theme in this area of research is that industry specialization of audit firms affects their performance by promoting a relatively high audit fee.

Second, while human capital is considered to be an important variable in auditing, it has rarely been studied in the context of audit market functioning. Of course, within audit judgment research, human capital, in the form of expertise, is a central issue of study. Education and experience, together with innate personal characteristics, are considered to be main elements of expertise (Bonner and Lewis, 1990). There have been many studies investigating the effects of elements of auditor expertise on auditor judgment (for overviews see, e.g., Choo, 1989; Davis and Solomon, 1989). However, most of these studies only considered the effects of expertise in specific auditing tasks like analytical review (see, e.g., Libby and Frederick, 1990), internal control evaluation (see, e.g., Mock and Turner, 1981), going-concern evaluations (see, e.g., Choo and Trotman, 1991) and audit planning (see, e.g., Christ, 1993). To our knowledge, no previous study has looked at the effects of expertise in terms of building up and managing an audit firm. Compared to audit judgment research, a benefit of studying human capital in the context of audit markets is the availability of relatively clear criterion variables. In this study, auditor expertise is linked to audit firm survival.

Third, nearly all audit market research focuses on the top-end of the market. Hence, so far, smaller audit firms have only rarely been the subject of audit market research. 
This is not justified considering the economic importance of the small audit client and small audit firm segment. Partly as a result of regulations, in Member States of the European Union the segment of smaller audit clients is large. For example, Maijoor (1994) documents the substantial economic effects of the Fourth EU Directive requiring the disclosure and audit of financial statements by small and medium-sized companies within the European Union. Smaller clients can be serviced both by large and small audit firms. Therefore, in this segment large audit firms are competing directly with small audit firms. In addition, anecdotal evidence suggests that smaller audit firms are frequently the target of acquisitions by the Big Five firms, so they are part of the growth strategies of the Big Five audit firms. Hence, both in the client market and in the market for the ownership and control of audit firms there are interactions between the Big Five firms and their non-Big Five counterparts.

In terms of theory, the majority of audit market studies are based on traditional industrial economics. Only few concepts are introduced from other perspectives looking at markets. For example, theories from organizational perspectives have rarely entered audit market research despite the possibility that they can contribute valuable insights on audit markets and audit firms. When taking into account theories from organization sciences, the evolution of market structures, and thus organizational survival, is one of the primary attention points of both industrial organization (IO) and organizational ecology $(\mathrm{OE})$. Both traditions share their interest in explaining the ups and downs in the history of industries and organizations (Boone and van Witteloostuijn, 1995). For explaining organizational survival both theories have recently incorporated human capital notions. The key argument is that survival chances of new firms increase with human capital features, in particular education and experience of the founders, owners, and/or employees. For example, Bates (1990) investigated this within an IO framework, Preisendörfer and Voss (1990) and Brüderl et al. (1992) from an OE point of view, and Boone and van Witteloostuijn (1996) combined both perspectives.

Nevertheless, the number of studies which have dealt with this issue is still limited. This is particularly true for the number of empirical studies in IO and OE. This chapter seeks to enrich our understanding of audit market evolution by exploring this human capital perspective in an IO - OE context. Theoretically, this implies a focus on the explanation of audit firm survival by incorporating human capital features. Empirically, this involves the application of event history techniques to analyze longitudinal firmlevel data. 


\subsection{Human capital hypotheses}

Human capital theory is, in empirical analyses, mainly used to explain earnings' levels and earnings' distributions. This chapter applies this approach to the firm level by considering the influence of measurable human capital features of the firm's founders and of the firm's auditors on its longevity and performance in the audit market.

Studies such as those of Bates (1990), Preisendörfer and Voss (1990), Brüderl et al. (1992), Boone and van Witteloostuijn (1996) and Pennings et al. (1998) confirm that organizational survival is facilitated by human capital features of the founders, owners and/or employees. All five studies make the well-established distinction between general and specific human capital. Here, the most important general human capital feature is (university) education, and the most important specific human capital feature is (industry or firm) experience. Human capital theory ascribes a positive influence to both these characteristics. Higher education of a founder, for example, has a positive influence on firm performance, and therefore on organizational survival. Similarly, more experience of a founder has a positive influence on firm performance, and therefore on organizational survival.

In addition, an effect during the lifetime of the audit firm is also assumed. Hence, an audit firm that hires more highly educated and more experienced auditors over time, can be expected to be more successful, and thus to live longer. The underlying argument is simply that education and experience both have a favorable impact upon the efficiency, effectivity and quality of the founders', owners' and/or employees' business-related behavior (for an extensive argument see, e.g., Pennings et al., 1998).

As yet, the predictions derived from human capital theory are very coarse-grained by focusing on survival per se. That is, the theory fails to take notice of a fine-grained differentiation by exit mode. The expected general positive relationship between better human capital features and longer organizational survival should be modified for the specific case of exit as a result of merger or acquisition (M\&A). Contrary to many other firm types, an audit firm is often seen as successful when one of the large (international) audit firm networks is interested in that particular firm. In audit firms, ownership and management are in the same hands. Therefore, a take-over of a smaller audit firm by a large audit firm can have two positive effects for the partner(s) of the acquired firm. First, the partner(s) of the smaller audit firm might become partner(s) of the large audit firm. Becoming partner of a large audit firm has a positive effect in terms of prestige and compensation (see, e.g., Bhamornsiri and Guinn, 1991). Second, instead of becoming partner of the bidding firm, the partner(s) of the target firm may decide to obtain cash for his/their ownership rights. This suggests that, when a distinction is made between different modes of exit, the relationships suggested by human capital theory should be modified for exit as a result of M\&A. 
As far as general human capital is concerned, we suggest therefore the following hypotheses as to the influence of education:

HIA: A higher level of education at the time of founding, and during the lifetime of an audit firm, increases survival chances of an audit firm.

H1B: A higher of education at the time of founding, and during the lifetime of an audit firm, decreases survival chances of an audit firm through exit by merger or acquisition.

Basically, the underlying argument is that high education contributes to an auditor's professional capabilities in terms of both the efficiency and quality of auditing behavior. Because of the positive influence that human capital theory subscribes to education, academic education can be expected to be valued higher than non-academic education. Higher education in this sense is defined as the percentage of auditors, either at founding or during the lifetime of the audit firm, who have an academic degree. So, firms with a higher education level are expected to be more successful as an independent audit firm, and thus to be associated with longer longevity. Alternatively, they are expected to be more attractive take-over candidates, thus being less likely to have increased longevity until exit by M\&A. Regarding the last point, Boone and van Witteloostuijn (1996) have tested the relationships suggested in human capital theory for the Dutch audit market for firms that entered in the 1970-1975 period. One of their findings is that firms with highly educated personnel at founding have higher mortality rates through M\&A. With a merger or acquisition, they argue, the new or acquiring firm can 'buy' a stock of highly educated auditors.

Note that all individuals included in the study are licensed auditors, which limits their variation in educational level. However, since 1915, there have been two educational routes to become auditor in the Netherlands. First, there is a program which can be attended while working in audit practice (i.e., a part-time study). Second, there is a program after obtaining an academic degree. We expect the academic route to result in a higher education level. For example, for a sample of 642 Dutch auditors Meuwissen (1998) found that academic auditors are more likely to become partners and advance faster towards partnership. In the US environment, several studies have confirmed a positive association between education level (i.e., MBA versus BA) and career advancement (see, e.g., Siegel, 1987; Wright, 1988; Alford et al., 1990; Bhamornsiri and Guinn, 1991; Siegel et al., 1992; and Spiceland, 1992). Apart from the internal route within a large firm, this career advancement may occur through M\&A. 
Regarding the influence of specific human capital, we introduce the following hypotheses as to experience:

$H 2 A$ : More experience at the time of founding, and during the lifetime of an audit firm, increases survival chances of an audit firm.

$H 2 B$ : More experience at the time of founding, and during the lifetime of an audit firm, decreases survival chances of an audit firm through exit by merger or acquisition.

The arguments underlying Hypotheses $2 \mathrm{~A}$ and $2 \mathrm{~B}$ resemble the rationales associated with Hypotheses $1 \mathrm{~A}$ and $1 \mathrm{~B}$. In terms of human capital, experience can be expected to contribute to such capabilities as attracting and sustaining client relationships, as well as building up and managing an audit firm. A firm headed by experienced founders, and with experienced personnel, is therefore viewed as better equipped to stay in the market or a more attractive take-over target. Through a merger or acquisition, the new or acquiring firm realizes a one-shot internalization of a bundle of new clients and managing capabilities. Experience is proxied by the mean of the total years of experience in public accounting of the auditors of the firm, either at founding or during the lifetime of the audit firm. So, firms with a higher experience level are, again, more likely to be successful in the audit market, or through longer survival until pure exit or through shorter survival until a merger or acquisition.

\subsection{The data and variables under study}

\subsubsection{The data}

The original database concerns the whole evolution of the Dutch audit market between 1880 and 1992 (see for a further description Chapter 2). ${ }^{3}$ For this study, however,

3 A number of other studies have also used this historical database of the Dutch audit profession. Maijoor et al. (1995) is a concentration study, providing a more detailed account of the construction of the original database. Maijoor and van Witteloostuijn (1996) use the data to apply the resource-based view of the firm to the evolution of the audit market and the odds of audit firm partners. Finally, Pennings et al. (1998) explore the database to study firm mortality. again in the context of the resource-based view of the firm. Compared to this chapter, their study uses less detailed data, without explicitly taking into account the different modes of exit. The similarity of this chapter's setup with Pennings et al. (1998) is rather weak. Pennings et al. (1998) is much more detailed as to the human/social capital variables, whereas this study is

(continued...) 
we start in 1930 , which was the year in which data on auditors with an academic education program was first available. In total, the research sample is based on 34 observation points in the period 1930-1992, containing 1,695 newly established audit firms that entered the audit market between 1930 and 1992 .

\subsubsection{Variables}

The dynamic database (see Chapter 2, Section 2.4), which is constructed to test Hypotheses 1 and 2, consists of the following explanatory variables for each established firm: (1) the percentage of academically educated founders at the time of founding of the firm, (2) the percentage of academically educated auditors during the lifetime of the firm ${ }^{4}$, (3) the mean of the years of experience of the founders at the time of founding of the firm, and (4) the mean of the years of experience of the auditors during the lifetime of the firm. It should be noted that the variables under (2) and (4) are time-varying, i.e., their values change during the lifetime of the audit firm. Furthermore, the variable under (2) is measured as the difference between the percentage of academically educated auditors during the lifetime of the firm and the percentage of academically educated founders of the firm. This variable is measured this way because simply taking the percentage would result in a multicollinearity problem with respect to the variables (1) and (2).

The control variables which are included in the empirical analyses can be divided into three groups (see also Figure 1.2 of Chapter 1). First, there are firm characteristics, other than human capital, which can be expected to affect longevity (see, e.g., Brüderl et al., 1992). These other firm characteristics are: (5) age of the firm; and (6) size of the firm. Both variables are time-varying. Second, there is the need to control for the influence of the market structure of the audit market (Delacroix et al., 1989; Hannan and Carroll, 1992). In doing this, the covariates are in fact one period lagged. The reason for this is that audit firms have to be able to respond to these (changing) characteristics of the market. These market structure variables are: (7) density (the number of existing firms in the market); (8) density squared ${ }^{5}$; $(9)$ concentration, $^{2}$

${ }^{3}$ (....continued)

much more refined in terms of the exit modes. Furthermore, the differences in the data's time window are considerable (1880-1990 vs. 1930-1992).

4 Both variables (1) and (2) are divided by 100 . This is done to make them more in range with the other variables.

5 Both variables (7) and (8) are divided by 100 . This is done to make them more in range with the other variables. 
measured by the $\mathrm{C}^{6}$; (10) the total number of entering firms at the time of founding of the audit firm; and (11) the total number of new auditors in the market at the time of founding of the audit firm. It should be noted that part of these market-level covariates are the subject of Chapter 5. Third, the influence of historical events during the period of study has to be taken on board (Pennings et al., 1998). These control variables are all included as dummy variables: (12) existence at the beginning of World War II; (13) the period after the establishment of the financial accounting law of 1970 (until 1983); and (14) the period after the establishment of the financial accounting law of 1983. The last two variables can be expected to have a positive influence on the survival chances of newly established audit firms because both laws substantially increased the demand for audit services (see, e.g., Maijoor and van Witteloostuijn, 1996).

The minimum value, maximum value, mean and standard deviation of the variables used in the empirical analyses are given in Table 4.1. Furthermore, Table 4.2 provides the correlation matrix for the variables used in the empirical analyses. Most correlations are low, and only few are slightly above 0.5 . Because of these satisfactory low levels, all variables are included in the empirical analyses. As indicated above, it should be noted that the level of education during the lifetime of the audit firm was measured as the marginal change in education level since the founding of the firm. The motivation for this measurement was that the correlation between education at founding and education during the lifetime of the audit firm was high.

The correlations that have a value above 0.5 concern, first, the experience level of the firm and the age of the firm. Unsurprisingly, older firms have, on average, auditors with more experience. Second, the higher correlations pertain to the concentration ratio on the one hand and the number of new auditors, World War II (negatively) and the Law of 1970 on the other hand. Also not unsurprisingly, density and density squared are highly correlated. In addition to this, both density and density squared are highly correlated with the number of new auditors and the law of 1983. Furthermore, high correlations exists between the number of new firms and the number of new auditors, and between the number of new auditors and the law of 1983. These high correlations are not an issue here, because they all relate to covariates that are entered into the analysis as a group. An important explanation for these higher correlations is that in the last decades of the period of study all these variables (except for the World War II dummy) attained higher levels.

6 Despite the presence of the Big Five in the audit industry, we selected the $\mathrm{C} 4$ as a control variable for the analyses. The reason for this is the historical importance of the Big Four in the Dutch audit market, i.e. in alphabetical order, 1) Coopers and Lybrand, 2) Deloitte and Touche, 3) KPMG, and 4) Moret Ernst and Young. 
CHAPTER 4: AUdTIOR HUMAN CAPITAL AND AUdIT FIRM SURVIVAL

Table 4.1: Statistic descriptives of the variables

\begin{tabular}{|c|c|c|c|c|c|}
\hline \# & Variable & Minimum & Maximum & Mean & $\begin{array}{r}\text { Standard } \\
\text { deviation }\end{array}$ \\
\hline & Longevity & 1 & 81 & 22.24 & 14.12 \\
\hline \multicolumn{6}{|c|}{ Panel A: basic model variables } \\
\hline 5 & Age (in years) & 0 & 80 & 11.32 & 11.47 \\
\hline 6 & Size (in auditors) & 1 & 516 & 4.04 & 21.08 \\
\hline 7 & Density/100 & 0.36 & 4.37 & 3.11 & 0.69 \\
\hline 8 & Density $2 / 100$ & 12.96 & 1909.69 & 1014.94 & 366.31 \\
\hline 9 & $\mathrm{C} 4$ & 9.07 & 49.38 & 25.74 & 13.44 \\
\hline 10 & Number of entrant firms & 2 & 255 & 66.59 & 55.33 \\
\hline 11 & Number of new auditors & 1 & 542 & 203.48 & 138.63 \\
\hline 12 & Existence at begin WWII & 0 & 1 & 0.31 & 0.46 \\
\hline 13 & $\begin{array}{l}\text { Dummy law } 1970 \\
\text { (until 1983) }\end{array}$ & 0 & 1 & 0.23 & 0.42 \\
\hline 14 & Dummy law 1983 & 0 & 1 & 0.17 & 0.38 \\
\hline \multicolumn{6}{|c|}{ Panel B: human capital variables } \\
\hline 1 & Education at founding/100 & 0 & 1 & 0.22 & 0.40 \\
\hline 2 & Change in education/100 & -1 & 1 & 0.01 & 0.18 \\
\hline 3 & Experience at founding & 0 & 41 & 3.17 & 5.80 \\
\hline 4 & Experience & 0 & 66 & 10.93 & 8.85 \\
\hline
\end{tabular}


Table 4.2: Correlation matrix of the variables included in the model

\begin{tabular}{|c|c|c|c|c|c|c|c|c|c|c|c|c|c|c|}
\hline \# & 1 & 2 & 3 & 4 & 5 & 6 & 7 & 8 & 9 & 10 & 11 & 12 & 13 & 14 \\
\hline 1 & 1 & & & & & & & & & & & & & \\
\hline 2 & -.29 & 1 & & & & & & & & & & & & \\
\hline 3 & -.01 & .01 & I & & & & & & & & & & & \\
\hline 4 & -.07 & .02 & .33 & 1 & & & & & & & & & & \\
\hline 5 & $=.12$ & .12 & -.15 & .58 & 1 & & & & & & & & & \\
\hline 6 & .01 & .03 & .11 & -.02 & .08 & 1 & & & & & & & & \\
\hline 7 & .08 & -.00 & .05 & -.01 & -.01 & .02 & 1 & & & & & & & \\
\hline 8 & .08 & .08 & .05 & .02 & -.03 & .02 & .96 & 1 & & & & & & \\
\hline 9 & .19 & .02 & .16 & -.00 & -.03 & .11 & .06 & .06 & 1 & & & & & \\
\hline 10 & -.05 & -.03 & -.02 & -.03 & -.07 & -.02 & .38 & .40 & -.21 & 1 & & & & \\
\hline 11 & .13 & -.01 & .11 & -.03 & -.07 & .07 & .50 & .53 & .52 & .62 & 1 & & & \\
\hline 12 & .17 & .06 & -.23 & .26 & .47 & .05 & -.16 & -.16 & -.52 & .14 & -31 & 1 & & \\
\hline 13 & .08 & .03 & .08 & .03 & .02 & .07 & -.17 & -.25 & .64 & -16 & .18 & -.28 & 1 & \\
\hline 14 & .14 & -.01 & .10 & -.05 & -.09 & .06 & .46 & .56 & 49 & .15 & .60 & -.29 & -.25 & 1 \\
\hline
\end{tabular}

\subsection{Event history analysis}

As explained in Chapter 3, the principle of event history analysis is the attempt to find causes for events by taking into account the time until the event happens. The event consists of some qualitative change that occurs at a specific point in time. In this chapter, the event is the exit of an audit firm from the market, and the hypothesized causes are the (changes in) human capital characteristics. Event history analysis is preferred above standard methods, like multiple regression analysis, for two reasons. First, event history analysis takes into consideration the time until the event happens. Second, in standard methods of analysis there is no satisfactory way of incorporating time-varying explanatory variables to study the duration until an event. In our study, the level of education and experience during the lifetime of the firm as well as firm and market variables are time-varying.

In this study, the hazard rate at a specific point in time is the probability that an audit firm will exit the market given that it is still at risk, i.e., still in the market. Besides the use of overall exit, we also make a distinction between four different modes of exit to be able to test the hypotheses on merger or acquisition. Here, the other modes 
of exit are tested side by side the group of exit by merger or acquisition to provide a more complete picture of the underlying processes. This implies that five different hazard rates are estimated: overall exit rate, pure exit rate, two M\&A exit rates, and diaspora exit rate (for a discussion of these modes of exit see Chapter 2, Section 2.5.3).

The particular method we use in this chapter is the exponential rate model (see Chapter 3, Section 3.4). We use this model because it is the simplest parametric model, i.e., it does not assume any age-dependency. Instead, we include age as a covariate (see Section 4.4.2). With estimating an exponential rate model we opt for a continuoustime specification, despite the fact that the data are measured on a discrete basis, i.e., about every two years (see Chapter 3, Section 3.5). The program we use to perform the analyses is called TDA, i.e., Transitional Data Analysis. This program is especially developed by Blossfeld and Rohwer to perform event history analyses (see Blossfeld and Rohwer, 1995). We use the program to estimate the vector of parameters by the method of maximum likelihood (Blossfeld and Rohwer, 1995). Furthermore, to diminish the negative effects of time aggregation bias (see Petersen and Koput, 1992, as well as Chapter 3, Section 3.7.2) we measured longevity until the end of the year of the last observation, so in the first half of the time interval.

\subsection{Results}

The results will be presented as follows. First, we provide an overview of the number of firms, and their characteristics, in the various modes of entry and the various modes of exit. Then, the results are given for the total hazard rate model, both excluding and including the human capital variables. Finally, the results are presented for the hazard rate models for each specific mode of exit. In these analyses the choice whether a merger is a big firm merger or a small firm merger is made based on whether or not the Big Four is involved. ${ }^{7}$

Table 4.3 provides the frequencies for the different modes of entry and the different modes of exit. In the period 1930-1992, a total of 1,695 firms entered the Dutch audit market. ${ }^{8}$ The pattern of frequencies suggests that the mode of entry is related to the mode of exit. Of all the firms that enter the market, the percentage of pure exits is far higher for pure entrants than for the other three modes of entry. Entrants by M\&A reveal a much higher percentage of exit by M\&A. Entries as a result of spinoffs have

7 Note that we performed sensitivity analyses which show that the results are robust for different coding rules regarding small and large firms (see Chapter 2, Section 2.5.3).

8 Note that we performed sensitivity analyses which show that the results are robust for different starting dates of the period of study. 
the highest percentage of survival until 1992. A reason for this could be that spinoffs are a fairly recent phenomenon (for more information, see Chapter 6). Finally, entrants by diaspora most frequently leave the market through pure exit.

Table 4.3: Frequencies of the different modes of entry and the different modes of exit

\begin{tabular}{|c|c|c|c|c|c|}
\hline Exit Entry & Pure entry & $\begin{array}{r}\text { Entry by } \\
\text { M\&A }\end{array}$ & $\begin{array}{r}\text { Entry by } \\
\text { spinoff }\end{array}$ & $\begin{array}{l}\text { Entry by } \\
\text { diaspora }\end{array}$ & Total entry \\
\hline Pure exit & $\begin{array}{r}625 \\
(50.7 \%)\end{array}$ & $\begin{array}{r}7 \\
(10.3 \%)\end{array}$ & $\begin{array}{r}87 \\
(24.7 \%)\end{array}$ & $\begin{array}{r}18 \\
(41.9 \%)\end{array}$ & 737 \\
\hline $\begin{array}{l}\text { Exit by M\&A } \\
(2 \text { non-Big } 4)\end{array}$ & $\begin{array}{r}264 \\
(21.4 \%)\end{array}$ & $\begin{array}{r}25 \\
(36.8 \%)\end{array}$ & $\begin{array}{r}87 \\
(24.7 \%)\end{array}$ & $\begin{array}{r}13 \\
(30.2 \%)\end{array}$ & 389 \\
\hline $\begin{array}{l}\text { Exit by M\&A } \\
\text { (Big 4/non-Big 4) }\end{array}$ & $\begin{array}{r}54 \\
(4.4 \%)\end{array}$ & $\begin{array}{r}7 \\
(10.3 \%)\end{array}$ & $\begin{array}{r}19 \\
(5.4 \%)\end{array}$ & $\begin{array}{r}2 \\
(4.7 \%)\end{array}$ & 82 \\
\hline $\begin{array}{l}\text { Exit by M\&A } \\
(2 \text { Big } 4)^{9}\end{array}$ & & $\begin{array}{r}2 \\
(2.9 \%)\end{array}$ & & & 2 \\
\hline Exit by diaspora & $\begin{array}{r}38 \\
(3.1 \%)\end{array}$ & $\begin{array}{r}10 \\
(14.7 \%)\end{array}$ & $\begin{array}{r}12 \\
(3.4 \%)\end{array}$ & $\begin{array}{r}3 \\
(7.0 \%)\end{array}$ & 63 \\
\hline $\begin{array}{l}\text { No exit by the } \\
\text { end of period }\end{array}$ & $\begin{array}{r}251 \\
(20.4 \%)\end{array}$ & $\begin{array}{r}17 \\
(25.0 \%)\end{array}$ & $\begin{array}{r}147 \\
(41.8 \%)\end{array}$ & $\begin{array}{r}7 \\
(16.3 \%)\end{array}$ & 422 \\
\hline Total & $\begin{array}{r}1232 \\
(100.0 \%)\end{array}$ & $\begin{array}{r}68 \\
(100.0 \%)\end{array}$ & $\begin{array}{r}352 \\
(100.0 \%)\end{array}$ & $\begin{array}{r}43 \\
(100.0 \%)\end{array}$ & 1695 \\
\hline
\end{tabular}

Table 4.4 contains descriptive statistics on the audit firms involved in the four modes of exit. The table shows some remarkable differences between the M\&A exits and the other modes of exit. On average, firms involved in M\&A with a Big Four firm are longer in the market, are larger at founding, and have a higher level of education at founding. In addition, the firms that disappear through M\&A with a Big Four audit firm are, on average, larger at exit. These results suggest indeed that being taken over by a Big Four firm is not an indication of poor performance. The results for experience are different: particularly, firms that exit by diaspora have the highest mean experience level at founding. It should be noted that t-test statistics regarding whether or not any of the differences between the different modes of exit are significant, show that this is not the case. The reason for this are the large reported standard deviations.

9 Because there were only two cases of a M\&A between two Big Four firms, this category is left out of the analyses. 
Table 4.4: Statistic descriptives of the different modes of exit

\begin{tabular}{|c|c|c|c|c|}
\hline & Pure exit & $\begin{array}{c}\text { Exit by M\&A } \\
(2 \text { non-Big } 4)\end{array}$ & $\begin{array}{c}\text { Exit by M\&A } \\
\text { (Big 4/non-Big 4) }\end{array}$ & Exit by diaspora \\
\hline \multicolumn{5}{|l|}{ Total } \\
\hline \multicolumn{5}{|l|}{ longevity } \\
\hline -Minimum & 1 & 1 & 1 & 1 \\
\hline -Maximum & 62 & 73 & 81 & 47 \\
\hline - Mean & 13.44 & 13.39 & 14.67 & 11.63 \\
\hline - Std.dev. & 12.14 & 13.41 & 15.12 & 12.39 \\
\hline \multicolumn{5}{|l|}{$\begin{array}{l}\text { Size at } \\
\text { founding }\end{array}$} \\
\hline - Minimum & 1 & 1 & 1 & 1 \\
\hline - Maximum & 48 & 56 & 202 & 48 \\
\hline - Mean & 1.17 & 2.17 & 11.20 & 2.54 \\
\hline - Std.dev. & 1.85 & 4.82 & 33.71 & 5.95 \\
\hline \multicolumn{5}{|l|}{ Size at exit } \\
\hline -Minimum & 1 & 1 & 1 & 2 \\
\hline -Maximum & 70 & 68 & 233 & 47 \\
\hline -Mean & 1.37 & 3.46 & 15.35 & 4.16 \\
\hline - Std.dev. & 4.15 & 6.70 & 40.63 & 6.39 \\
\hline \multicolumn{5}{|l|}{ Education of } \\
\hline \multicolumn{5}{|l|}{ founders } \\
\hline - Minimum & 0 & 0 & 0 & 0 \\
\hline - Maximum & 1 & 1 & 1 & 1 \\
\hline - Mean & 0.16 & 0.26 & 0.27 & 0.21 \\
\hline - Std.dev. & 0.35 & 0.41 & 0.40 & 0.36 \\
\hline \multicolumn{5}{|c|}{$\begin{array}{l}\text { Experience of } \\
\text { founders }\end{array}$} \\
\hline -Minimum & 0 & 0 & 0 & 0 \\
\hline - Maximum & 41 & 38 & 25 & 20.5 \\
\hline - Mean & 3.46 & 3.78 & 4.63 & 4.79 \\
\hline - Std.dev. & 6.89 & 6.25 & 5.77 & 5.91 \\
\hline
\end{tabular}

The exponential rate model is estimated for two main models. The first model (Model 1) focuses on undifferentiated (i.e., overall) exit and the second variant distinguishes the four modes of exit (Models $2 \mathrm{a}$ to 2d), namely pure exit, exit by M\&A of two non-Big Four firms, exit by M\&A of a non-Big Four and a Big Four firm, and exit by diaspora.

In Table 4.5, the results are presented for the overall hazard rate model (i.e., for the complete sample of entrants). 
Table 4.5: Coefficient estimates and standard errors (in parentheses) of the exponential model for the whole sample

\begin{tabular}{|c|c|c|c|c|c|}
\hline \multirow{2}{*}{\multicolumn{2}{|c|}{$\begin{array}{l}\text { \# Variable } \\
\text { Panel A: basic model variables }\end{array}$}} & \multicolumn{2}{|c|}{$\begin{array}{l}\text { Model la: } \\
\text { Total hazard rate without } \\
\text { human capital variables }\end{array}$} & \multicolumn{2}{|c|}{$\begin{array}{c}\text { Model lb: } \\
\text { Total hazard rate with } \\
\text { human capital variables }\end{array}$} \\
\hline & & & & & \\
\hline & Constant & -3.4040 & $(0.3949)^{* * *}$ & -3.5694 & $(0.3969)^{* * *}$ \\
\hline 5 & Age of the firm & 0.0190 & $(0.0028)^{* * *}$ & 0.0073 & $(0.0038)^{*}$ \\
\hline 6 & Size of the firm & -0.0050 & $(0.0022)^{* * *}$ & -0.0035 & $(0.0020)^{*}$ \\
\hline 7 & Density/100 & 0.5500 & $(0.2500)^{* *}$ & 0.5825 & $(0.2494)^{* *}$ \\
\hline 8 & Density $^{2} / 100$ & -0.0010 & $(0.0005)^{* * *}$ & -0.0010 & $(0.0005)^{* *}$ \\
\hline 9 & $\mathrm{C} 4$ & -0.0035 & $(0.0087)$ & -0.0024 & $(0.0088)$ \\
\hline 10 & Number of entrant firms & 0.0013 & $(0.0012)$ & 0.0009 & $(0.0012)$ \\
\hline 11 & Number of new auditors & 0.0004 & $(0.0006)$ & 0.0006 & $(0.0006)$ \\
\hline 12 & Existence at begin WWII & -0.5452 & $(0.0900)^{* * *}$ & -0.5231 & $(0.0903)^{* * * *}$ \\
\hline 13 & Law 1970 (until 1983) & -0.2037 & $(0.1979)$ & -0.2353 & $(0.1993)$ \\
\hline 14 & Law 1983 & -0.0933 & $(0.2197)$ & -0.1098 & $(0.2205)$ \\
\hline \multicolumn{6}{|c|}{ Panel B: human capital variables } \\
\hline 1 & Education at founding/100 & & & -0.2560 & $(0.0802)^{* * *}$ \\
\hline 2 & Change in education $/ 100$ & & & -0.2379 & $(0.0017)$ \\
\hline 3 & Experience at founding & & & -0.0017 & $(0.0055)$ \\
\hline 4 & Experience & & & 0.0230 & $(0.0043)^{* * *}$ \\
\hline
\end{tabular}

Panel C: statistics

Log likelihood only constant $-4629.5880$

Log likelihood basic model

Log likelihood total model

Likelihood ratio test statistic

$79.181^{* * *}$

$50.7854^{* * * *}$

Significance (two-tailed): ${ }^{*} \mathrm{p}<.10,{ }^{* *} \mathrm{p}<.05$, and ${ }^{* * *} \mathrm{p}<.01$.

First, a model with only the control variables is estimated (panel A). Subsequently, the human capital variables are added to the basic model (panel B). In panels A and $B$, the estimates of the coefficients and their standard errors are presented. Further down in the table, the log likelihood of the models are provided together with the $\mathrm{X}^{2}$-statistic of the likelihood ratio test (panel C) (see also Chapter 3, Section 3.6). The likelihood ratio test statistics at the bottom of the table reveal that Model la gives a significantly better explanation of the longevity of audit firms than a constant hazard 
rate model (i.e., a model with only a constant). Furthermore, it shows that Model $1 \mathrm{~b}$, i.e., the model with the human capital variables, gives a significantly better explanation of the longevity of audit firms than Model 1a, i.e., a model with only the control variables. Because the hazard rate, or the mortality rate, is the dependent variable in the models, the sign of the coefficients is just the opposite to the one where the longevity of an audit firm until exit is considered.

As the results for the two Models 1a and $1 \mathrm{~b}$ show, the signs and significance levels for the control variables are stable between the two models. The two firm characteristics, age and size, have both a significant effect on firm survival. For the complete sample, a higher age increases the chance of exit, and a bigger size decreases the chance of exit. About the effect of age we can remark the following. The many small firms within this study's time window are likely to have influenced the effect. The reason for this is that the odds of small firms (particularly single proprietorships) are inextricably bound up with the fate of the individual auditors. For example, a single proprietorship will exit the market with the retirement (or death) of the owner-auditor. Furthermore, the analyses with respect to the different modes of exit later on in this chapter will show that the effect of age is in fact a combined effect. Therefore, it could be interesting to let the effect of age vary, i.e., to incorporate age dependency in a model. The effect of size can be explained by the fact that bigger firms are usually stronger and more successful. Furthermore, when firms are performing badly, it is more common that they first will downsize, before leaving the market, than that they exit the market when they are still large. Of the market structure variables, only density per se and density squared have a significant effect. There is a positive decreasing effect of the number of firms in the market on the likelihood of exit. A reason for this could be that there has not been a legitimation process in the Dutch audit industry. Furthermore, the fact that the relationship is decreasing probably has to do with the developments in the last three decades, i.e., increasing demand at high density (see also Chapter 5, Section 5.5). The estimates of the three other market structure covariates - $\mathrm{C} 4$, number of entrant firms and number of new auditors - fail to produce significant findings. Of the historical events, there is only a significant positive effect of the dummy regarding the existence at the beginning of World War II. This unexpected result can (partly) be explained by the demand for audit services by the German regime during World War II (see Chapter 2, Section 2.2.3). Furthermore, measurements were done before and after the war, but not during the war. Therefore, the dummy indicates that, compared to a period of normal competition, firms that were active before the war, were also active after the war. Finally, neither the 1970 law nor the 1983 regulation dummy generate significant estimates in these analyses.

Regarding the human capital variables (Model 1b), the effects of education and experience vary. A higher level of education at founding reduces the chances of exit, 
while a higher level of experience during the lifetime of an audit firm increases the chances of exit. The effects of the other two human capital variables are not significant. So, the undifferentiated event history analysis produces evidence for Hypothesis $1 \mathrm{~A}$ with respect to education at founding and runs counter to Hypothesis $2 \mathrm{~A}$ with respect to experience through time.

A clear limitation of the models in Table 4.5 is that they do not distinguish between the various modes of exit. However, as argued earlier, the audit firm performance interpretations of the four exit events may be rather different from each other. Therefore, Table 4.6 reports the results of the simultaneously estimated differentiated hazard rates. In the discussion of the results of Table 4.6, we will especially focus on the two M\&A exit rates in relation to the pure exit rate, because they relate to Hypotheses $1 \mathrm{~B}$ and $2 \mathrm{~B}$.

The log likelihoods at the bottom of the table, again, reveal that the model with the different exit modes gives a significantly better explanation of the longevity of audit firms than a constant hazard rate model, i.e., a model with only a constant. The significance level is calculated using a likelihood ratio test (see Chapter 3, Section 3.6).

A striking result of these differentiated models is that the signs of the coefficients for the model for pure exit are nearly all opposite to the signs of the coefficients in the two M\&A models. This suggests that, in accordance with the hypotheses, the exit rates should be treated differently in terms of firm performance. A long period until pure exit can be considered to be an indicator of good audit firm performance, but the same holds true for the case where the period until exit through M\&A is short.

Regarding the human capital variables, given in Panel B, the results indicate that education has a positive effect on firm performance. Education at founding and an increasing level of education during the lifetime of the audit firm decrease the likelihood of pure exit. In addition, increasing levels of education during the lifetime of the audit firm significantly increase the chance of a take-over by a Big Four audit firm. The results for experience at founding and experience during the lifetime of an audit firm vary. The results suggest that experience at founding has a positive effect on firm performance: either the period until pure exit is lengthened, or the period until M\&A is exit shortened. However, the results indicate that experience during the lifetime of the firm has a negative effect on performance: either the period until pure exit is shortened, or the period until M\&A exit is lengthened. Furthermore, experience at founding increases the chance of exit by diaspora.

Of the control variables, more covariates are significant at the level of specific modes of exit than at the level of total exit. In addition, the effect of most control variables for pure exit resemble those for total exit. This can be expected as pure exit is the largest 
Table 4.6: Coefficient estimates and standard errors (in parentheses) of the exponential model for the different modes of exit

\begin{tabular}{|c|c|c|c|c|c|}
\hline \# & Variable & \multicolumn{2}{|c|}{$\begin{array}{l}\text { Model } 2 \mathrm{a} \text { : } \\
\text { Hazard rate for pure exit }\end{array}$} & \multicolumn{2}{|c|}{$\begin{array}{c}\text { Model } 2 \mathrm{~b}: \\
\text { Hazard rate for exit by } \\
\text { M\&A (2-non Big 4) }\end{array}$} \\
\hline \multicolumn{6}{|c|}{ Panel A: basic model variables } \\
\hline & Constant & -6.0069 & $(0.8544)^{* * *}$ & -3.6738 & $(0.5047)^{* * *}$ \\
\hline 5 & Age of the firm & -0.0213 & $(0.0071)^{* * *}$ & 0.0393 & $(0.0056)^{* * *}$ \\
\hline 6 & Size of the firm & -0.1253 & $(0.0336)^{* * *}$ & -0.0078 & $(0.0044)^{*}$ \\
\hline 7 & Density/100 & 2.4189 & $(0.5358)^{* * *}$ & -0.6993 & $(0.3282)$ \\
\hline 8 & Density ${ }^{2} / 100$ & -0.0041 & $(0.0009)^{* * *}$ & 0.0013 & $(0.0007)^{*}$ \\
\hline 9 & $\mathrm{C} 4$ & -0.0445 & $(0.0128)^{* * *}$ & 0.0419 & $(0.0147)^{* * *}$ \\
\hline 10 & Number of entrant firms & -0.0025 & $(0.0016)$ & 0.0034 & $(0.0024)$ \\
\hline 11 & Number of new auditors & 0.0024 & $(0.0008)^{* * *}$ & -0.0010 & $(0.0011)$ \\
\hline 12 & Existence at begin WWII & -0.2701 & $(0.1139)^{* *}$ & -0.9632 & $(0.1799)^{* * *}$ \\
\hline 13 & Law 1970 (until 1983) & 0.4060 & $(0.2803)$ & -0.8970 & $(0.3385)^{* * *}$ \\
\hline 14 & Law 1983 & 0.6632 & $(0.3157)^{* *}$ & -1.1755 & $(0.3819)^{* * *}$ \\
\hline \multicolumn{6}{|c|}{ Panel B: human capital variables } \\
\hline 1 & Education at founding/100 & -0.5307 & $(0.1120)^{* * *}$ & 0.0812 & $(0.1354)$ \\
\hline 2 & Change in education $/ 100$ & -0.5603 & $(0.0028)^{* *}$ & -0.1592 & $(0.0025)$ \\
\hline 3 & Experience at founding & -0.0268 & $(0.0088)^{* * *}$ & 0.0299 & $(0.0089)^{* * *}$ \\
\hline 4 & Experience & 0.0596 & $(0.0071)^{* * *}$ & -0.0348 & $(0.0077)^{* * *}$ \\
\hline
\end{tabular}

Panel C: statistics

Log likelihood only

constant

Log likelihood basic model

Log likelihood total model

Likelihood ratio test statistic

Significance (two-tailed): ${ }^{*} \mathrm{p}<.10,{ }^{* *} \mathrm{p}<.05$, and ${ }^{* * *} \mathrm{p}<.01$.

mode of exit. Therefore, we will discuss only the differences with the total exit rate model. First, as far as the firm characteristics are concerned, age either decreases the chances of pure exit or increases the chances of M\&A exit. Hence, age has a positive effect on firm performance. Of the market characteristics, concentration now has a significant effect: there is a smaller chance of pure exit and an increased chance of an M\&A exit. Further, the number of new auditors has a negative effect on survival 
Table 4.6 (continued): Coefficient estimates and standard errors (in parentheses) of the exponential model for the different modes of exit

\begin{tabular}{|c|c|c|c|c|c|}
\hline \multirow{2}{*}{\multicolumn{2}{|c|}{$\begin{array}{l}\text { Variable } \\
\text { Panel A: basic model variables }\end{array}$}} & \multicolumn{2}{|c|}{$\begin{array}{c}\text { Model 2c: } \\
\text { Hazard rate for exit by } \\
\text { M\&A (Big 4/non-Big 4) }\end{array}$} & \multicolumn{2}{|c|}{$\begin{array}{c}\text { Model } 2 \mathrm{~d} \text { : } \\
\text { Hazard rate for exit by } \\
\text { diaspora }\end{array}$} \\
\hline & & & & & \\
\hline & Constant & -6.0330 & $(1.4014)^{* * *}$ & -5.7010 & $(1.2354)^{* * *}$ \\
\hline 5 & Age of the firm & 0.0468 & $(0.0121)^{* * *}$ & 0.0114 & $(0.0148)$ \\
\hline 6 & Size of the firm & 0.0015 & $(0.0025)$ & -0.0042 & $(0.0074)$ \\
\hline 7 & Density/100 & -0.1481 & $(0.8644)$ & -0.6616 & $(0.7500)$ \\
\hline 8 & Density ${ }^{2} / 100$ & 0.0004 & $(0.0017)$ & 0.0010 & $(0.0016)$ \\
\hline 9 & $\mathrm{C} 4$ & 0.0420 & $(0.0338)$ & 0.0512 & $(0.0388)$ \\
\hline 10 & Number of entrant firms & 0.0037 & $(0.0060)$ & -0.0057 & $(0.0070)$ \\
\hline 11 & Number of new auditors & -0.0032 & $(0.0027)$ & 0.0028 & $(0.0027)$ \\
\hline 12 & Existence at begin WWII & -1.8766 & $(0.4632)^{* * *}$ & -0.0983 & $(0.4752)$ \\
\hline 13 & Law 1970 (until 1983) & -1.1147 & $(0.7838)$ & -1.3027 & $(0.9250)$ \\
\hline 14 & Law 1983 & -0.1658 & $(0.8024)$ & -1.0670 & $(0.9617)$ \\
\hline \multicolumn{6}{|c|}{ Panel B: human capital variables } \\
\hline 1 & Education at founding/100 & 0.3354 & $(0.2893)$ & -0.2972 & $(0.3528)$ \\
\hline 2 & Change in education $/ 100$ & 1.3306 & $(0.0049)^{* * *}$ & 0.1050 & $(0.0066)$ \\
\hline 3 & Experience at founding & 0.0273 & $(0.0182)$ & 0.0440 & $(0.0206)^{* *}$ \\
\hline 4 & Experience & -0.0176 & $(0.0161)$ & -0.0299 & $(0.0194)$ \\
\hline
\end{tabular}

Panel C: statistics

Log likelihood only constant $-5920.7382$

Log likelihood basic model

Log likelihood total model

Likelihood ratio test statistic

$327.3162^{* * * *}$

$157.1194 * * *$

Significance (two-tailed): ${ }^{*} \mathrm{p}<.10,{ }^{* *} \mathrm{p}<.05$, and ${ }^{* * *} \mathrm{p}<.01$.

until pure exit. Of the historical events, the specific models are (partially) also significant with respect to the two financial accounting laws. Both laws had a negative effect on firm performance by decreasing the chance of survival until pure exit (for the law of 1983), and by decreasing the chance of being taken over by another audit firm (both for the 1970 law and the 1983 law). A reason for this result could be that the assumption that more demand simply decreases the exit rates of audit firms, is not correct. The increase in demand as a result of the laws could also at the same time have stimulated people to establish new audit firms. This results in more dynamics 
within the market, and it could therefore even increase exit rates. Further on in this thesis, the results of Chapter 6 also support this dynamics idea by an increased chance of a spinoff as a result of the Law of 1983 .

Overall, the set of results is very complicated indeed, with mixed evidence in favor of and against the hypotheses. Clearly, the estimates indicate that the pure and M\&A exit modes must be treated differently. For example, the signs of the coefficients for the pure exit model are nearly all opposite to the signs of the coefficients in the two M\&A models (eight (Model 2b) or nine (Model 2c) of the eleven control variables, and three (Model 2b) or four (Model 2c) of the four human capital variables).

\subsection{Conclusion and discussion}

This chapter has analyzed the effects of human capital on audit firm survival, which is an important measure of audit firm performance. Four categories of human capital were distinguished: general human capital (education) and specific human capital (experience), human capital at founding and human capital during the lifetime of the audit firm. Additionally, various modes of exit of audit firms were distinguished, including pure exit and exit as a result of merger and acquisition. The hypotheses were tested with a longitudinal database of the Dutch audit industry, by applying sophisticated event history analysis techniques that allow including time-varying independents in studying the duration until exit. There are two main results of this chapter. First, the findings suggest, indeed, that human capital variables are important determinants of audit firm performance. This holds true for all four categories of human capital identified. Second, the results suggest that, with respect to performance, the various modes of exit should be treated differently. In the case of pure exit, a long period until exit is preferred, while in the case of exit by M\&A, a short period points at superior performance.

The specific results regarding the influence of the level of education on the longevity of audit firms are the following. In general, a higher education level, either at founding or during the lifetime of the audit firm, has a positive effect on the longevity of the firm until pure exit. This positive effect is absent in the case of exit as a result of M\&A. As indicated in Section 4.3, the positive influence of education on longevity until pure exit from the market provides an indication of a higher performance of these firms relative to audit firms with less educated auditors. The fact that there is no positive influence of education on longevity until exit by M\&A can be explained as follows. While education increases the performance of audit firms, it makes them also more attractive take-over candidates, which decreases their longevity. The results are in line with the suggestion that a higher education level increases the performance 
of the audit firm: either the firm has a higher chance of survival or the firm has a higher chance of an M\&A exit.

The main results regarding the influence of previous experience on the longevity of audit firms are the following. On the one hand, experience at founding has a positive influence on the longevity of the audit firm until pure exit, and a negative influence on the longevity until M\&A exit. Hence, experience at founding has a positive effect on audit firm performance. On the other hand, higher experience levels during the lifetime of the audit firm, i.e., the aging of the personnel of the firm, has a negative effect on audit firm performance. The aging of personnel during the lifetime of the firm decreases survival chances until pure exit, and reduces chances of becoming a take-over target.

Table 4.7 classifies our key findings by reporting the overall association between the audit firm human capital features on the one hand and the audit firm events on the other hand. For the sake of the argument, we have reversed the results, so that the influence on the survival rate is reported.

Overall, the pattern of our results suggest the following typology of audit firm exit.

1) The retirement destiny. The pure exit event analyses reach significance for all four human capital features: education at founding, education over time and experience at founding are positively associated with prolonged survival, whilst experience over time is negatively correlated with the survival rate. At founding, the mean levels of education ( 16 percent academics) and experience ( 3.46 years) are low. The mean life duration is 13.44 years. All this together seems to indicate that the pure exit case pertains to the marginal audit firms in the market's fringe. That is, the low educated auditor has developed experience over time after establishing a small audit firm until the date of exit. Probably, in many cases exit occurs as a result of retirement. With this interpretation, pure exit is anything but a measure of success. Rather, in many cases, this route is taken for want of anything better.

2) The experience trap. The small firm merger case is associated with non-significant education parameters estimates. Both experience coefficients are significant, however. Experience at founding is negatively associated with the survival rate, whereas a positive linkage is observed for the experience over time proxy. In absolute terms, the mean level of education at founding ( 26 percent academics) is at the high end, whereas the mean founding experience level (3.78 years) is at the low end. Mean longevity is 13.39 years. An interpretation of these results may be that the auditors 
Table 4.7: A summary through an audit firm exit typology

Audit firm event

\begin{tabular}{|c|c|c|c|c|c|}
\hline Audit firm feature & Total exit & Pure exit & $\begin{array}{l}\text { Small firm } \\
\text { merger }\end{array}$ & $\begin{array}{l}\text { Big firm } \\
\text { acquisition }\end{array}$ & $\begin{array}{l}\text { Diaspora } \\
\text { resolution }\end{array}$ \\
\hline Education at founding & $(+)$ & $(+)$ & NS & NS & NS \\
\hline Education over time & NS & $(+)$ & NS & $(-)$ & NS \\
\hline Experience at founding & NS & $(+)$ & $(-)$ & NS & $(-)$ \\
\hline Experience over time & $(-)$ & $(-)$ & $(+)$ & NS & NS \\
\hline $\begin{array}{l}\text { Mean education at } \\
\text { founding (in \%) }\end{array}$ & & 16 & 26 & 27 & 21 \\
\hline $\begin{array}{l}\text { Mean experience at } \\
\text { founding (in years) }\end{array}$ & & 3.46 & 3.78 & 4.63 & 4.79 \\
\hline Mean longevity & & 13.44 & 13.39 & 14.67 & 11.63 \\
\hline Audit firm type & & $\begin{array}{c}\text { Retirement } \\
\text { destiny }\end{array}$ & $\begin{array}{c}\text { Experience } \\
\text { trap }\end{array}$ & $\begin{array}{l}\text { Education } \\
\text { acquisition }\end{array}$ & $\begin{array}{l}\text { Career } \\
\text { move }\end{array}$ \\
\hline
\end{tabular}

Note: An NS indicates a non-significant, a plus (+) a positive and a minus (-) a negative association with the survival rate.

involved are caught into an experience trap: after establishing a rather small audit firm, they were not targeted as an attractive take-over candidate by a Big Four firm, but rather stayed where they were, without producing a substantial growth rate, until they were forced to merge. This route is therefore anything but a measure of success.

3) The education acquisition. The big firm acquisition event reveals only one significant effect: the firm's survival rate is negatively associated with education over time. The absolute mean levels of education ( 27 percent academics) and experience ( 4.63 years) at founding are relatively high. Additionally, the target firms witness the longest mean longevity of 14.67 years. This suggests that the big firm buys the stock of highly educated auditors that the medium-sized firm has developed over a prolonged period of time. From the target firm's perspective, this is a measure for success. By building up an educational asset bundle over time, the medium-sized firm develops into an attractive take-over candidate fo- the big market leaders. Through this route, the target firm's auditors advances their careers by entering into the career ladder of a big rival. This entry into the internal labor market of a big audit firm is surely regarded as a manifestation of professional success. 
4) The career move. The diaspora resolution event is linked to a single significant finding: exit through diaspora is negatively associated with experience at founding. In terms of mean experience at founding, the diaspora firms are ranked first (4.79 years), with the mean education level at founding being at the low end ( 21 percent academics). Moreover, mean longevity is the lowest with 11.63 years. Probably, the diaspora history reflects a career move. That is, highly experienced auditors apparently start a new, rather small, audit firm to build up a reputation over time that opens up opportunities to climb up the professional career ladder after a prolonged period of substantial growth. Contrary to the big firm acquisition case, the diaspora firm is not viewed as an attractive takeover target by the Big Four because the diaspora firm is (i) on average too small, and (ii) does not stand out for its education stock. So, by the end of the day, the highly experienced diaspora auditors advance their individual careers by all taking their own road to success.

Of course, our typology is tentative only. For one, future research may focus on disentangling the processes that underlie this rough classification, since many of the suggestive interpretations are testable by focusing on auditor-level career data. For example, what happens to the partners of the medium-sized firms that are acquired by a Big Five market leader? Additionally, the typology may be brought to perfection by introducing other and/or fine-grained variables. For instance, what is the influence of the partner-associate distinction that is so dominant in the audit industry, and what explains the different growth (and decline) paths of audit firms?

The bottom line is that the audit industry is an intriguing mixture of a labor and product market. Much of what happens at the supply side of the product market in terms of firm-level events, is inextricably bound up with career motives at the supply side of the labor market. On the one hand, that is, a key driver of the industry's competitive processes is the human capital development within the industry as a whole and across audit firm types. By the end of the day, the dominant production factor of an audit firm is the human capital embodied in the firm's auditor associates and partners. Here, the analyses may be pushed further by introducing additional human capital features. In this context, for example, the argument of Pennings et al. (1998) that audit firm performance may well be explained by a firm's bundle of auditor client network linkages is worthwhile exploring. On the other hand, much of what happens to an audit firm, is a direct consequence of the professional career motives of the firm's auditors. Our key argument is, perhaps, that a large part of the interpretation of the different audit firm events must rest on career arguments. As argued above, this opens up a large array of avenues for future research. In any case, these and other questions indicate the challenging nature of the study of audit industries along the lines suggested in this chapter. 



\section{Resource Partitioning Processes and Audit Firm Survival}

Chapter 5 is the second empirical chapter of this thesis. It relates to the second research question: How does the interaction between market concentration and firm size influence the survival chances of firms within the market? In answering this question, this chapter provides a test of the resource partitioning theory for a professional service market.

[This chapter is a revised version of Boone, Bröcheler and Carroll (1999)]

\section{$5.1 \quad$ Introduction}

After almost 15 years of use in explaining the rise of specialist organizations in markets dominated by large-scale efficient producers, organizational ecology's theory of resource partitioning now occupies a familiar but unsettled scientific status. As a general theory with replicated empirical support, it is commonly regarded as sound and useful; the theory is used by organizational analysts in a wide variety of disparate contexts. The difficulty rests with uncertainty over its boundaries of application: What are the conditions, and hence the industries, under which resource partitioning predictions should hold? Unfortunately, at present researchers have only rough heuristic guides such as the presence of economies of scale and industry maturity for answering this question (see Swaminathan, 1995).

We take the view that progress on this issue depends on both theoretical and empirical research. On the theoretical level, several very promising efforts to clarify, specify and extend the model have recently appeared (see Péli and Nooteboom, 1997; Peli, 1998; Boone and van Witteloostuijn, 1999; van Witteloostuijn et al., 1999). Our goal here is to examine further the empirical base of the theory. Toward that end, we examine resource partitioning theory in the context of the population of Dutch audit firms. In their survey of organizational ecology, Boone and van Witteloostuijn (1995) noted the consistency of the theory with certain historical facts of this organizational population. But their analysis was (as intended) only suggestive. Most importantly, 
Boone and van Witteloostuijn (1995) were not able in their wide-ranging article to explain thoroughly why or how the theory would operate among audit firms. This issue is important because resource partitioning theory is usually applied to populations of manufacturing organizations with large and diverse consumer markets (for example, newspapers, books, beer, wine and airline passenger service). Auditors' products and markets differ markedly: audit firms provide services rather than tangible products, they operate in buyer markets with businesses and other organizations rather than individuals, and they are subject to strong institutional controls by the profession and the government. As we discuss below, these differences challenge some of the basic arguments typically derived from the theory; they present an opportunity for theoretical development.

Boone and van Witteloostuijn (1995) also did not conduct any systematic empirical tests, leaving open the possibility that the theory may not actually hold in this context. Our data allow us to explore this issue in detail. Our analyses use life-history data on the 1,746 audit firms that (i) contained enough information and (ii) existed between 1896 and $1992 .{ }^{1}$ We specify and estimate formal tests of resource partitioning for the mortality process. While broadly consistent with the theory, the findings also show some complex and unexpected patterns that suggest additional theoretical considerations for resource partitioning. The strongest and most intriguing of these has to do with the interaction of resource partitioning markets and institutional controls.

This chapter is an extension of Chapter 4 in two ways. First, in testing resource partitioning theory, both the control variables and the human capital variables of Chapter 4 are included as covariates in this chapter. Therefore, the results reported in this chapter provide a more complete picture of audit firm longevity. ${ }^{2}$ Second, in this chapter a more elaborate method of event history analysis is used in the analyses.

The remainder of this chapter is as follows. Section 5.2 provides an overview of the contributions of resource partitioning in general. Section 5.3 elaborates on resource partitioning for professional service organizations, and derives some hypotheses. Then, Section 5.4 discusses the data and method. Section 5.5 reports the results. Finally, Section 5.6 concludes.

1 Note that the period considered in this chapter differs from that of Chapter 4 (i.e., 1930-1992). Because the primary interest of this chapter is in resource partitioning theory instead of human capital variables, we decided to include as large a period as possible.

2 This chapter, however, does not provide any results with respect to the different modes of exit (with respect to performance), because resource partitioning theory is explicitly concerned with overall firm longevity. 


\subsection{Resource partitioning: theory and evidence}

\subsubsection{Theory}

Resource partitioning theory (Carroll, 1985; Carroll and Hannan, 1995) addresses the interrelationship between two organizational trends often not thought to be related to each other. The first of these is the trend of increasing market concentration found in many industries, especially when the rise occurs gradually and over the long term, perhaps persisting for decades. The second is the increasingly common modern appearance of many small specialist organizations in certain mature industries. Resource partitioning theory explains why the two trends sometimes occur simultaneously within the same industry, a development previously considered highly implausible.

The core theoretical imagery of resource partitioning relies on notions of crowding among organizations in a market characterized as a finite set of heterogeneous resources. Organizations attempt to find viable positions within this market by targeting their products to various resource segments. Specialist organizations select narrow homogeneous targets, while generalist organizations choose targets composed of heterogeneous segments.

It is essential to the theory that some aspect of product delivery in the market possesses a scale advantage; this is typically envisioned as a strong economy of scale in production, marketing or distribution. Competition among generalist organizations in these markets consists of an ever-escalating war for resources. Because of the increasing returns to scale, the most intense fighting occurs in the densest or most abundant resource areas. The generalist organization that secures a toehold in this dense market 'center' possesses a potentially sustainable advantage over all competitors. Many generalists seek to establish themselves in this region. But because each originates from different locations and each seeks to maximize that part of its target without competitors, the set of competing generalists is somewhat differentiated. Larger generalists will eventually out-compete smaller ones, however. When the smaller generalists fail, their target markets become free resources. Generalists occupying adjacent regions hold the best positions for securing these newly available areas, and they typically do so. The surviving generalist thus becomes larger and more general. However, because of the wide range of a generalist's target area, it is difficult to secure the entire free space; doing so might prove more costly than it is worth or entail loss of some of the firm's existing target area. This is especially the case in mature markets where generalists are very large and possess extremely broad target areas. So as the competitive struggle among generalists proceeds to its eventual monopoly equilibrium, the size and target breadth of the survivors increase but the combined resource space held by all generalist organizations declines somewhat. 
The key mechanism for explaining the second trend addressed by resource partitioning theory, that of a burgeoning segment of specialist organizations, involves the resource space that lies outside the generalist target areas. It is here, away from the intense competitive pressure of the dominant large generalists, that specialist organizations can find viable locations. And because resources tend to be thin in these regions, the specialists located here tend to be small. Small highly specialized locations are also less likely to be invaded by the ever-encroaching generalists than are broader locations, and they tend to be more defensible if they are.

The basic insight of resource partitioning theory comes from comparing the amount of space available for specialists when overall market concentration rises. Because market concentration derives from generalist consolidation, this comparison can be made by measuring the total area outside generalist targets under different stages of the scale competition scenario. As explained above, this area comprises more space when concentration is higher (fewer and larger generalists). By this reasoning, resource partitioning theory thus yields its novel and central prediction: as overall market concentration rises, the viability of specialist organizations increases as well. Moreover, as Péli and Nooteboom (1997) demonstrate mathematically, the proportion of specialist space increases rapidly as the number of dimensions in resource space increases.

The main predictions of the theory, concerning the viability of specialist and generalist organizations under varying levels of concentration, have been interpreted with respect to both founding rates and mortality rates. It is useful to think of strong and weak forms of the hypotheses, both consistent with the theory. The strong form hypotheses state in absolute terms that as concentration rises, the founding rate of specialists increases and/or the mortality rate of specialists declines while the founding rate of generalists declines and/or the mortality rate increases. The weak form hypotheses make similar predictions in terms of relative rates: as concentration increases, the founding rate of specialists relative to generalist increases and the mortality rate of specialists relative to generalists declines. Thus, in the weaker form case, mortality rates of both forms could be rising with concentration but they should be rising at a slower rate for specialists than for generalists. In both cases, however, we expect an interaction between organizational form (specialist-generalist status) and concentration on a vital rate (i.e., either the founding or mortality rate). The question of which vital rate is not critical because the specialist segment can expand as a result of changes in either. 


\subsubsection{Evidence}

Empirical studies of resource partitioning have focused on the predictions about specialist organizations. Those studies reporting an effect on organizational vital rates consistent with the theory, span a wide variety of organizational populations. Carroll's (1985) study of the American newspaper industry examined the newspaper populations of seven metropolitan areas. He found that specialist paper mortality declined with concentration and generalist paper mortality increased. In a study of the early Iowa telephone industry, Barnett and Carroll (1987) found that the start-up rate of new companies increased when the average size of existing companies was large. Carroll and Swaminathan (1992) reported estimates for the contemporary American beer brewing (from 1975 to 1990), showing that the mortality rate of micro breweries declined with market concentration. They also revealed a nonmonotonic relationship between size and mortality for mass production breweries (generalists). A later follow-up analysis by Carroll and Swaminathan (1993) showed a significant positive effect of concentration in the beer market on microbrewery foundings. Freeman and Lomi (1994) and Lomi (1995) investigated patterns of founding among rural cooperative banks in Italy from 1964 to 1988 . They estimated models showing an increase in the founding rate of these specialist banks as size and market share of the national generalist banks rose. Swaminathan (1995) studied the American wine industry from 1941 to 1990 . He reported that the founding rate of farm wineries (specialists) rose as a function of overall market concentration. In his analysis of the evolution of the British car industry, Torres (1995) revealed an association between the vital rates of specialist automobile manufacturers and concentration. Wade (1996) examined the market for microprocessors from 1971 to 1989 and found that concentration fostered entry of new firms sponsoring architectural innovations. Seidel's (1997) investigation of the American airline industry after deregulation showed that concentration among the major airlines (who fly many places and use the hub-and-spoke route structure for scale economies) increased the founding rates and lowered the mortality rates of specialists carriers (who fly a few places from point-to-point). Dobrev (1997) studied the evolution of the Bulgarian newspaper industry, paying particular attention to the post-Socialist era. He found evidence of a reversal of the resource partitioning process, implying that the specialist segment declines with lowered concentration. Finally, Haveman and Nonnaker (1998) found that in the California savings and loan industry, entry by smaller organizations into new markets increased with market concentration. 


\subsection{Resource partitioning among professional service organizations}

\subsubsection{Theory and hypothesis}

Applications of resource partitioning theory are found almost exclusively in populations of organizations serving consumer markets. This is true for interpretative applications such as Powell's (1985) discussion of the book publishing industry as well as the systematic tests reviewed above (the only exception is the microprocessor study). It could be that the theory's domain consists of these types of industries, whose mass markets contain many diverse tastes. However, it could also be that researchers have simply not looked wide enough for evidence of resource partitioning.

An intriguing possibility for application of the theory that we explore here is a population of professional service organizations, the Dutch audit firms. Figures 2.1 and 2.2 of Chapter 2 present information on the two trends signifying possible operation of the partitioning process in this population. A long-term rise in concentration and a corresponding proliferation of small specialists can be seen clearly. The rise in concentration was accompanied by a steady increase in the average and maximum size of audit firms (Maijoor et al., 1995). The result is a dual market structure in which a few large firms coexist with a large number of small audit firms. Interestingly, the same audit market structure can be observed in other countries as well (see Danos and Eichenseher, 1986, for the U.S.A., Francis and Stokes, 1986, for Australia, Zind and Zéghal, 1989, for Canada, and Moizer and Turley, 1989, for the U.K.), suggesting that similar underlying market conditions drive this partitioning process.

Why would a population of professional service organizations become partitioned? Services are not tangible products that can be readily located in a product spectrum. Further, they are not sold to individuals but to other organizations and business firms. The rationale for buying professional services also varies substantially from that of consumer purchases. If resource partitioning operates in this population, then it seems clear that the mechanisms differ from those usually discussed for consumer markets. We address the issue here by discussing, first, why large firm size matters in auditing and, second, why very small (specialist) audit firms might be more attractive to some buyers when the population concentrates.

The audit literature has advanced several explanations for the steady increase in firm size and market concentration (Benston, 1985; Maijoor et al., 1995; Yardley et al., 1992). These explanations can be organized around two general classes of competitive advantages large firms possess over their smaller counterparts: cost advantages and (perceived) quality advantages. These advantages provided strong incentives for audit firms throughout the century to compete for the center of the market and to become big. 
The cost-related advantages of size reside in the growing importance of economies of scale and scope, which forced audit firms to adjust their size in order to survive (Maijoor et al., 1995). Audit firms continuously sink investments in developing and maintaining expertise in order to be able to provide services to clients. Because the knowledge and technology to compile, review and audit information is similar for many companies, it is economical to have a large client base, ceteris paribus (Benston, 1985). Over the twentieth century, the sunk investments needed to deliver quality services, increased substantially for two reasons. First, the growing regulatory complexity faced by clients had to be met with larger investments in expertise (Eichenseher and Danos, 1981; Maijoor et al., 1995). Eichenseher and Danos (1981), for instance, found that audit firm concentration within an industry (i.e., the percentage of total activity in an industry which is accounted for by the most active audit firms) was positively related to the extent of regulatory control impinging on the activity of firms in that industry. In the Netherlands, hardly any audit regulation existed before 1967 (Maijoor and van Witteloostuijn, 1996). Between 1967 and 1990, several important regulatory measures were implemented, increasing complexity considerably. The new laws (see Chapter 2, Section 2.2.4, and Section 5.3.2 of this chapter) intended to regulate the demand as well as the supply side of the Dutch audit market. Second, new technologies and related audit innovations were established and gradually implemented by audit firms. These included such things as risk analysis, statistical sampling and structured audit approaches, all increasing the minimum sunk costs necessary to deliver audit services (Maijoor et al., 1995; Maijoor, 1994).

Audit firms grew not only as the result of the existence of pure economies of scale in auditing but also because of the opportunity to reap economies of scope. The sunk costs made for developing and maintaining expertise to provide audit services can be more fully exploited by offering clients related advisory services (such as tax preparation, internal control systems design, consulting and personnel placement), and vice versa (Benston, 1985). For instance, industry knowledge, which must be gained to perform risk analyses for audit purposes, can also be used to conduct company strategy studies (Maijoor, 1994). It is therefore not surprising that large audit firms diversified into large firms offering an integrated range of specialized expertise and services (Yardley et al., 1992).

A final important cost-related advantage stems from what could be called size isomorphism, a concept implying that large clients can only be serviced efficiently by large audit firms (Benston, 1985). The primary reason for size isomorphism is that large auditees, consisting of many divisions which are frequently geographically dispersed, require the service of hundreds of auditors. For example, Benston (1985: 47) mentions that 400 auditors of 37 U.S. offices and 36 foreign offices of Peat, Marwick, Mitchell \& Co. were needed to audit the Singer Company in the 1970s. 
While a consortium of cooperating small audit firms could technically do the job, the cost of coordination would be outrageous (Benston, 1985).

Because of size isomorphism, the growing average size of firms in general and the increasing level of concentration at the demand side stimulated the demand for services of large relative to small audit firms. Specifically, in the Netherlands demandside concentration started to rise substantially from the 1960s onwards. As large clients favor large service firms, the same trend can also be observed in the audit industry (Maijoor et al., 1995). The result of these processes is a highly concentrated market especially among the large clients. Leeflang, Boxem and van Dijk (1992) report that the Dutch Big Four audit firms have a market share of $88 \%$ among the top-100 client firms in 1989. Similarly, Langendijk (1990) notes that the same Big Four performed almost $90 \%$ of the audits of all listed firms in the Netherlands in 1990 .

Concerning the (perceived) quality related advantages, Benston (1985) argues that the demand for auditing stems from the concern to confirm contract compliance by owners and professional managers. Specifically, "owners and managers use reputable public accountants who provide services that reduce the cost of monitoring employee activities and of assuring others that the owner and management activities are effectively monitored and reported" (Benston, 1985, p. 45). During this century, the demand for high-quality audits increased because of the growing separation of ownership and control, and the increased reliance on external financing. These developments stimulated demand for the services of large relative to small audit firms because the (perceived) quality of these services is deemed to be higher for several reasons. First, large audit firms voluntary invest in higher levels of expertise than smaller firms. Second, as mentioned above when discussing size isomorphism, larger clients especially can better be served with high quality by large audit firms (DeAngelo, 1981). This is because small audit firms would become too dependent on one specific client, making it difficult to resist client pressure. As high independence indicates high quality, large companies will tend to solicit the services of big audit firms (Maijoor and van Witteloostuijn, 1996). Third, large audit firms have more incentives to protect their reputation for expertise and integrity because of their investments in brand name reputation (Benston, 1985). This (perceived) quality difference has been invoked to explain the fee premium for large audit firms in the small-client market segment (Palmrose, 1986; Yardley et al., 1992).

Obviously, large size matters in the audit industry for a variety of reasons. But why might (as resource partitioning theory implies) small specialist audit firms be more attractive to some buyers when the industry concentrates? Small specialist auditors appear to possess three distinct advantages vis à vis their large counterparts which make their services attractive for small client firms under these conditions. 
First, the fees of large audit firms are higher (Palmrose, 1986). Small client firms are less willing to pay this premium because (1) the relative cost (to total firm revenues) of these expenditures is higher, (2) large auditors are likely to deploy their less experienced junior auditors to service small clients, and (3) the need of many small and medium-sized firms for high (perceived) audit quality is lower. Small companies depend less on external stakeholders, such as dispersed shareholders and external financiers, so the reputation of the auditor is often less important.

Second, the services of small audit firms are much more personalized than those of large auditors. In fact, the small firm auditor frequently becomes the confidant of the small business manager, providing personal advice and information on many issues including tax preparation, bookkeeping and regulations. Thus, the client can consult the same person on many problems at a relatively low cost. Such personalized services cannot be delivered by large audit firms in which labor is divided along separate functions, such as auditing and consulting. In addition, large audit firms have high labor turnover rates at low hierarchical positions because of the 'up-or-out' partner selection system (Maijoor and Meuwissen, 1993). ${ }^{3}$ This high turnover makes it difficult to establish personal relationships between (junior) auditors and small firm clients.

Third, Yardley et al. (1992) argued that the structured audit approach of large audit firms may give small auditors a competitive advantage in the small-client market. The reason is that such standardized approaches do not take into account the specific needs of small firms. In addition, standardization tends to reduce flexibility, leaving the advantage of providing customized services to small firms.

To summarize, large audit firms display a number of strong scale advantages that cause them to grow and diversify. But small audit firms still seem to possess special advantages in the small-client niche of the audit market where the large generalists also operate. Thus, the conditions for resource partitioning (i.e., incentives to grow and potential benefits of specialization occurring simultaneously) appear to be in place in the audit industry.

Note that in our analyses we equate specialism versus generalism with organizational size although there is not necessarily a one-to-one relationship between both concepts. This is because organizations can 'generalize' along several dimensions, such as types of products or services offered and types of clients served. Large audit firms can clearly be labeled generalists as far as their service portfolio and the size distribution of clients is concerned. That is, large audit firms target their products to various resource segments by (i) offering a range of diversified services, including auditing, and by (ii) competing on both the large and the small-client market segment. Small audit firms, however,

3. This implies that junior auditors are frequently evaluated concerning their potential for being a partner. If not, they have to leave the firm. 
predominantly focus their services to small clients which constitute a relatively homogeneous, narrow segment.

Recently, however, large audit firms started to specialize into servicing certain industries by investing in industry-specific expertise (Craswell et al., 1995). This is because different industries require different audit technologies, which drives the demand for industry specialization. In addition, by specializing large audit firms can avoid head-on competition in the market center. Indeed Craswell et al. (1995) show, for the Australian audit market, that industry specialist Big Eight auditors earn a 34 percent premium over non-specialized Big Eight auditors, indicating that industry specialization is an important basis for product differentiation within the large audit firm segment. Conversely, as far as types of clients are concerned, small audit firms might be quite generalist, auditing every type of business in the vicinity that needs audit services.

This tendency of large audit firms to specialize into servicing specific industries is not contradictory to the resource partitioning theory. It is in fact central to the theory that firms at any moment in time face a fundamental dilemma: a firm either opts for a growth strategy of fighting for the center of the market or prefers to avoid head-on competition by moving into the market's periphery. In our view, what is happening in the audit industry is that some large generalists started to avoid head-on scale-driven competition by differentiating away from the market center by means of industry-specific product differentiation. This within-segment, second-order resource partitioning process has also been observed in the Dutch newspaper industry (Boone and van Witteloostuijn, 1999). Thus, the first-order generalist-specialist size-based distinction has subsequently triggered a second-order product differentiation process among large audit firms. Note that this subtle tension between generalizing and specializing might eventually also initiate a search-for-scale among small audit firms by, for instance, merging with their local rivals. Irrespective of these subtleties, the bottom line is, however, that the (first-order) resource partitioning process has been triggered by the escalation of sunk investments into audit technology which necessitated firms to build a large client base and to compete for the center of the market. What makes small firms specialists in our view is their less standardized, low overhead approach that gives them the advantage of temporal flexibility and a customized approach. It is this focus on flexibility and customization that makes small firms niche players compared to large firms. We hypothesize that it is the tension between standardization and flexibility that underlies the partitioning process in the audit industry. Given the coincidence of specialism versus generalism and firm size in the audit industry, we expect that the effect of market concentration on the mortality rate will depend on the size of 
the firm. Specifically, the following hypothesis is tested:

H1: The effect of market concentration on the mortality rate will be smaller for small as opposed to large firms.

The hypothesis implies that in a model of mortality, the coefficient of the multiplicative interaction term of concentration and firm size will be positive. The specific values of the estimates will allow us to discern strong from weak forms of resource partitioning.

\subsubsection{Objections to the theory and hypothesis}

Despite the plausibility of the above reasoning, there are two strong theoretical reasons to believe that resource partitioning might not apply in this industry. Both concern institutional factors that might inhibit the free operation of market dynamics associated with the theory. The first has to do with the professional base of the service and the industry. Audit firms are not just service organizations, they are professional service organizations. As in most industrial countries, the Dutch audit profession is strong and, in many respects, self governing. The profession sets standards for membership and conduct; these standards are recognized by law. A person cannot do business as an official auditor without such certification. Because professions often fulfill selfinterests as well as the public interest, there may be rules and norms that unduly restrict entry and impede new firm formation (Wilensky, 1964; Abbott, 1988). A concentrated market may also create the conditions for consensus or even collusion by incumbent interests who potentially have the most to lose from new competitors.

The second reason to suspect that resource partitioning might not be unfettered concerns governmental regulations. Audits are legally proscribed activities for certain types of businesses. When the auditing requirements of the business world change as a result of regulatory change, then the demand for audit services changes as well. Such demand shifts may very well lead to restructuring of the organizational population, either in ways controlled by the profession (who may have prompted the legal change initially) or in unanticipated ways (Barnett and Carroll, 1987). Both might interrupt or reverse resource partitioning.

\subsubsection{Influence of the laws within the profession}

During the period of this study, two important major regulatory demand-side measures about auditing were enacted in the Netherlands (de Hen et al., 1995; Maijoor and van Witteloostuijn, 1996). These proscribe the types of companies that are submitted to audits. First, the Act on Annual Accounts of Companies of 1970 obliged all public 
companies, large private companies and cooperative societies to disclose audited annual accounts. Before 1970, there were only prescriptions for the so-called 'open' public companies, constituting 1.5 percent of the total number of public companies. Second, the scope of the 1970 law was considerably enlarged in 1983 under Title 8 of book 2 of the Civil Code. As of then every public and private company and cooperative society is obliged to disclose annual accounts. Small and medium-sized companies, however, are allowed to submit abridged annual accounts. Moreover, all large and medium-sized firms are required to have their annual accounts audited (Maijoor and van Witteloostuijn, 1996) (see Chapter 2, Section 2.2.4).

Three remarks are worth mentioning concerning the impetus behind these regulatory changes. First, the Dutch audit industry has a long history of institutionalized interest promotion, including lobbying activities (de Vries, 1985). Already at the beginning of this century, the explicit goal of the largest professional association at that time (i.e., NIVA, the predecessor of NIvRA) was precisely to regulate the profession and to strive for legally prescribed audit requirements (see de Vries, 1985, p. 88). In fact, the regulatory measures were prepared by government-installed commissions with important representatives from the audit profession. NIvRA as well as its predecessors succeeded in participating in the actual drafting of financial accounting and audit regulation (Maijoor and van Witteloostuijn, 1996). Thus, it is fair to say that effective lobbying has been an important determinant of government intervention (Boone and van Witteloostuijn, 1995).

Second, there are several indications that the large audit firms had an especially important influence on, and benefitted most from, the establishment of the regulations. Maijoor and van Witteloostuijn (1996, p. 554), for instance, remark that "Kraayenhof, one of the founders of the leading Dutch audit firm KPMG, played a very important role in the committee preparing the 1970 regulation." Every large audit firm in the Netherlands, without exception, has been founded by members of NIVA which played a major role in the lobbying for regulation from the beginning of the century throughout the 1960s (de Hen, 1995). In addition, Maijoor and van Witteloostuijn (1996) showed that the large audit firms and their RA partners as a group were able to appropriate most of the benefits resulting form the regulations.

Third, the extent to which small audit firms were involved in this lobbying process was presumably minimal. This can be deduced from the observation that the large firms benefitted most from the regulations. It is nevertheless interesting to observe that the profession itself recognized the specific needs of small and medium-sized client firms. For instance, in 1963 the commission Brands, which was one of the many commissions involved in the preparation of the regulations, reported that apart from the audit function which would be taken care of by the RA in the future, there was 
also a need for specialized administrative service providers for small and medium-sized companies (de Hen, 1995).

How did these laws impact the population of auditors? How did their effects mix with resource partitioning? Institutional theory (Meyer and Rowan, 1977) suggests strongly that the life chances of audit firms may have changed. To the extent that the laws were crafted or shaped with the guidance of the audit profession, we would assume that audit firms were not deleteriously affected and their life chances may have improved. However, this judgment depends strongly on the guidance and influence received being broadly representative of the profession. Suppose instead that the regulatory body was captured or more greatly influenced by the interests of large audit firms, as suggested above. In this case, the regulations might be less favorable to the smaller firms, which constitute the preponderance of all firms. Since we do not have full insight into the political processes behind these legal changes in Dutch audit requirements, we do not formulate explicit hypotheses about their impact on firm mortality. However, we suspect that they may have had strong effects which might mix with any observed resource partitioning processes. So when conducting basic tests of the theory from the hypothesis above, we include control variables for the demand-side regulatory periods. We focus on these specific measures because they directly influenced the carrying capacity of the audit industry. In a second stage of the analysis, we then look at changes in the processes by period, before and after these major demand-side changes. Our goal is to learn to what extent, if any, institutional change interacted with resource partitioning in driving the evolution of this population. In addition, these analyses will allow us to explore whether the dynamics of this organizational population affected the timing and form of the legislation and regulation (Hannan and Carroll, 1992).

\subsection{Data and method}

\subsubsection{Data sources and coding rules}

The database contains the life histories of 2,068 audit firms founded between 1880 and 1992 (see Chapter 2). In the current study, we focus only on the period 1896 to 1992 because the concentration rate in the early history of the industry is constructed on the basis of just a few firms, making it meaningless and artificially high. From 
approximately 1896 onwards, density becomes sufficiently high to compute meaningful concentration ratios. ${ }^{4}$

We aim at explaining the mortality rate of audit firms, which is defined as rate of exit from the market. Because the theory does not make any distinctions between exit types and the primary interest is in longevity in general, we do not differentiate between different modes of exit in our analyses. In this chapter, we find the differentiation between the pre- and post-law period of more importance.

\subsubsection{Variables and measurement}

The independent variables of primary interest are organizational size, market concentration and their interaction. We use two different measures of audit firm size: (1) a dummy indicating whether the firm is a single proprietorship or not; and (2) the natural logarithm of the number of auditors affiliated with a firm. The reason behind the use of these two size measures in this chapter, instead of just size as in Chapter 4 is as follows. The dummy for resource partitioning is taken because, if resource partitioning is at work in the Dutch audit market, it definitely has to be present for the large group of smallest firms in the industry. Besides this, the effect of an extra increase in size is used as a variable, i.e., the logarithm of size is taken. Furthermore, Meuwissen (1992) found that the correlations between firm revenue and the number of auditors employed by the firm in the years 1986,1988 and 1990 were all larger than 0.97 , underscoring the generality of our second size measure. We assess the degree of concentration by (3) the four-firm concentration ratio (C4). This ratio measures the sum of the market shares, in terms of the number of affiliated auditors of the four largest audit firms (see also Carroll, 1985). We use the four-firm ratio rather than alternatives because of the historical significance of the Big Four audit firms in the Dutch audit industry, and because of its consistency with Chapter $4 .^{5}$ For the interaction variables, we computed two product terms: (4) the multiplication of $\mathrm{C} 4$ with the single proprietorship dummy, and (5) the multiplication of $\mathrm{C} 4$ with the log size variable.

We also include several control variables. These control variables include all the control variables and all the human capital variables of Chapter 4 . The analyses in this chapter, therefore, elaborate on these results, providing a more complete picture with respect to overall audit firm longevity (through ignoring the different exit modes). To control for age dependence in mortality, we used a piece-wise constant rate specification with 11 age-defined period dummy variables (6) (the first 10 for every

4 Note that we performed sensitivity analyses which show that the results are robust for different starting dates of the period of study.

5 We also performed the analyses with $\mathrm{C} 8$ instead of $\mathrm{C} 4$. This does not affect the results substantially. 
two-year age interval from founding and the last one open) (see Chapter 3, Section 3.4.5). The division in different age groups is based on different estimated models. In a first model, different coefficients are estimated for all ages. Then, based on the significance levels of these estimates for the different ages, new more general models are estimated. Based on the log likelihoods of these different models, and their number of periods involved, a final model is selected. The dynamics in the market are covered by including the linear and squared terms for contemporaneous density ( 7 and 8 ), the number of entrant audit firms ( 9 ) and the number of new auditors (10). Furthermore, we constructed three period dummy variables. The effect of World War II is captured by a dummy variable (11) (1 for all firms that existed at the beginning of World War II, and 0 otherwise). The effects of the two demand-side regulations are traced with dummy variables: the first for the 1970 law (12) (coded as 1 for the spells between 1970 and 1983, and 0 otherwise), and the second for the 1983 law (13) (coded as 1 for the spells after 1983, and 0 otherwise). The four human capital variables which have been shown to influence the mortality rate (see the results of Chapter 4) of audit firms were also taken on board. These are: (14) the percentage of the founders of a firm with a university degree, (15) the change in the percentage of auditors of a firm with a university degree compared with the percentage at founding, (16) the average number of years of experience of the founders of a firm, and (17) the average number of years of experience of a firm at a particular point in time. All population-level variables $(\mathrm{C} 4$, density, density squared, number of new auditors and the number of entrant firms in the market) are measured at the beginning of each observation period (in other words, measurement of these variables is lagged one period). In Table 5.1 we report the descriptive statistics. 
CHAPTER 5: RESOURCE PARTITIONING PROCESSES AND AUDIT FIRM SURVIVAL

Table 5,1: Descriptive statistics of the data

\begin{tabular}{|c|c|c|c|c|c|}
\hline \# & Variable & Minimum & Maximum & Mean & $\begin{array}{l}\text { Standard } \\
\text { deviation }\end{array}$ \\
\hline & Longevity (in years) & 1 & 81 & 23.61 & 15.39 \\
\hline \multicolumn{6}{|c|}{ Panel A: basic model variables ${ }^{6}$} \\
\hline 7 & Density/100 & 0.07 & 4.37 & 2.99 & 0.81 \\
\hline 8 & Density $2 / 100$ & 0.49 & 1909.69 & 961.11 & 409.49 \\
\hline 9 & Number of entrant firms & 2 & 255 & 64.82 & 54.49 \\
\hline 10 & Number of new auditors & 1 & 542 & 191.81 & 139.39 \\
\hline 11 & Existence at begin WWII & 0 & 1 & 0.35 & 0.48 \\
\hline 12 & $\begin{array}{l}\text { Dummy law } 1970 \\
\text { (until 1983) }\end{array}$ & 0 & 1 & 0.21 & 0.41 \\
\hline 13 & Dummy law 1983 & 0 & 1 & 0.16 & 0.36 \\
\hline \multicolumn{6}{|c|}{ Panel B: human capital variables } \\
\hline 14 & Education at founding/100 & 0 & 1 & 0.21 & 0.39 \\
\hline 15 & Change in education $/ 100$ & -1 & 1 & 0.01 & 0.17 \\
\hline 16 & Experience at founding & 0 & 41 & 3.05 & 5.66 \\
\hline 17 & Experience & 0 & 66 & 10.63 & 8.77 \\
\hline \multicolumn{6}{|c|}{ Panel C: resource partitioning variables } \\
\hline 1 & Single proprietorship & 0 & 1 & 0.70 & 0.46 \\
\hline 2 & Log size (in auditors) & 0 & 6.25 & 0.42 & 0.84 \\
\hline 3 & $\mathrm{C} 4$ & 19.07 & 81.25 & 24.82 & 13.31 \\
\hline 4 & $\mathrm{C} 4 *$ single prop & 0 & 81.25 & 16.78 & 15.50 \\
\hline 5 & $\mathrm{C} 4 * \log$ size & 0 & 275.90 & 12.07 & 29.43 \\
\hline
\end{tabular}

6 Here, the descriptive statistics regarding the age of the firm are not given, because the age is not as such included in the analyses, i.e., the age dependency for different periods is included. 
CHAPTER 5: RESOURCE PARTITIONING PROCESSES AND AUDIT FIRM SURVIVAL

Table 5.1: Descriptive statistics of the data

\begin{tabular}{|c|c|c|c|c|c|}
\hline$\#$ & Variable & Minimum & Maximum & Mean & $\begin{array}{l}\text { Standard } \\
\text { deviation }\end{array}$ \\
\hline & Longevity (in years) & 1 & 81 & 23.61 & 15.39 \\
\hline \multicolumn{6}{|c|}{ Panel A: basic model variables ${ }^{6}$} \\
\hline 7 & Density/100 & 0.07 & 4.37 & 2.99 & 0.81 \\
\hline 8 & Density $2 / 100$ & 0.49 & 1909.69 & 961.11 & 409.49 \\
\hline 9 & Number of entrant firms & 2 & 255 & 64.82 & 54.49 \\
\hline 10 & Number of new auditors & 1 & 542 & 191.81 & 139.39 \\
\hline 11 & Existence at begin WWII & 0 & 1 & 0.35 & 0.48 \\
\hline 12 & $\begin{array}{l}\text { Dummy law } 1970 \\
\text { (until 1983) }\end{array}$ & 0 & 1 & 0.21 & 0.41 \\
\hline 13 & Dummy law 1983 & 0 & 1 & 0.16 & 0.36 \\
\hline \multicolumn{6}{|c|}{ Panel B: human capital variables } \\
\hline 14 & Education at founding/100 & 0 & 1 & 0.21 & 0.39 \\
\hline 15 & Change in education $/ 100$ & -1 & 1 & 0.01 & 0.17 \\
\hline 16 & Experience at founding & 0 & 41 & 3.05 & 5.66 \\
\hline 17 & Experience & 0 & 66 & 10.63 & 8.77 \\
\hline \multicolumn{6}{|c|}{ Panel C: resource partitioning variables } \\
\hline 1 & Single proprietorship & 0 & 1 & 0.70 & 0.46 \\
\hline 2 & Log size (in auditors) & 0 & 6.25 & 0.42 & 0.84 \\
\hline 3 & $\mathrm{C} 4$ & 19.07 & 81.25 & 24.82 & 13.31 \\
\hline 4 & $\mathrm{C} 4{ }^{*}$ single prop & 0 & 81.25 & 16.78 & 15.50 \\
\hline 5 & $\mathrm{C} 4 * \log$ size & 0 & 275.90 & 12.07 & 29.43 \\
\hline
\end{tabular}

- Here, the descriptive statistics regarding the age of the firm are not given, because the age is not as such included in the analyses, i.e., the age dependency for different periods is included. 
Table 5.2: Resource partitioning models (standard errors in parentheses) for total exit between 1896 and 1992

\begin{tabular}{|c|c|c|c|c|c|c|}
\hline \# & \multicolumn{2}{|c|}{ Variable } & \multicolumn{2}{|c|}{ Model a } & \multicolumn{2}{|c|}{ Model b } \\
\hline \multicolumn{7}{|c|}{ Panel A: basic model variables } \\
\hline \multirow[t]{7}{*}{6} & \multicolumn{6}{|c|}{ Age: 11 periods } \\
\hline & $0-2$ & $12-14$ & $-4.0326 * * *$ & $-4.6146^{* * * *}$ & $-4.5221^{* * *}$ & $-5.0943 * * *$ \\
\hline & $2-4$ & $14-16$ & $-4.2041^{* * *}$ & $-4.5918^{* * *}$ & $-4.6991^{* * *}$ & $-5.0622^{* * *}$ \\
\hline & $4-6$ & $16-18$ & $-4.3707^{* * *}$ & $-4.4184^{* * *}$ & $-4.8648^{* * *}$ & $-4.8920^{* * *}$ \\
\hline & $6-8$ & $18-20$ & $-4.4746 * * *$ & $-4.3132 * * *$ & $-4.9672^{* * * *}$ & $-4.7888 * * *$ \\
\hline & $8-10$ & 20 - Infinity & $-4.7652 * * *$ & $-4.1778 * * *$ & $-5.2493^{* * *}$ & $-4.6359 * * *$ \\
\hline & $10-12$ & & $-4.6217^{* * *}$ & & $-5.1067^{* * * *}$ & \\
\hline 7 & \multicolumn{2}{|c|}{ Density/100 } & 1.1657 & $(0.2226)^{* * *}$ & 1.1767 & $(0.2246)^{* * *}$ \\
\hline 8 & \multicolumn{2}{|c|}{ Density $^{2} / 100$} & -0.0021 & $(0.0004)^{* * *}$ & -0.0020 & $(0.0004)^{* * *}$ \\
\hline 9 & \multicolumn{2}{|c|}{ Number of entrant firms } & 0.0019 & $(0.0012)$ & 0.0016 & $(0.0012)$ \\
\hline 10 & \multicolumn{2}{|c|}{ Number of new auditors } & -0.0004 & $(0.0006)$ & -0.0003 & $(0.0006)$ \\
\hline 11 & \multicolumn{2}{|c|}{ Existence at begin WWII } & -0.7776 & $(0.0840)^{* * *}$ & -0.7726 & $(0.0837)^{* * * *}$ \\
\hline 12 & \multicolumn{2}{|c|}{$\begin{array}{l}\text { Dummy law } 1970 \\
\text { (until 1983) }\end{array}$} & -0.2717 & $(0.1867)$ & -0.3031 & $(0.1887)$ \\
\hline 13 & \multicolumn{2}{|c|}{ Dummy law 1983} & -0.1349 & $(0.2079)$ & -0.1726 & $(0.2093)$ \\
\hline \multicolumn{7}{|c|}{ Panel B: human capital variables } \\
\hline 14 & \multicolumn{2}{|c|}{ Education/100 } & -0.2459 & $(0.0777)^{* * *}$ & -0.2468 & $(0.0781)^{* * *}$ \\
\hline 15 & \multicolumn{2}{|c|}{ Change in education/100 } & -0.1319 & $(0.1809)$ & -0.1476 & $(0.1784)$ \\
\hline 16 & \multicolumn{2}{|c|}{ Experience at founding } & -0.0122 & $(0.0061)^{* *}$ & -0.0112 & $(0.0061)^{*}$ \\
\hline 17 & \multicolumn{2}{|c|}{ Experience } & 0.0334 & $(0.0047)^{* * *}$ & 0.0329 & $(0.0047)^{* * *}$ \\
\hline
\end{tabular}

Panel C: resource partitioning variables

1 Dummy single

proprietorship $\quad 0.1407(0.0978) \quad 0.7285 \quad(0.1617)^{* * *}$

2 Log size $\quad 0.0137 \quad(0.0542) \quad-0.0255 \quad(0.0544)$

$3 \mathrm{C} 4$

$0.0000 \quad(0.0082)$

$0.0169(0.0090)^{*}$

$4 \mathrm{C} 4 *$ single prop

$-0.0225(0.0047)^{* * *}$

$5 \mathrm{C} 4 * \log$ size

Panel D: statistics

Log likelihood only a

constant

$-4922.2821$

$-4922.2821$

Log likelihood model

$-4774.0666$

$-4762.6498$

\# of firms

1746

1746

\# of spells

10563

10563

\# of exits

1351

1351

Significance (two-tailed): ${ }^{*} \mathrm{p}<.10,{ }^{* *} \mathrm{p}<.05$ and ${ }^{* * *} \mathrm{p}<.01$. 
Table 5.2 (Continued): Resource partitioning models (standard errors in parentheses) for total exit between 1896 and 1992

\begin{tabular}{|c|c|c|c|c|c|c|}
\hline \# & \multicolumn{2}{|c|}{ Variable } & \multicolumn{2}{|c|}{ Model c } & \multicolumn{2}{|c|}{ Model d } \\
\hline \multicolumn{7}{|c|}{ Panel A: basic model variables } \\
\hline \multirow[t]{7}{*}{6} & \multicolumn{6}{|c|}{ Age: 11 periods } \\
\hline & $0-2$ & $12-14$ & $-3.9130 * * *$ & $-4.4875 * * *$ & $-4.8226^{* * *}$ & $-5.3965^{* * *}$ \\
\hline & $2-4$ & $14-16$ & $-4.0887^{* * *}$ & $-4.4588 * * *$ & $-4.9981^{* * *}$ & $-5.3657^{* * *}$ \\
\hline & $4-6$ & $16-18$ & $-4.2536 * * *$ & $-4.2848 * * *$ & $-5.1647^{* * *}$ & $-5.1973^{* * *}$ \\
\hline & $6-8$ & $18-20$ & $-4.3559 * * *$ & $-4.1799 * * *$ & $-5.2678^{* * *}$ & $-5.0948^{* * * *}$ \\
\hline & $8-10$ & 20 - Infinity & $-4.6420^{* * *}$ & $-4.0336 * * *$ & $-5.5505^{* * *}$ & $-4.9435^{* * *}$ \\
\hline & $10-12$ & & $-4.4971^{* * *}$ & & $-5.4090^{* * *}$ & \\
\hline 7 & \multicolumn{2}{|c|}{ Density/100 } & 1.1784 & $(0.2239)^{* * *}$ & 1.1705 & $(0.2244)^{* * *}$ \\
\hline 8 & \multicolumn{2}{|c|}{ Density $^{2} / 100$} & -0.0021 & $(0.0004)^{* * * *}$ & -0.0020 & $(0.0004)^{* * *}$ \\
\hline 9 & \multicolumn{2}{|c|}{ Number of entrant firms } & 0.0017 & $(0.0012)$ & 0.0017 & $(0.0012)$ \\
\hline 10 & \multicolumn{2}{|c|}{ Number of new auditors } & -0.0003 & $(0.0006)$ & -0.0003 & $(0.0006)$ \\
\hline 11 & \multicolumn{2}{|c|}{ Existence at begin WWII } & -0.7697 & $(0.0838)^{* * *}$ & -0.7767 & $(0.0838)^{* * *}$ \\
\hline 12 & \multicolumn{2}{|c|}{$\begin{array}{l}\text { Dummy law } 1970 \\
\text { (until 1983) }\end{array}$} & -0.2897 & $(0.1881)$ & -0.2988 & $(0.1884)$ \\
\hline 13 & \multicolumn{2}{|c|}{ Dummy law 1983} & -0.1554 & $(0.2088)$ & -0.1686 & $(0.2091)$ \\
\hline \multicolumn{7}{|c|}{ Panel B: human capital variables } \\
\hline 14 & \multicolumn{2}{|c|}{ Education/100 } & -0.2465 & $(0.0779)^{* * *}$ & -0.2467 & $(0.0781)^{* * *}$ \\
\hline 15 & \multicolumn{2}{|c|}{ Change in education/100 } & -0.1299 & $(0.1794)$ & -0.1553 & $(0.1788)$ \\
\hline 16 & \multicolumn{2}{|c|}{ Experience at founding } & -0.0113 & $(0.0061)^{*}$ & -0.0115 & $(0.0061)^{*}$ \\
\hline 17 & \multicolumn{2}{|c|}{ Experience } & 0.0326 & $(0.0047)^{* * *}$ & 0.0333 & $(0.0047)^{* * *}$ \\
\hline \multicolumn{7}{|c|}{ Panel C: resource partitioning variables } \\
\hline 1 & \multicolumn{2}{|c|}{$\begin{array}{l}\text { Dummy single } \\
\text { proprietorship }\end{array}$} & 0.0519 & $(0.1022)$ & 1.0397 & $(0.2631)^{* * *}$ \\
\hline 2 & \multicolumn{2}{|c|}{ Log size } & -0.2871 & $(0.1260)^{* *}$ & 0.2179 & $(0.1661)$ \\
\hline 3 & \multicolumn{2}{|l|}{$\mathrm{C} 4$} & -0.0026 & $(0.0083)$ & 0.0260 & $(0.0108)^{* *}$ \\
\hline 4 & \multicolumn{2}{|c|}{$\mathrm{C} 4 *$ single prop } & & & -0.0315 & $(0.0076)^{* * *}$ \\
\hline 5 & \multicolumn{2}{|c|}{$\mathrm{C} 4 * \log$ size } & 0.0078 & $(0.0028)^{* * *}$ & 0.0068 & $(0.0045)$ \\
\hline
\end{tabular}

Panel D: statistics

Log likelihood only a

constant

$-4922.2821$

$-4922.2821$

Log likelihood model

$-4770.2044$

$-4761.5002$

\# of firms

1746

1746

\# of spells

10563

10563

\# of exits

1351

1351

Significance (two-tailed): ${ }^{*} \mathrm{p}<.10,{ }^{* *} \mathrm{p}<.05$ and ${ }^{* * *} \mathrm{p}<.01$. 
to mail membership lists to existing firms (Maijoor et al., 1995). These systematic promotion efforts at the industry level might have replaced, at least in part, the densitybased legitimation process. This leaves us with the task of explaining the negative second-order effect of density. We already mentioned that the audit associations lobbied for decades to obtain legal recognition of their profession. It is only in the 1960 s that they succeeded when the audit profession was legitimized by law. These events occurred precisely when density was high and still increasing (see Figure 2.1 of Chapter 2). This might explain why the positive relationship of density with the mortality rate is decreasing at high density.

Turning to the resource partitioning variables, we see in models $b$ and $c$ that the parameters of $\mathrm{C} 4 *$ single proprietorship are significantly negative, and that of $\mathrm{C} 4$ * $\log$ size significantly positive. Thus hypothesis $\mathrm{H} 1$ is clearly supported. The estimates of model d, which contains both interaction variables, suggest that resource partitioning operates primarily on the survival chances of single proprietorships.?

Figure 5.1 displays graphically the interaction effect represented by the estimates of model b. Resource partitioning can be observed. When C4 is lower than .32, the standard size advantage (i.e., lower mortality rates for big firms) can be observed. However, the mortality rate decreases with rising concentration for single proprietorships (and small firms) but increases for large(r) firms.

7 Note that, partly based on these results, we expect that the resource partitioning process holds most for the case of longevity until pure exit. While it decreases the chance of exit by M\&A (especially with a large firm), because of the decreased survival rates for these larger firms. This expectation is informally supported by the statistics of Table 2.7 of Chapter 2, which show that most of the single proprietorships have a pure exit. 
Figure 5.1: Influence of $\mathrm{C} 4$ on the hazard rate for single and non-single proprietorships

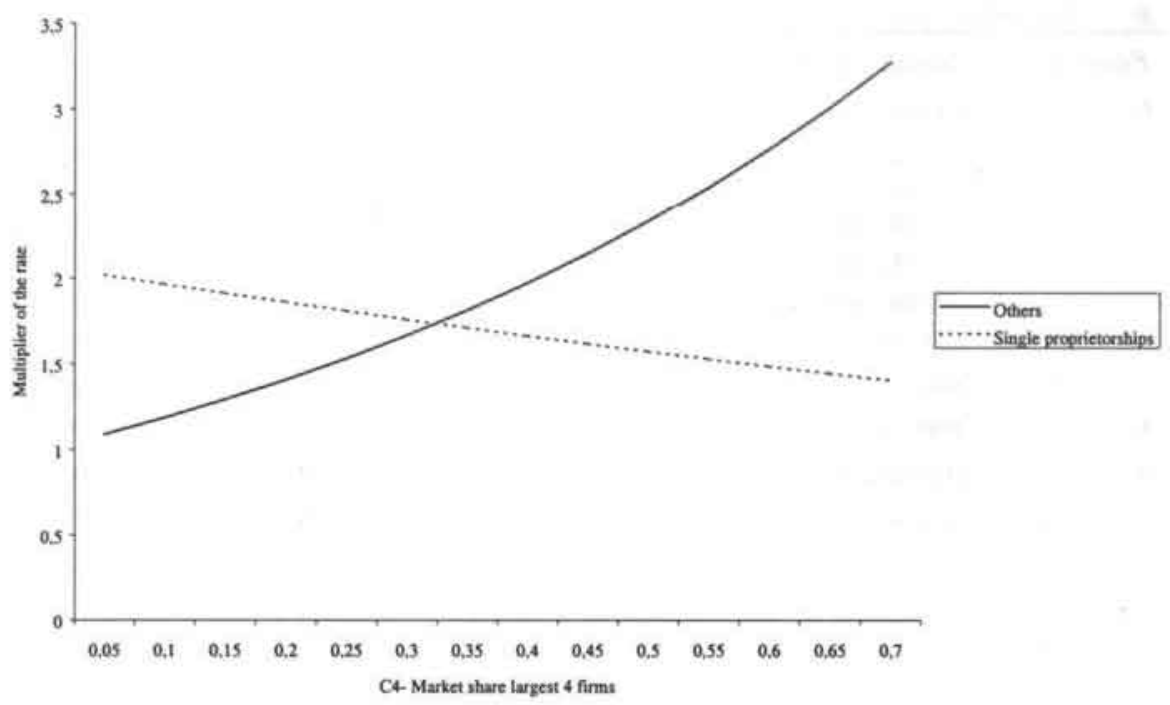

We reran the same four models for the periods before and after the major demand-side regulations. This amounts to dividing the data into two subsets, the first spanning 1896-1970 and the second from 1971-1992. The estimates are shown in Table 5.3.

Models $b$ and $c$ of Table 5.3 show strong and significant resource partitioning effects for the period before 1971 but not for the later period. Moreover, estimates of both interaction effects in the period before 1971 are much larger than those found for the full period (in Table 5.2). The pattern suggests that the dominant effect arises from the earlier period. 
Table 5.3: Resource partitioning models (standard errors in parentheses) for total exit between 1896 and 1970 and between 1971 and 1992

\begin{tabular}{|c|c|c|c|c|c|c|}
\hline$\#$ & Variat & & \multicolumn{2}{|c|}{ Model a before 1971} & \multicolumn{2}{|c|}{ Model a after 1971} \\
\hline \multicolumn{7}{|c|}{ Panel A: basic model variables } \\
\hline \multirow[t]{7}{*}{6} & Age: 1 & iods & & & & \\
\hline & $0-2$ & $12-14$ & $-3.3107^{* * *}$ & $-3.8382 * * *$ & $-11.0669^{* *}$ & $-11.6516^{* *}$ \\
\hline & $2-4$ & $14-16$ & $-3.6409 * * *$ & $-3.8631^{* * *}$ & $-10.9237^{* *}$ & $-11.4774 * *$ \\
\hline & $4-6$ & $16-18$ & $-3.6244 * * *$ & $-3.7135 * * *$ & $-11.3700 * *$ & $-11.2773^{* *}$ \\
\hline & $6-8$ & $18-20$ & $-3.9383^{* * *}$ & $-3.4740^{* * *}$ & $-11.0920^{* *}$ & $-11.5186^{* *}$ \\
\hline & $8-10$ & 20 - Infinity & $-4.2774 * * *$ & $-3.3270^{* * *}$ & $-11.3474 * *$ & $-11.2329^{* *}$ \\
\hline & $10-12$ & & $-3.9032 * * *$ & & $-11.4423^{* *}$ & \\
\hline 7 & Densit & & 0.6224 & $(0.2787)^{* *}$ & 4.6108 & $(2.3245)^{* *}$ \\
\hline 8 & Densit & & -0.0011 & $(0.0006)^{* *}$ & -0.0064 & $(0.0029)^{* *}$ \\
\hline 9 & Numb & entrant firms & -0.0037 & $(0.0018)^{* *}$ & 0.0116 & $(0.0094)$ \\
\hline 10 & Numb & new auditors & 0.0036 & $(0.0011)^{* * *}$ & -0.0041 & $(0.0019)^{* *}$ \\
\hline II & Existe & t begin WWII & -0.9307 & $(0.0990)^{* * *}$ & - & \\
\hline 12 & $\begin{array}{l}\text { Dumm } \\
\text { (until }\end{array}$ & 1970 & - & & - & \\
\hline 13 & Dumm & 1983 & - & & -0.1882 & $(0.2474)$ \\
\hline \multicolumn{7}{|c|}{ Panel B: human capital variables } \\
\hline 14 & Educa & $t$ founding $/ 100$ & -0.3284 & $(0.1068)^{* * * *}$ & -0.2057 & $(0.1149)^{*}$ \\
\hline 15 & Chang & ducation/100 & 0.0033 & $(0.2815)$ & -0.2706 & $(0.2357)$ \\
\hline 16 & Experi & at founding & -0.0269 & $(0.0086)^{* * *}$ & 0.0073 & $(0.0085)$ \\
\hline 17 & Experi & & 0.0311 & $(0.0063)^{* * *}$ & 0.0326 & $(0.0070)^{* * *}$ \\
\hline \multicolumn{7}{|c|}{ Panel C: resource partitioning variables } \\
\hline 1 & $\begin{array}{l}\text { Dumm } \\
\text { propri }\end{array}$ & & 0.4241 & $(0.1466)^{* * *}$ & -0.2008 & $(0.1412)$ \\
\hline 2 & Log si: & & 0.0782 & $(0.0911)$ & -0.0788 & $(0.0710)$ \\
\hline 3 & $\mathrm{C} 4$ & & -0.0162 & $(0.0097)^{*}$ & 0.0239 & $(0.0223)$ \\
\hline 4 & $\mathrm{C} 4 * \sin$ & rop & & & & \\
\hline 5 & $\mathrm{C} 4 * \mathrm{lo}$ & & & & & \\
\hline \multicolumn{7}{|c|}{ Panel D: statistics } \\
\hline & $\begin{array}{l}\text { Log lit } \\
\text { consta }\end{array}$ & d only a & & -3163.8858 & & -1758.2541 \\
\hline & Log lit & od model & & -3010.8005 & & -1707.7578 \\
\hline & \# of fir & & & 1116 & & 875 \\
\hline & $\#$ of $\mathrm{sp}$ & & & 6985 & & 3578 \\
\hline & $\#$ of ex & & & 871 & & 480 \\
\hline
\end{tabular}

Significance (two-tailed): ${ }^{*} \mathrm{p}<.10,{ }^{* *} \mathrm{p}<.05$ and ${ }^{* * *} \mathrm{p}<.01$. 
Table 5.3 (Continued): Resource partitioning models (standard errors in parentheses) for total exit between 1896 and 1970 and between 1971 and 1992

\begin{tabular}{|c|c|c|c|c|c|c|}
\hline$\#$ & Variab & & \multicolumn{2}{|c|}{ Model b before 1971} & \multicolumn{2}{|c|}{ Model b after 1971} \\
\hline \multicolumn{7}{|c|}{ Panel A: basic model variables } \\
\hline \multirow[t]{7}{*}{6} & \multicolumn{6}{|c|}{ Age: 11 periods } \\
\hline & $0-2$ & $12-14$ & $-4.2416^{* * *}$ & $-4.7650 * * *$ & $-11.2674^{* *}$ & $-11.8511^{* *}$ \\
\hline & $2-4$ & $14-16$ & $-4.5714 * * *$ & $-4.7908 * * *$ & $-11.1246^{* *}$ & $-11.6754 * *$ \\
\hline & $4-6$ & $16-18$ & $-4.5507 * * *$ & $-4.6615^{* * *}$ & $-11.5707 * *$ & $-11.4744^{* *}$ \\
\hline & $6-8$ & $18-20$ & $-4.8556 * * *$ & $-4.4290 * * *$ & $-11.2924 * *$ & $-11.7154^{* *}$ \\
\hline & $8-10$ & 20 - Infinity & $-5.1882^{* * *}$ & $-4.2681^{* * * *}$ & $-11.5468^{* *}$ & $-11.4308 * *$ \\
\hline & $10-12$ & & $-4.8232 * * *$ & & $-11.6419^{* *}$ & \\
\hline 7 & Densit & & 0.5643 & $(0.2803)^{* * *}$ & 4.6158 & $(2.3245)^{* *}$ \\
\hline 8 & Densit & & -0.0010 & $(0.0006)^{*}$ & -0.0064 & $(0.0029)^{* *}$ \\
\hline 9 & Numb & entrant firms & -0.0050 & $(0.0018)^{* * *}$ & 0.0116 & $(0.0094)$ \\
\hline 10 & Numb & new auditors & 0.0043 & $(0.0011)^{* * *}$ & -0.0041 & $(0.0019)^{* *}$ \\
\hline 11 & Existe & begin WWII & -0.9300 & $(0.0981)^{* * *}$ & - & \\
\hline 12 & $\begin{array}{l}\text { Dumm } \\
\text { (until }\end{array}$ & 1970 & - & & - & \\
\hline 13 & Durmm & 83 & - & & -0.1885 & $(0.2474)$ \\
\hline \multicolumn{7}{|c|}{ Panel B: human capital variables } \\
\hline 14 & Educat & $t$ founding $/ 100$ & -0.3332 & $(0.1074)^{* * *}$ & -0.2054 & $(0.1149)^{*}$ \\
\hline 15 & Chang & ducation/100 & 0.0217 & $(0.2807)$ & -0.2725 & $(0.2357)$ \\
\hline 16 & Experi & at founding & -0.0279 & $(0.0085)^{* * *}$ & 0.0073 & $(0.0085)$ \\
\hline 17 & Experi & & 0.0322 & $(0.0063)^{* * *}$ & 0.0326 & $(0.0070)^{* * * *}$ \\
\hline \multicolumn{7}{|c|}{ Panel C: resource partitioning variables } \\
\hline 1 & $\begin{array}{l}\text { Dumm } \\
\text { propric }\end{array}$ & & 1.8097 & $(0.3024)^{* * *}$ & 0.0984 & $(0.9834)$ \\
\hline 2 & $\log s i$ & & -0.0247 & $(0.0891)$ & -0.0801 & $(0.0712)$ \\
\hline 3 & $\mathrm{C} 4$ & & 0.0396 & $(0.0136)^{* * *}$ & 0.0284 & $(0.0267)$ \\
\hline 4 & $\mathrm{C} 4 * \sin$ & rop & -0.0807 & $(0.0148)^{* * *}$ & -0.0071 & $(0.0231)$ \\
\hline 5 & $\mathrm{C} 4 *$ lo & & & & & \\
\hline \multicolumn{7}{|c|}{ Panel D: statistics } \\
\hline & $\begin{array}{l}\text { Log lit } \\
\text { consta }\end{array}$ & od only a & & -3163.8858 & & -1758.2541 \\
\hline & Log lit & od model & & -2996.0456 & & -1707.7105 \\
\hline & \# of fir & & & 1116 & & 875 \\
\hline & $\#$ of sp & & & 6985 & & 3578 \\
\hline & \# of ex & & & 871 & & 480 \\
\hline
\end{tabular}

Significance (two-tailed): ${ }^{*} \mathrm{p}<.10,{ }^{* *} \mathrm{p}<.05$ and ${ }^{* * *} \mathrm{p}<.01$. 
Table 5.3 (Continued): Resource partitioning models (standard errors in parentheses) for total exit between 1896 and 1970 and between 1971 and 1992

\begin{tabular}{|c|c|c|c|c|c|c|}
\hline \multirow{2}{*}{\multicolumn{3}{|c|}{$\begin{array}{l}\# \quad \text { Variable } \\
\text { Panel A: basic model variables }\end{array}$}} & \multicolumn{2}{|c|}{ Model c before 1971} & \multicolumn{2}{|c|}{ Model c after 1971} \\
\hline & & & & & & \\
\hline \multirow[t]{7}{*}{6} & \multicolumn{6}{|c|}{ Age: 11 periods } \\
\hline & $0-2$ & $12-14$ & $-2.6316^{* * *}$ & $-3.1382^{* * *}$ & $-11.6458 * *$ & $-12.2371^{* *}$ \\
\hline & $2-4$ & $14-16$ & $-2.9613^{* * *}$ & $-3.1534 * * *$ & $-11.4958 * *$ & $-12.0711 * *$ \\
\hline & $4-6$ & $16-18$ & $-2.9380^{* * *}$ & $-3.0106 * * *$ & $-11.9396 * *$ & $-11.8798 * *$ \\
\hline & $6-8$ & $18-20$ & $-3.2371^{* * *}$ & $-2.7732 * * *$ & $-11.6714 * *$ & $-12.1207^{* *}$ \\
\hline & $8-10$ & 20 - Infinity & $-3.5630^{* * *}$ & $-2.5975^{* * *}$ & $-11.9339 * *$ & $-11.8212 * *$ \\
\hline & $10-12$ & & $-3.1938^{* * *}$ & & $-12.0283^{* *}$ & \\
\hline 7 & \multicolumn{2}{|c|}{ Density/100 } & 0.5688 & $(0.2805)^{* *}$ & 4.6192 & $(2.3260)^{* *}$ \\
\hline 8 & \multicolumn{2}{|c|}{ Density ${ }^{2} / 100$} & -0.0010 & $(0.0006)^{*}$ & -0.0064 & $(0.0029)^{* *}$ \\
\hline 9 & \multicolumn{2}{|c|}{ Number of entrant firms } & -0.0051 & $(0.0018)^{* * *}$ & 0.0117 & $(0.0094)$ \\
\hline 10 & \multicolumn{2}{|c|}{ Number of new auditors } & 0.0043 & $(0.0011)^{* * *}$ & -0.0041 & $(0.0019)^{* *}$ \\
\hline 11 & \multicolumn{2}{|c|}{ Existence at begin WWII } & -0.9229 & $(0.0981)^{* * *}$ & - & \\
\hline 12 & \multicolumn{2}{|c|}{$\begin{array}{l}\text { Dummy law } 1970 \\
\text { (until 1983) }\end{array}$} & \multicolumn{2}{|l|}{ - } & \multicolumn{2}{|l|}{ - } \\
\hline 13 & \multicolumn{2}{|c|}{ Dummy law 1983} & \multicolumn{2}{|l|}{-} & -0.1849 & $(0.2475)$ \\
\hline
\end{tabular}

\section{Panel B: human capital variables}

14 Education at founding/100

15 Change in education $/ 100$

\begin{tabular}{rlrl}
-0.3337 & $(0.1073)^{* * *}$ & -0.2076 & $(0.1149)^{*}$ \\
0.0248 & $(0.2779)$ & -0.2701 & $(0.2359)$ \\
-0.0259 & $(0.0085)^{* * *}$ & 0.0074 & $(0.0085)$ \\
0.0296 & $(0.0062)^{* * *}$ & 0.0328 & $(0.0070)^{* * *}$ \\
\hline
\end{tabular}

16 Experience at founding

17 Experience

\section{Panel C: resource partitioning variables}

1 Dummy single

\begin{tabular}{|c|c|c|c|c|c|}
\hline & proprietorship & 0.1265 & $(0.1550)$ & -0.2070 & $(0.1413)$ \\
\hline 2 & Log size & -1.1002 & $(0.2531)^{* * *}$ & 0.9160 & $(0.4877)^{*}$ \\
\hline 3 & $\mathrm{C} 4$ & -0.0372 & $(0.0109)^{* * *}$ & 0.0372 & $(0.0233)$ \\
\hline 4 & $\mathrm{C} 4 *$ single prop & & & & \\
\hline$\underline{5}$ & $\mathrm{C} 4 * \log$ size & 0.0496 & $(0.0019)^{* * *}$ & -0.0236 & $(0.0117)^{* *}$ \\
\hline \multicolumn{6}{|c|}{ Panel D: statistics } \\
\hline & $\begin{array}{l}\text { Log likelihood only a } \\
\text { constant }\end{array}$ & & -3163.8858 & & -1758.2541 \\
\hline & Log likelihood model & & -2995.1300 & & -1705.6449 \\
\hline & \# of firms & & 1116 & & 875 \\
\hline & \# of spells & & 6985 & & 3578 \\
\hline & $\#$ of exits & & 871 & & 480 \\
\hline
\end{tabular}

Significance (two-tailed): ${ }^{*} \mathrm{p}<.10,{ }^{* *} \mathrm{p}<.05$ and ${ }^{* * *} \mathrm{p}<.01$. 
Table 5.3 (Continued): Resource partitioning models (standard errors in parentheses) for total exit between 1896 and 1970 and between 1971 and 1992

\begin{tabular}{|c|c|c|c|c|c|c|}
\hline \# & \multicolumn{2}{|c|}{ Variable } & \multicolumn{2}{|c|}{ Model d before 1971} & \multicolumn{2}{|c|}{ Model d after 1971} \\
\hline \multicolumn{7}{|c|}{ Panel A: basic model variables } \\
\hline \multirow[t]{7}{*}{6} & \multicolumn{6}{|c|}{ Age: 11 periods } \\
\hline & $0-2$ & $12-14$ & $-3.3507^{* * *}$ & $-3.8638^{* * *}$ & $-15.2484 * * *$ & $-15.8280^{* * *}$ \\
\hline & $2-4$ & $14-16$ & $-3.6804 * * *$ & $-3.8832 * * *$ & $-15.0912 * * *$ & $-15.6573^{* * *}$ \\
\hline & $4-6$ & $16-18$ & $-3.6577^{* * *}$ & $-3.7485^{* * *}$ & $-15.5302 * * *$ & $-15.4674^{* * *}$ \\
\hline & $6-8$ & $18-20$ & $-3.9577^{* * *}$ & $-3.5140^{* * *}$ & $-15.2706 * * *$ & $-15.7050^{* * *}$ \\
\hline & $8-10$ & 20 - Infinity & $-4.2855 * * *$ & $-3.3429 * * *$ & $-15.5289^{* * *}$ & $-15.3949 * * *$ \\
\hline & $10-12$ & & $-3.9198 * * *$ & & $-15.6249^{* * * *}$ & \\
\hline 7 & \multicolumn{2}{|c|}{ Density/100 } & 0.5595 & $(0.2806)^{* *}$ & 4.7326 & $(2.3281)^{* * *}$ \\
\hline 8 & \multicolumn{2}{|c|}{ Density $2 / 100$} & -0.0010 & $(0.0006)^{*}$ & -0.0065 & $(0.0029)^{* *}$ \\
\hline 9 & \multicolumn{2}{|c|}{ Number of entrant firms } & -0.0053 & $(0.0018)^{* * *}$ & 0.0115 & $(0.0094)$ \\
\hline 10 & \multicolumn{2}{|c|}{ Number of new auditors } & 0.0044 & $(0.0011)^{* * *}$ & -0.0040 & $(0.0019)^{* *}$ \\
\hline 11 & \multicolumn{2}{|c|}{ Existence at begin WWII } & -0.9261 & $(0.0980)^{* * *}$ & \multicolumn{2}{|l|}{ - } \\
\hline 12 & \multicolumn{2}{|c|}{$\begin{array}{l}\text { Dummy law } 1970 \\
\text { (until 1983) }\end{array}$} & \multicolumn{2}{|l|}{ - } & \multicolumn{2}{|l|}{ - } \\
\hline 13 & \multicolumn{2}{|c|}{ Dummy law 1983} & \multicolumn{2}{|l|}{ - } & -0.1846 & $(0.2477)$ \\
\hline \multicolumn{7}{|c|}{ Panel B: human capital variables } \\
\hline 14 & \multicolumn{2}{|c|}{ Education at founding/100 } & -0.3340 & $(0.1075)^{* * * *}$ & -0.2076 & $(0.1149)^{*}$ \\
\hline 15 & \multicolumn{2}{|c|}{ Change in education/100 } & 0.0246 & $(0.2789)$ & -0.2950 & $(0.2356)$ \\
\hline 16 & \multicolumn{2}{|c|}{ Experience at founding } & -0.0268 & $(0.0085)^{* * *}$ & 0.0079 & $(0.0085)$ \\
\hline 17 & \multicolumn{2}{|c|}{ Experience } & 0.0308 & $(0.0063)^{* * *}$ & 0.0322 & $(0.0070)^{* * *}$ \\
\hline
\end{tabular}

\section{Panel C: resource partitioning variables}

1 Dummy single proprietorship

2 Log size

$3 \mathrm{C} 4$

$4 \mathrm{C} 4 *$ single prop

$5 \mathrm{C} 4 * \log$ size

$\begin{aligned} 0.9372 & (0.4947)^{*} \\ -0.6804 & (0.3422)^{* * *} \\ -0.0016 & (0.0231) \\ -0.0406 & (0.0234)^{*} \\ 0.0310 & (0.0141)^{* *}\end{aligned}$

$3.7590(1.4558)^{* * *}$

$2.3952(0.7356)^{* * *}$

$0.1178(0.0377)^{* * *}$

$-0.0943(0.0344)^{* * *}$

$-0.0593(0.0180)^{* * *}$

Panel D: statistics

Log likelihood only a

constant

$-3163.8858$

$-1758.2541$

Log likelihood model

$-2993.6217$

$-1701.8949$

\# of firms

1116

875

\# of spells

6985

3578

\# of exits

871

480

Significance (two-tailed): ${ }^{*} \mathrm{p}<.10,{ }^{* *} \mathrm{p}<.05$ and ${ }^{* * *} \mathrm{p}<.01$. 
The predicted effects associated with model b (the period before 1971) are shown in Figure $5.2{ }^{8}$ Resource partitioning can be observed. That is, the mortality rate decreases with rising concentration for single proprietorships (and small firms) but increases for large(r) firms. Interestingly, after the major regulations were instituted, the resource partitioning process apparently came to an end (see Model b, c, and d after 1971).

Figure 5.2: Influence of $\mathrm{C} 4$ on the hazard rate for single and non-single proprietorships before 1971

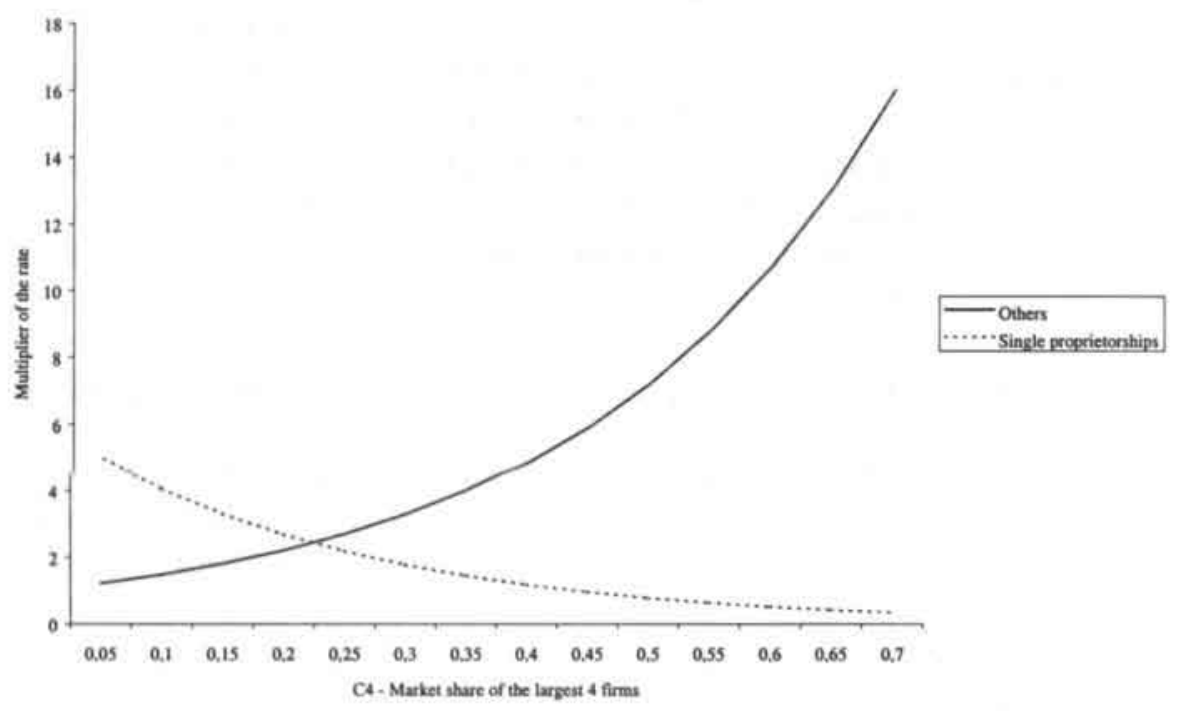

\subsection{Discussion and conclusion}

To summarize, our findings suggest that the mortality rate of specialist and generalist audit firms in the Netherlands were indeed shaped by resource partitioning processes. Although numerous tests of resource partitioning theory have appeared, this is the first (to our knowledge) that considers professional service organizations. The context is potentially significant for delineating the boundaries of the theory; the markets

8 For the sake of parsimony, we only present the graph for the predicted effects of the $\mathrm{C} 4$ times single proprietorship interaction. 
and institutional controls of Dutch auditing differ markedly from the consumer products industries where the theory has been usually applied. In particular, audit services are purchased by organizations rather than individuals. Auditing is also a self-regulated profession sanctioned by the state.

We believe that the service function of the audit industry is critical to understanding why resource partitioning occurs here. The niche position of specialist audit firms seems to be sustained by their flexibility over time. This dynamic capability allows specialist firms to meet the unique and changing needs of certain clients and other customers. In essence, they provide customized and personalized service of a kind that the large generalist audit firms are incapable of providing (at least to small client firms). Of course, they are also cheaper than the large audit firms.

The customization appeal of small specialized auditors differs markedly from the location-based crowding mechanism of the original resource partitioning theory. In our view, the crowding theory can only explain fully some of the industries where resource partitioning occurs. The best case is perhaps the airline passenger service industry, where location has a concrete geographical meaning (Seidel, 1997). Many other industries with resource partitioning are similar to beer brewing in that the sustained appeal of specialist organizations appears to emanate from their identity (Carroll and Swaminathan, 1998). Plausible other cases here include music recording, book publishing and newspapers. In a third set of industries, closely related mechanisms involving the conspicuous status consumption of specialty firms' products appear to be at work. The best example is the wine industry (Swaminathan, 1998). Finally, a fourth set of industries resemble auditing in that flexibility and customization seem to be theoretically central. The banking industry is another good example where this type of mechanism appears to be at work in generating a partitioned industry. Obviously, significant further theoretical and empirical exploration into the various sociological processes underlying resource partitioning is warranted. ${ }^{9}$

The Dutch auditing context also shows how strongly and unexpectedly institutional environments can affect resource partitioning processes. Recall that small auditors were especially prevalent in the late stages of the industry, suggesting that resource partitioning was operating at that time. Yet, statistical analyses by period showed that resource partitioning was especially at work in an earlier period - before the rules of the game were fixed by law.

The pattern suggests two conclusions with general implications. First, because the predicted effects are strongest in the unregulated era (see results Table 5.3), competition among the different organizational forms does indeed seem to be the

9 See also the many product differentiation theories and studies in economics. For an integration (IO - OE) effort, see Boone, Carroll and van Witteloostuijn (1999) and van Witteloostuijn, Carroll and Boone (1999). 
force driving resource partitioning processes. Second, there is a subtle interplay between ecological processes on the one hand and legislation and regulation on the other hand. It is as though the effects of resource partitioning are institutionalized in the legislation.

Finally, the present study suggests two important avenues for further research. First, much more work is required to investigate the interesting relationship between the dynamics of organizational populations on the one hand and the timing and form of legislation and regulation on the other hand. As mentioned above, our research points to a subtle interplay between both processes. We speculated that the ecological process causing a dual market structure was accelerated and institutionalized by law. Of course, we need much more insight into the political processes behind these legal changes to confirm this speculation. Second, the interesting tension between generalism and specialism, between competing for the center of the market and differentiation, deserves more attention. On the one hand, it poses a challenge for resource partitioning theory to identify and define the important dimensions along which firms 'generalize' in different industries (Boone et al., 1999). In the context of the audit industry, a careful analysis of the client portfolio of large versus small firms (over time) might be revealing indeed. On the other hand, it is important to unravel the dynamics of the resource partitioning process itself. That is, more insight is needed into how scale and scopedriven partitioning processes, causing a dual market structure, relate to second-order within segment competition (Boone and van Witteloostuijn, 1999). This might shed light on when and why generalists specialize and specialists generalize. 


\title{
PUSH AND PULl FaCtORS AS DETERMINANTS OF SPINOFFs IN THE AUDIT INDUSTRY
}

\author{
Chapter 6, as the final empirical chapter, addresses the third \\ research question: How do market and firm characteristics \\ influence the chances of a firm having a spinoff? In answering this \\ question, this chapter provides a first analysis of a subject hardly \\ studied before: the spinoffs in the audit industry.
}

\subsection{Introduction}

In the audit industry one frequently observes that auditors leave their audit firm to start a new one, either alone or in a group. This phenomenon is referred to as a spinoff. ${ }^{1}$ The reason for the high incidence of spinoffs in the audit industry is that the audit industry is a professional service industry in which starting your own firm is relatively easy. That is, once the license to audit is there, entry barriers are very low indeed as start up costs are close to zero. When such a spinoff takes place, it often involves a lot of enmity between the parent firm (the firm the auditors are leaving) and the newly founded spinoff. The main reason for this lies again in the professional service character of the industry, which inherently implies that the individual auditors of a firm have client-specific knowledge and contacts. This can easily result in problems, since a newly founded spinoff needs clients to survive. ${ }^{2}$ Hence, the auditor(s) establishing the spinoff will attempt to capture clients from his/their former audit

\footnotetext{
Another situation, which is also referred to as a spinoff, is when a firm sets up a new entity in order to develop a by-product of an innovation. This type of spinoff is not considered in this chapter.

2 Nowadays, frequently terms regarding the taking of clients are set out in the contracts of employees. Such contracts usually contain terms about the time period during which it is forbidden for an ex-employee to perform services for clients from the old firm. Furthermore, a fine is set against breaking these terms. Anecdotal evidence, however, suggests that this remains an issue of conflict between the parent firm and the spinoff. Furthermore, the Dutch government is trying to limit the use of such anti-competitive contracts, as well as their impact (de Bontridder, 1997).
} 
firm(s). The high incidence of spinoffs together with the potential problems for the parent firm as a result of the spinoff make audit spinoffs an interesting study object.

Despite the wide familiarity with, and interest in, this phenomenon in practice, to our knowledge, not much fundamental research has been conducted into this subject. Two exceptions are the calculation of entry rates as a result of spinoff for the Dutch audit market by Buijink et al. (1998) and Pennings et al. (1998), the latter including the spinoff event as an explanatory variable in their longevity study. Partly because of the issue of conflict, especially the factors that make people leave their current firm and start their own enterprise are of interest. This chapter, therefore, seeks to determine what factors influence the chance of a parent firm experiencing a spinoff. In doing so, this chapter's level of analysis is the individual spinoff.

Because of the absence of research regarding this subject, more general research on market and firm dynamics as well as career patterns will be used to develop the hypotheses (e.g., Wholey, 1985; Hannan, 1988; Hachen, 1992; Haveman and Cohen, 1994). Based on this research, we divide the variables that can influence the chance of a spinoff into two main categories, i.e., push factors and pull factors. Push factors represent the factors that, dependent on their influence, can push employees out of the firm. They represent the change in the (un)attractiveness for auditors to stay with their current firm, i.e., they attempt to explain staff turnover particularly within a firm (the number of employees who quit). Hence, these variables determine the (lack of) opportunities and the degree of conflict the auditors are facing within the parent firm. Pull factors represent the factors that, dependent on their influence, can pull employees into the market. In other words, they represent the (un)attractiveness for auditors of entering the market by means of founding a new firm. Hence, these variables determine the (lack of) opportunities for a new firm within the market. This distinction is analogous to the more general remark of Hachen (1992, p. 40) concerning motives to quit an employer: "Inter-firm moves (quits) are a function of (1) the opportunities an employee has with other employers relative to (2) the opportunities by the current employer", and Hannan's observation (1988, p. 171) that "Under such circumstances, the potential gains from starting or joining a new, novel organization rarely offset the high uncertainty of the new venture. Good career prospects translate into low rates of innovation in forms and low founding rates." ... "As the portion of unfilled and dissatisfied demand for services grows, the gains from creating new organizations specially tailored to meet demand grow."

In studying spinoffs in the Dutch audit industry, this chapter considers the Dutch audit market from its origin in 1880 until 1992. This results in a total of 2,929 cases (i.e., observations by firm by period) for firms with more than one auditor and 298 spinoffs. Further, the technique of event history analysis is applied to estimate spinoff hazard rates. 
The main contribution of this study is that it applies results from organization and audit research to a phenomenon which has been hardly studied before, i.e., the spinoff. In particular, this chapter attempts to provide insight into the reasons why spinoffs take place. As mentioned before, the choice for the audit industry suits the spinoff issue very well. Furthermore, empirically, the high incidence of spinoffs in this chapter's time series guarantees a sufficient number of relevant observations.

The remainder of this chapter is organized as follows. In Section 6.2 previous research is discussed and hypotheses are formulated. More specifically, in this section a distinction is made between push factors (Section 6.2.1) and pull factors (Section 6.2.2). Section 6.2 .3 gives more details on the control variables, which will be used in the analyses. Then, in Section 6.3, the data are discussed and descriptive statistics are provided. Further, the method of analysis will be described. Section 6.4 reports the results. Section 6.5 presents a further discussion of the results. Finally, Section 6.6 concludes this chapter.

\subsection{Previous research and hypotheses}

\subsubsection{The push factors}

As indicated before, push factors represent the variables that determine whether or not auditors want to leave the firm. The fewer and/or the less forceful the push factors, the less likely it is that auditors want to leave the firm, and thus possibly start a spinoff. It is assumed that the desirability to leave is strongly dependent on the ability of an auditor to become partner of the audit firm. Becoming a partner is an important career goal for almost every auditor. In this chapter we therefore assume that creating a spinoff is mainly something associates do, rather than an initiative taken by partners. ${ }^{3}$ Bhamornsiri and Guinn (1991) argue that to become a partner the skills of the individual auditor are especially important. But also other firm-specific factors determine the career chances of an auditor within a firm. Hence, these variables mainly indicate the level of conflict and the lack of opportunities the auditor is facing within the current firm. It should be noted that the push variables only indicate whether or not auditors want to leave their firm. So the push variables help us to determine the switching behavior of auditors. The combination of push and pull variables will indicate when this switching behavior is indeed triggered into starting a new firm, so creating a spinoff.

3 Chapter 3 of the thesis of Meuwissen (1999) confirms the assumption that partners of an audit firm show little mobility. Thus, they almost never start their own business. 
It is mainly the literature on careers, organizational behavior and internal labor markets (e.g., Pfeffer, 1983; Pfeffer and Cohen, 1984; Wholey, 1985; Idson, 1989) that has paid attention to the factors that determine whether or not an employee wants to leave a firm. These factors are considered below.

The size of the firm is the first variable of interest. Idson (1989) points out that, in general, larger employers are better suited to provide various options for career advancement. Even more, they will use these options to protect high investments in employees and to evaluate the latter's performance. Furthermore, larger firms often have internal labor markets, which is associated with better career opportunities within the firm as well (Pfeffer and Cohen, 1984). Meuwissen (1998) uses the same arguments with respect to auditors in particular. He argues that the size of an audit firm may have a major influence on the career advancement of auditors. The reason for this is that large audit firms, unlike their small counterparts, provide their auditors with structured in-house professional development programs. Furthermore, they have more standardized career tracks leading to internal promotions for filling partner positions. Despite these predictions, Meuwissen (1998) finds that audit firm size is negatively related to the auditor's probability of advancing to partnership. So, his results indicate that for the audit industry size is negatively related to the opportunities for auditors within the audit firm. ${ }^{4}$ In his chapter, no alternative explanation for this result is provided. In addition, Aldrick (1998) showed that larger firms have lower partner/associate ratios, implying less chances for associates to become partners at larger firms. This suggests a nonlinear relationship between firm size and internal career opportunities. Because of the explorative nature of this study, we only conclude that size is expected to have an effect on the chance of a firm having a spinoff, but the sign and form of this effect is unknown. To leave most freedom to the estimation, we therefore include size as well as size squared without specifying the direction of their effects on the chances of a spinoff. Thus, the hypotheses on the chance of a spinoff are the following.

H1: Firm size has an effect, either positive or negative, on the chance of an audit firm having a spinoff.

H2: Firm size squared has an effect, either positive or negative, on the chance of an audit firm having a spinoff.

The second variable is the internal growth rate of the firm. Wholey (1985) studied growth for a comparable kind of professional service firm to the audit firm, i.e., the

4. It should be noted that becoming a partner of one of the large audit firms is of course more prestigious than becoming a partner of a small audit firm. 
law firm. ${ }^{5} \mathrm{He}$ finds that firm growth, in terms of the number of people employed, increases the incidence of internal promotion. Stewman and Konda (1983) and Rosenbaum(1984) investigated the effect of firm growth on promotion for organizations in general. They also find that firm growth, in terms of financial measures, increases the promotion chances for employees. The rationale behind this is that growing organizations need more employees in general, and more top-level employees in particular. Thus, based on previous research, it seems that firm growth is positively related with career opportunities. Therefore, the hypothesis about the influence of firm growth on spinoffs is the following.

\section{H3: The internal growth rate of an audit firm has a negative effect on the chance of the audit firm having a spinoff.}

Another factor, related to the firm growth issue, is a merger or acquisition. Much research has been conducted with respect to the consequences of mergers and acquisitions on employee behavior (e.g., Walsh, 1988; Buono and Bowditch, 1989; Cartwright and Cooper, 1992; Haveman and Cohen, 1994), all of which come to the conclusion that a merger or an acquisition increases staff turnover. The main reason for this is that mergers and acquisitions often transform organizational structures, systems, processes and cultures, resulting in conflict, uncertainty and negative feelings towards the organization. The involvement in a merger is an important factor in the Dutch audit industry because, especially since the 1970 s, merger activity in the audit industry has been considerable (de Hen et al., 1995). Furthermore, external growth through acquisitions is common in the audit industry. Because we made a distinction in the database between two or more firms merging, so forming a new firm, on the one hand, or a firm acquiring another firm on the other hand (which is calculated by the external growth rate), there will be separate hypotheses with respect to the acquisition and merger events. As mentioned above, research on mergers and acquisitions indicates that they increase conflict, and therefore staff turnover. Therefore, the hypotheses on the chance of a spinoff are the following.

H4: The external growth rate of an audit firm (i.e., by acquisition) has a positive effect on the chance of the firm having a spinoff.

H5: An audit firm's involvement in a merger has a positive effect on the chance of the firm having a spinoff.

5 Both the law firm and the audit firm have the typical partner-associate structure, and provide professional services. 
Research on general group behavior and (top) management teams has also paid attention to staff turnover (e.g., Pfeffer, 1983; van Olffen and Boone, 1997; Boone et al., 1998). Heterogeneity of the team members within a company affects the staff turnover rates within that company. Especially, as social-psychological studies have shown, differences between team members with respect to reference, attitudes and values lead to process losses, because of hampered communication, conflicts and power struggles (Pfeffer, 1983). The operational efficiency of diverse teams in performing their tasks is then threatened because much time and energy are required to overcome communication barriers and power games (Boone et al., 1998). So, heterogeneity within the audit firm can be considered to be one of the possible factors causing conflict, and therefore pushing auditors out of the firm. Based on this, hypotheses about the influence of heterogeneity within the audit firm can be developed. In the audit industry, in line with human capital theory (see Chapter 4), auditors formally differ on two characteristics, namely education and experience (Bröcheler et al., 1998). Heterogeneity in both characteristics is expected to be a push variable and, therefore, is predicted to have a positive effect on the chance of a spinoff. Therefore, the hypotheses are the following.

\section{H6: Heterogeneity of auditor education within an audit firm has a positive effect on the chance of the firm having a spinoff. \\ H7: Heterogeneity of auditor experience within an audit firm has a positive effect on the chance of the firm having a spinoff.}

This chapter's last push variable concerns a change in the demand for services of large audit firms. When product demand is increasing, industries tend to grow through the emergence of new firms or growth in the size of existing firms (Hachen, 1992). In the Dutch audit industry, one important law has influenced the demand for audit services of large audit firms (de Hen et al., 1995), which increased the opportunities for the auditors within these firms. Until 1970, Dutch legislation on annual accounts was mainly limited to Section 42 of the Code of Commerce. In here, only prescriptions for the annual accounts of a particular group of companies, the 'open' public companies ('open naamloze vennootschappen') were required (for a further description see Maijoor, 1991). The law of 1970 changed this by requiring disclosure of audited annual accounts for all public limited liability companies and large private limited liability companies. ${ }^{6}$ Thus, the law of 1970 influenced the opportunities within the parent firm for the auditors, therefore representing a (negative) push variable. This adjustment leads

6 The other main change in Dutch accounting law, the law of 1983, will be discussed in the section about pull factors. 
to the following hypothesis regarding the chance of experiencing a spinoff.

\section{H8: The law of 1970 has a negative effect on the chance of an audit firm having a spinoff.}

\subsubsection{The pull factors}

In contrast to the push factors, the pull factors are the variables that determine whether or not it is attractive for an auditor to go out into the market and establish a new firm. A parallel can be made with an argument pursued by Hachen (1992). He argues that whether or not employees quit when other employers offer them jobs, is a function of the potential gains to an employee from leaving. In this case, it are not the gains that auditors can get from other employers that matter, but rather the gains they can get from leaving their current firm and founding a spinoff. Factors that determine these gains are, for example, variables indicating the competitive intensity in the market and the height of entry barriers. Because both organizational ecology (e.g., Hannan and Freeman, 1989) and traditional industrial organization (e.g., Scherer and Ross, 1990) are concerned with industry dynamics, these theories are very helpful to select the possible pull variables.

Within industrial organization the dual market concept links high concentration (e.g., the C4) to high density (i.e., the number of firms in the market). Within the field of organizational ecology, resource partitioning theory (Carroll, 1985) also relates increasing concentration to increasing density. This link seems to hold in many industries. An explanation for this is that as large generalist firms compete for the market and increase their market share, niches for small specialist firms arise (see Chapter 5). These opportunities for new specialist firms will increase the density within the market. Thus, when large firms grow larger, new small firms get chances in the market. Most research indicates that this is true for product industries (e.g., Carroll, 1985; Carroll and Swaminathan, 1992). But recently Boone et al. (1999) found the same results for the Dutch audit industry as well (see Chapter 5). Here, large audit firms compete for the large clients, leaving the small clients to the small firms. The concentration ratio is thus one of the variables indicating market opportunities for new small firms. This leads to the following hypothesis regarding the chance of experiencing a spinoff.

H9: Increasing market concentration has a positive effect on the chance of an audit firm having a spinoff. 
Other population variables also give an indication of the opportunities within the market. These, too, are considered in both industrial organization and organization ecology research (Hannan and Freeman, 1989; Hannan and Carroll, 1992), and are intuitively of interest. The main variables that provide an indication of competitive intensity and chances within the market are the number of incumbent firms, so density, the interaction between concentration and density, and the number of entrants to and the number of exits from the market. First, density of the market is, in general, initially positively and later on negatively related to the opportunities within the market. More firms in the market initially indicate increasing legitimation, implying a profit-signaling effect. However, when density becomes higher, this produces tougher competition, and therefore less opportunities for new firms. Second, concentration multiplied by density is a measure of the competitive intensity within the industry. If both are high, then there is less space for all audit firms, and therefore tough competition throughout the market. Third, the number of entering firms in the market signals the market's opportunities. However, at the same time it indicates that there is new competition. Therefore, the influence of the number of entering firms is not unequivocal. Fourth, on the one hand, the number of exiting firms from the market indicates that there is stiff competition, implying constrained opportunities. On the other hand, the market improves, because established competitors leave the market place. Therefore, this influence is not unequivocal either. Together, the above leads to the following hypotheses regarding the chance of experiencing a spinoff.

H10: Density has a positive effect on the chance of an audit firm having a spinoff. H11: Density squared has a negative effect on the chance of an audit firm having a spinoff.

H12: The interaction of density with concentration has a negative effect on the chance of an audit firm having a spinoff.

H13: The number of firms entering the market has an effect, either positive or negative, on the chance of an audit firm having a spinoff.

H14: The number of firms exiting the market has an effect, either positive or negative, on the chance of an audit firm having a spinoff.

Another relevant variable is the demand for products, and thus - in our context - the demand for the services of small audit firms. When demand is increasing, industries tend to grow through the emergence of new firms or through the growth in the size of existing firms (Hachen, 1992). In the Dutch audit industry, one important law has influenced the demand for audit services from small audit firms (de Hen et al., 1995). Until 1983, audits for small and medium-sized private limited liability companies were conducted on a voluntary basis. But with the enactment of the law of 1983 abridged 
annual accounts became required for all small and medium-sized companies. Furthermore, all medium-sized firms had to audit their annual accounts (for a more detailed description see Maijoor, 1991). This led to an increase in the demand for small audit firms, thus making spinoffs more attractive. This change leads to the following hypothesis regarding the chance of experiencing a spinoff.

\section{H15: The law of 1983 has a positive effect on the chance of an audit firm having a spinoff.}

A last category of relevant variables, derived from a long tradition in industrial organization, pertains to entry barriers to the market. If there are entry barriers to a market, then it is difficult for new firms to enter the market, and therefore there are less opportunities for new firms in that market (Scherer and Ross, 1990). In previous audit research, a variable that was expected to be an important entry barrier, was measured by the professional code that prohibited advertising by audit firms. ${ }^{7}$ Because of this code it was very difficult for new audit firms to gain clientèle, and therefore to get established in the market. Research on the effects of demolished impediments to advertisement in the US showed that audit fees decreased, indicating that competition increased and entry barriers decreased (Maher et al., 1992; Sanders et al., 1995). In the Netherlands, there was also a professional code that prohibited advertisement. This code changed in 1987, allowing more advertising for audit firms (NIvRA, 1992). This diminished entry barriers, and therefore increased the opportunities for establishing a new audit firm. This leads to the following hypothesis regarding the chance of experiencing a spinoff.

H16: The changing professional code on advertisement in 1987, easing the requirements for advertising, has a positive effect on the chance of an audit firm having a spinoff.

Another important entry barrier is related to education and licensing. This barrier also changed during the evolution of the audit profession. Especially in the past 30 years, education requirements decreased, the number of institutions offering audit programs increased, and the average age of receiving the qualification decreased. These entry barriers, however, are not so much entry barriers for starting spinoffs, but rather entry barriers for individual auditors to enter the market in the first place. 


\subsubsection{The control variables}

After defining the push and pull variables, two other variables seem to be of interest. Therefore, these variables need to be included in the analysis as well. However, these two variables are treated as control variables because they do not represent changes in the opportunities for the auditors within the parent firm or changes in the opportunities within the market for audit services. The first control variable is the number of previous spinoffs that a firm has experienced. Analogous to the literature about interorganizational imitation, which is widespread in the economics and sociological literatures (e.g., Nelson and Winter, 1982; Powell and DiMaggio, 1991; Haunschild and Miner, 1997), it is expected that the experience of a firm with spinoffs can influence that firm's chance of experiencing another one (i.e., intra-organizational learning). This is mainly based on the argument that besides the auditors leaving the firm, the other auditors within the firm also experience the spinoff, and can get inspired by this. Therefore, this variable should be included in the analysis. The second control variable is the age of the firm. The number of spinoffs can be expected to be dependent on the age of the audit firm. Especially in the years directly after founding, i.e., the so-called honeymoon years, we expect that the chance of a spinoff is lower.

\subsection{Data and method}

\subsubsection{The data}

\section{Some characteristics of spinoffs}

In total, the data set contains 2,068 newly established audit firms that entered the audit market between 1880 and 1992 (see also Chapter 2, Section 2.4). Of these 2,068 firms that were founded, $372(17.99 \%)$ can be characterized as a spinoff. To gain more insight into the phenomenon of spinoffs in the audit industry a comparison between entry by spinoff and the other modes of entry (pure entry, entry by merger and entry by diaspora) with respect to eight characteristics of the firm is provided in Table 6.1. 
Table 6.1: A comparison between entry by spinoff and the other modes of entry ${ }^{8}$

\begin{tabular}{|c|c|c|}
\hline Variable & $\begin{array}{l}\text { Entry by spinoff } \\
\text { (Min./Max. (Mean /s.d.)) }\end{array}$ & $\begin{array}{l}\text { Other modes of entry } \\
\text { (Min./Max. (Mean/s.d.)) }\end{array}$ \\
\hline Number $^{9}$ & 356 & 1390 \\
\hline Longevity (in years) & $\begin{array}{l}1 / 73 \\
(9.10 / 9.50)\end{array}$ & $\begin{array}{l}1 / 81 \\
(13.30 / 12.54)\end{array}$ \\
\hline Year of founding & $\begin{array}{l}1894 / 1990 \\
(1972.55 / 19.22)\end{array}$ & $\begin{array}{l}1896 / 1990 \\
(1955.07 / 22.87)^{10}\end{array}$ \\
\hline Size at founding (in auditors) & $\begin{array}{l}1 / 18 \\
(1.72 / 1.88)\end{array}$ & $\begin{array}{l}1 / 516 \\
(3.10 / 21.76)\end{array}$ \\
\hline Size (in auditors) & $\begin{array}{l}1 / 165 \\
(3.21 / 7.27)\end{array}$ & $\begin{array}{l}1 / 516 \\
(4.04 / 21.83)\end{array}$ \\
\hline Education at founding ${ }^{11}$ & $\begin{array}{l}0 / 100 \\
(28.63 / 41.99)\end{array}$ & $\begin{array}{l}0 / 100 \\
(21.93 / 39.52)\end{array}$ \\
\hline Education & $\begin{array}{l}0 / 100 \\
(25.51 / 38.19)\end{array}$ & $\begin{array}{l}0 / 100 \\
(21.93 / 37.78)\end{array}$ \\
\hline Experience at founding ${ }^{12}$ & $\begin{array}{l}0.5 / 36 \\
(8.06 / 6.63)\end{array}$ & $\begin{array}{l}0 / 41 \\
(2.65 / 5.83)\end{array}$ \\
\hline Experience & $\begin{array}{l}0 / 56 \\
(12.39 / 8.22)^{13}\end{array}$ & $\begin{array}{l}0 / 66 \\
(10.29 / 8.83)\end{array}$ \\
\hline
\end{tabular}

8 Performing t-tests showed that none of the differences between the modes of entry are significant, due to large standard deviations.

9 In this table, due to missing values regarding some of the variables, the number of entries is smaller than the number in the initial data set.

${ }^{10}$ In this table, the earliest year of founding for other modes of entry is more recent than the earliest year of founding for entry by spinoff. The reason for this are missing values, especially in the earlier years of the time window.

11 Education is measured as the average percentage of academically educated auditors within the firm.

12 Experience is measured as the average number of years of experience in public practice of the auditors within the firm.

${ }^{13}$ On at least one occasion in our data, the minimum average experience of the auditors through time is 0 . The reason for this is the length of the observation spells. When auditors first appear in the database, they are treated as auditors without any experience. However, it is possible that they already started working in the firm before that year, but after the previous year of observation. This appears in our database in the case of a firm created by a spinoff. 
The average number of years of survival is somewhat less for firms founded by a spinoff than for the other entrants. This is partly caused by the fact that a spinoff is a rather modern phenomenon, implying that relatively many spinoffs still existed in 1992. Furthermore, the size of the firm founded by a spinoff is, on average, smaller than the size of the other new establishments. A reason for this is that spinoffs are always rather small, as opposed to firms which are founded by a merger. Furthermore, education is both slightly higher at founding and through time for entries by spinoff. Moreover, as expected, the average experience at founding is higher for firms founded by a spinoff, because the spinoff founders, by definition, already have experience within the market.

To gain more insight into the incidence of spinoffs compared to the other modes of entry, their numbers as a percentage of total density are presented in Figure 6.1.

Figure 6.1: Different modes of entry as a percentage of the total density ${ }^{14}$

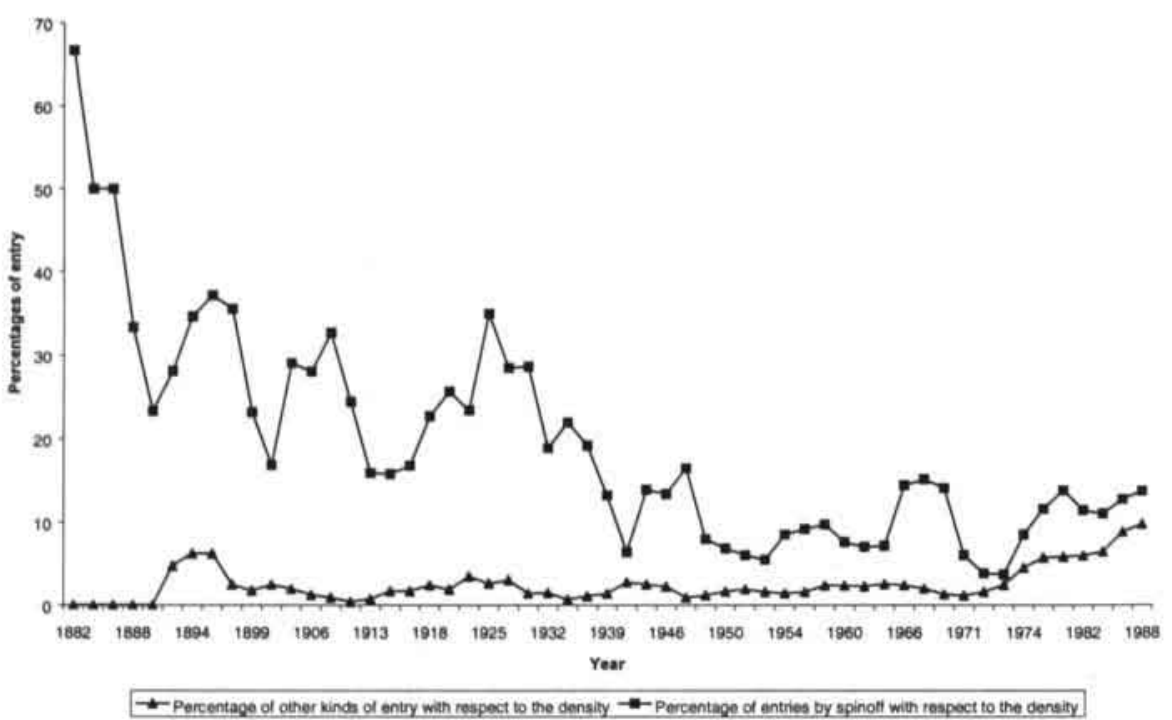

One can observe that especially during the last two decades the relative number of entries by means of spinoffs has increased considerably. Whereas, the relative number

14 In this figure the three-year moving averages are presented. This is done to get better insight into the trends of the different modes of entry. 
of other modes of entries shows a downward trend over the whole period.

\section{Coding rule}

This study concerns organizational spinoff. A spinoff is defined as a founding of a new audit firm by one or more auditors originating from another audit firm that continues to exist. ${ }^{15}$ Therefore, an audit firm has a spinoff if one or more auditors leave this firm to start a new firm of their own. However, it is not necessary that these leaving auditors start the firm alone. After all, they may immediately hire new auditors from outside the industry, hire people from other firms, or have the spinoff with people from other audit firms. Because of the necessity of the sample of firms to be able to have a spinoff at every year of observation, the sample only contains the parent firms that have more than one auditor in that particular year. As a result of this, there are in total 2,929 usable cases (i.e., observations, that is, periods of firms with more than one auditor). Furthermore, there were in total 372 spinoffs in the Dutch audit industry between 1880 and 1992, of which 298 contained information about all the variables used in the analyses.

\section{Variables}

The variables that are used in the analyses, are all linked to one of the hypotheses or the control variables. The first push variable is organizational size (1). The size of the audit firm is measured by counting the number of auditors affiliated with the firm. The second variable is size squared (2). The third push variable is the internal growth rate of the firm (3). The internal growth rate of the firm is measured as a percentage over the preceding period. The fourth variable is the external growth rate of the firm (4), which is the growth rate established through acquiring firms over the preceding period. The fifth push variable is a dummy indicating whether or not the audit firm was founded by a merger (5). This variable is coded with a 1 for the first four years after a merger, and with a 0 otherwise. Only the first four post-merger years are considered because it is expected that having a merger only influences the chance of a spinoff for a limited number of years. ${ }^{16} \mathrm{The}$ sixth and seventh push variables are the heterogeneity in terms of education (6) and experience (7) of the auditors within the firm. The heterogeneity of the average education is measured with a dummy variable. An audit firm is coded as heterogeneous in terms of education, if more than one-third

is One could argue that a spinoff by one person fundamentally differs from a spinoff by more persons, because the former is more likely to be a result of firing. We have tested this by conducting the analyses for both groups separately, but did not find significant differences. Therefore, no difference between these two types of spinoffs will be made in this chapter.

${ }^{16}$ Other time intervals were also considered. However, it appeared that for the first four years the effects were the strongest. 
but less than two-third of the auditors of the firm has an academic education. So, if the group of academic auditors is more or less equal to the group of non-academic auditors, the firm is considered to be heterogeneous (van Olffen, 1999). The heterogeneity of the average experience of the auditors of an audit firm is also measured with a dummy. To create this dummy, first the standard deviation of the experience within the firm is calculated. Then, the dummy is created by giving a 1 if a firm has a standard deviation above the average standard deviation for experience, and a 0 otherwise. The use of dummies is done to get robust indicators of high or low heterogeneity within the firm. One could argue that in this way information is lost. However, this method prevents non-substantial variation letting determine the effect. Further, as mentioned earlier, experience is measured through the average number of years of experience in public practice of the auditors of the firm. The eight push variable is a dummy indicating whether or not the firm existed after the law of 1970 (8). The law of 1970 is coded with a 1 for all existing firms between 1971 and 1975, because the opportunities resulting from this law will only exist for a limited number of years, i.e., until the market has adapted to these changes. This is done in accordance with earlier results concerning the audit market (see Maijoor, 1991 \& 1994). ${ }^{17}$

The first pull variable is market concentration (9). This variable is measured as the summed market share of the four largest audit firms (C4). This measure is chosen, because of the importance of the largest four firms in the Dutch audit market during the last few decennia. Furthermore, most spinoffs occurred during this time interval. The variable is taken one period lagged. This is done for all market variables, since (potential) firms need time to react to changing market conditions. The second pull variable is density (10), which is simply the number of firms in the market. The third variable is density squared (11). The fourth pull variable is concentration, measured by the $\mathrm{C} 4$, multiplied by density (12). The fifth and sixth pull variables are the number of firms entering (13), and exiting (14) the market. The seventh pull variable is a dummy indicating whether or not the firm existed after the law of 1983 (15). The law of 1983 is coded with a 1 for all existing firms between 1984 and 1988. The last pull variable is a dummy indicating the change in 1987 in the professional code on advertisement (16). This variable is coded with a 1 between 1988 and 1992. The effect of both the law and the professional code is only measured for a limited number of years for the same reason as for the law of 1970 .

Finally, the control variables are the number of previous spinoffs an audit firm experienced (17) and the age dependency of the firm (18). This age dependency covariate controls for the expectation that the chance of a spinoff is dependent on the age of

17 For all the law variables other time intervals and the possibility of a pre-regulation effect were considered as well, leaving a four-year post-regulation interval as the best option. 
the parent firm. Therefore, different constants for different ages will be included in the final model (see Chapter 5). The division in different age groups is based on different estimated models. In a first model, different coefficients are estimated for all ages. Then, based on the significance levels of these estimates for the different ages, new more general models are estimated. Based on the log likelihoods of these different models, and their number of periods involved, a final model is selected.

\section{Descriptive statistics of the variables}

As mentioned before, there are in total 2,929 usable cases and 298 usable spinoffs for the analyses. Table 6.2 provides an overview of the descriptive statistics of the independent variables. Furthermore, Table 6.3 contains a correlation matrix of the variables.

The internal growth rate ranges from declining with 340 percent to growing with 3,100 percent, which was caused by an outlier. The external growth rate lies between 0 and 340 percent. From the density, concentration, and entry and exit variables it can be seen that the market shows a lot of fluctuation. Finally, the audit firm's average age ranges from 1 year (caused by the growth variables) to 80 years of survival.

The correlations that have a value above 0.5 concern first, firm size and firm size squared. These are almost perfectly correlated. This indicates that there are few really large firms. Second, the higher correlations pertain to the number of previous spinoffs on the one hand, and size and size squared on the other hand. Unsurprisingly, larger firms have more spinoffs. Third, the dummy for the code on advertisement is highly correlated with density, density squared and the $\mathrm{C} 4$ multiplicated with density. The reason for this is that in the time episode that the code on advertisement was relaxed, these other variables are all high.

\subsubsection{The method}

In this chapter the event is the spinoff from an audit firm into the market, and the possible causes are the push and pull variables. As explained in Chapter 3, the hazard rate is the probability that an event will occur at a particular moment in time to a particular individual or collective entity, given that the entity is at risk at that time. In this study, the entity is the group of auditors that make up an audit firm. The hazard rate at a specific point in time is the probability that an audit firm will have a spinoff given that it is still at risk, i.e., still in the market and consisting of more than one auditor. The particular method of event history analysis used is the piece-wise constant rate model. This model does not assume an underlying time distribution (Blossfeld and Rohwer, 1995), but allows the age dependency to be determined by the data (see Chapter 3, Section 3.4.5). The main reason for choosing this type of model is that, 
Table 6.2: Descriptive statistics of the data ${ }^{18}$

\begin{tabular}{|c|c|c|c|c|c|}
\hline \# & Variable & Minimum & Maximum & Mean & $\begin{array}{l}\text { Standard } \\
\text { deviation }\end{array}$ \\
\hline \multicolumn{6}{|c|}{ Panel A: push variables } \\
\hline 1 & Size & 2 & 391 & 16.81 & 53.06 \\
\hline 2 & $\operatorname{Size}^{2} / 100$ & 0.04 & 1528.81 & 30.96 & 166.33 \\
\hline 3 & Internal growth rate ${ }^{19}$ & -340 & 3100 & 22.54 & 82.68 \\
\hline 4 & Growth rate through acquisition & 0 & 340 & 2 & 12.70 \\
\hline 5 & $\begin{array}{l}\text { Dummy growth through merger } \\
\text { (first } 4 \text { years) }\end{array}$ & 0 & 1 & 0.02 & 0.14 \\
\hline 6 & Dummy heterogeneity education & 0 & 1 & 0.07 & 0.25 \\
\hline 7 & Dummy heterogeneity experience & 0 & 1 & 0.39 & 0.49 \\
\hline 8 & Dummy law 1970 (1971-1974) & 0 & 1 & 0.15 & 0.36 \\
\hline \multicolumn{6}{|c|}{ Panel B: pull variables } \\
\hline 9 & $\mathrm{C} 4$ & 9.07 & 49.38 & 26.88 & 13.39 \\
\hline 10 & Density & 36 & 437 & 312.12 & 66.78 \\
\hline 11 & Density ${ }^{2} / 100$ & 12.96 & 1909.69 & 1018.8 & 363.90 \\
\hline 12 & C4*density & 6.46 & 168.90 & 85.77 & 46.20 \\
\hline 13 & Number of entrants & 2 & 255 & 61.42 & 48.69 \\
\hline 14 & Number of exits & 3 & 220 & 48.65 & 37.19 \\
\hline 15 & Dummy law 1983 (1984-1988) & 0 & 1 & 0.10 & 0.30 \\
\hline 16 & Dummy code on advertisement & 0 & 1 & 0.10 & 0.30 \\
\hline
\end{tabular}

Panel C: control variables ${ }^{20}$

17 Number of previous spinoffs

$\begin{array}{lll}0 & 25 & 0.91\end{array}$

2.58

18 The numbers in this table are only based on the 2,929 usable cases for the analyses. Therefore, the numbers can differ from those of Table 6.1.

19 Note that this percentage can become less than -100 , because the number of auditors within the firm can have increased within two observations. Furthermore, the internal growth rate is derived by subtracting the external growth rate from the overall growth rate.

${ }^{20}$ Here, the descriptive statistics regarding the age of the firm are not given, because the age is not as such included in the analyses. Instead the age dependency for different periods is introduced. 
Table 6.3: Correlation matrix of the variables

\begin{tabular}{|c|c|c|c|c|c|c|c|c|c|c|c|c|c|c|c|c|c|}
\hline$\|$ & 1 & 2 & 3 & 4 & 5 & 6 & 7 & 8 & 9 & 10 & 11 & 12 & 13 & 14 & 15 & 16 & 17 \\
\hline 1 & 1 & & & & & & & & & & & & & & & & \\
\hline 2 & 1 & 1 & & & & & & & & & & & & & & & \\
\hline 3 & .0 & .0 & 1 & & & & & & & & & & & & & & \\
\hline 4 & 0 & 0 & -1 & 1 & & & & & & & & & & & & & \\
\hline 5 & .0 & 0 & 0 & 1 & 1 & & & & & & & & & & & & \\
\hline 6 & 0 & 0 & 0 & .0 & .0 & 1 & & & & & & & & & & & \\
\hline 7 & . 1 & 1 & 0 & 0 & 0 & 0 & 1 & & & & & & & & & & \\
\hline 8 & 0 & 0 & .0 & .1 & .1 & 0 & 0 & 1 & & & & & & & & & \\
\hline 9 & .2 & .2 & 0 & 0 & .1 & 0 & .1 & 4 & 1 & & & & & & & & \\
\hline 10 & .1 & 1 & .0 & .0 & .0 & 0 & 0 & -1 & .1 & 1 & & & & & & & \\
\hline 11 & 1 & 1 & 0 & .0 & 0 & 0 & 0 & -.2 & .1 & 1 & 1 & & & & & & \\
\hline 12 & .2 & .2 & 0 & 0 & 0 & 0 & -11 & 3 & 9 & .4 & .4 & 1 & & & & & \\
\hline 13 & 0 & 0 & 0 & 0 & 0 & 0 & 0 & -2 & -1 & .4 & .4 & 1 & 1 & & & & \\
\hline 14 & -1 & .0 & 0 & .0 & .0 & 0 & 0 & 0 & -1 & .3 & $\cdot 2$ & $-I$ & $\cdot 2$ & 1 & & & \\
\hline 15 & 2 & .2 & .1 & 0 & 0 & 0 & -1 & -1 & .4 & 1 & 1 & .4 & 0 & -1 & 1 & & \\
\hline 16 & 2 & .2 & 0 & .0 & 0 & 0 & -1 & -1 & 3 & 5 & .7 & .6 & 3 & .1 & 0 & 1 & \\
\hline 17 & .8 & 8 & 0 & .0 & 0 & 0 & 2 & -.1 & .2 & 1 & 1 & .2 & 0 & 0 & 2 & 3 & 1 \\
\hline
\end{tabular}

to our knowledge, no prior research has been done with regard to spinoffs (in the audit industry), and therefore no well-founded assumptions about the age dependency can be made. Letting the data determining the effect then gives the best possible specification. Furthermore, by selecting this model, we choose for a continuous-time model because the process of having a spinoff is in reality of a continuous nature. Therefore, using a continuous model is preferable (see Chapter 3, Section 3.5).

\subsection{Results}

In order to test for the robustness of the results, we have done the analyses first by only considering the control variables (Model 1), then by only taking notice of the push variables (Model 2), then by only introducing the pull variables (Model 3), and finally by pooling the push and pull variables (Model 4). The results of these four models are shown in Table 6.4.

The results for Model 1 reveal that the control variables are of significant importance in explaining the occurrence of spinoffs. As expected, the number of previous spinoffs 
increases the chance of experiencing another spinoff. Moreover, the chance of a spinoff at different time ages initially decreases slightly and then increases up until 10 years of age. After that, it decreases again, finally reaching a stable level. The maximum at about 10 years of a firm's existence seems logical, because by that time most of the auditors who became employed in the first few years of the firm know their (lack of) opportunities within the firm.

The results for Model 2 show that the push variables give a significantly better explanation of the chance of a spinoff for an audit firm in the Dutch audit industry than a model with only the control variables (see the likelihood ratio test statistic of Models 1 and 2 compared). Four variables significantly influence the chance of a spinoff. Size and size squared together indicate that the influence of firm size on the chance of a firm having a spinoff is positive decreasing. The external growth rate (i.e., growth through acquisition) and the involvement in a merger also significantly influence the chance of a firm experiencing a spinoff. They both have a positive influence on the chance of a firm having a spinoff. Besides this, the estimates of the two control variables suggest that the number of previous spinoffs a firm experienced and the age of the firm remain important factors if the push factors are introduced. So, from Model 2, we can conclude that a larger size (but with a decreasing effect), higher growth through acquisition, and the involvement of an audit firm in a merger are more likely to push auditors out of the firm and into the market by creating spinoffs. Therefore, based on the results from the push model, we can conclude that Hypotheses $1,2,4$ and 5 are confirmed.

Model 3 shows that the pull variables, too, provide a significantly better explanation of the chance of a firm experiencing a spinoff than a model with only the control variables. Four variables significantly influence the chance of a spinoff. Density and density squared together indicate that the influence of density on the chance of a firm having a spinoff is positive decreasing. The third variable is the number of exits. When the number of exits increases, the chance of a spinoff decreases. This is because exits from the market seem to indicate a saturated market, so both higher density (but with a decreasing effect) and less exits signal more opportunities within the market for new firms. Finally, the fourth variable is the law of 1983. The law of 1983 increased the chance of a spinoff, indicating opportunities for smaller audit firms within the market. The control variables give roughly the same results as in Models 1 and 2 . Overall, from the pull model we can conclude that Hypotheses 10, 11, 14 and 15 are confirmed. 
Table 6.4: Results of the models (standard errors in parentheses) to explain organizational spinoffs

\begin{tabular}{llrl}
\hline$\#$ & Variable & Model 1 & \multicolumn{2}{c}{ Model 2 } \\
\hline \multicolumn{2}{l}{ Panel A: push variables } & 0.0254 & $(0.0020)^{* * *}$ \\
1 & Size & -0.0064 & $(0.0006)^{* * *}$ \\
2 & Size $^{2}$ & 0.0003 & $(0.0004)$ \\
3 & Internal growth rate & & \\
4 & $\begin{array}{l}\text { Growth rate through } \\
\text { acquisition }\end{array}$ & 0.0040 & $(0.0030)^{*}$ \\
5 & $\begin{array}{l}\text { Dummy growth through } \\
\text { merger (first 4 years) }\end{array}$ & 0.5229 & $(0.3986)^{*}$ \\
6 & $\begin{array}{l}\text { Dummy heterogeneity } \\
\text { education }\end{array}$ & 0.0888 & $(0.2781)$ \\
7 & $\begin{array}{l}\text { Dummy heterogeneity } \\
\text { experience }\end{array}$ & -0.0930 & $(0.1372)$ \\
8 & $\begin{array}{l}\text { Dummy law 1970 } \\
\text { (1971-1974) }\end{array}$ & -0.2486 & $(0.2188)$ \\
\hline
\end{tabular}

\section{Panel B: pull variables}

$9 \mathrm{C} 4$

10 Density

11 Density ${ }^{2} / 100$

$12 \mathrm{C} 4 *$ density

13 Number of entrants

14 Number of exits

15 Dummy law 1983

(1984-1988)

16 Dummy code on advertisement

\section{Panel C: control variables}

17 Number of previous spinoffs

18 Age of the firm

\begin{tabular}{llllll}
$0-2$ & $10-15$ & $-2.8172^{* * *}$ & $-3.0859^{* * *}$ & $-3.5263^{* * *}$ & $-3.6590^{* * *}$ \\
$2-4$ & $15-20$ & $-3.4299^{* * *}$ & $-3.2055^{* * *}$ & $-3.8730^{* * *}$ & $-3.6040^{* * *}$ \\
$4-6$ & $20-30$ & $-3.1156^{* * *}$ & $-3.4824^{* * *}$ & $-3.4705^{* * *}$ & $-3.7327^{* * *}$ \\
$6-8$ & $30-$ infinity & $-2.8370^{* * *}$ & $-3.6437^{* * *}$ & $-3.1905^{* * *}$ & $-3.6610^{* * *}$ \\
$8-10$ & & $-2.5963^{* * *}$ & & $-3.0261^{* * *}$ & \\
\hline
\end{tabular}

Significance: ${ }^{*} \mathrm{p}<.10,{ }^{* *} \mathrm{p}<.05$, and ${ }^{* * *} \mathrm{p}<.01$ (tested one- or two-tailed, where appropriate). 
Table 6.4 (Continued): Results of the models (standard errors in parentheses) to explain organizational spinoffs

\begin{tabular}{|c|c|c|c|c|c|}
\hline$\#$ & Variable & \multicolumn{2}{|c|}{ Model 3} & \multicolumn{2}{|c|}{ Model 4} \\
\hline \multicolumn{6}{|c|}{ Panel A: push variables } \\
\hline 1 & Size & & & 0.0212 & $(0.0023)^{* * *}$ \\
\hline 2 & Size $^{2}$ & & & -0.0057 & $(0.0006)^{* * *}$ \\
\hline 3 & Internal growth rate & & & 0.0002 & $(0.0004)$ \\
\hline 4 & $\begin{array}{l}\text { Growth rate through } \\
\text { acquisition }\end{array}$ & & & 0.0045 & $(0.0029)^{*}$ \\
\hline 5 & $\begin{array}{l}\text { Dummy growth through } \\
\text { merger (first } 4 \text { years) }\end{array}$ & & & 0.6834 & $(0.3945)^{* *}$ \\
\hline 6 & $\begin{array}{l}\text { Dummy heterogeneity } \\
\text { education }\end{array}$ & & & 0.0559 & $(0.2784)$ \\
\hline 7 & $\begin{array}{l}\text { Dummy heterogeneity } \\
\text { experience }\end{array}$ & & & -0.0957 & $(0.1366)$ \\
\hline 8 & $\begin{array}{l}\text { Dummy law } 1970 \\
(1971-1974)\end{array}$ & & & -0.3951 & $(0.2452)^{*}$ \\
\hline \multicolumn{6}{|c|}{ Panel B: pull variables } \\
\hline 9 & $\mathrm{C} 4$ & -0.0136 & $(0.0438)$ & -0.0390 & $(0.0450)$ \\
\hline 10 & Density & 0.0162 & $(0.0071)^{* *}$ & 0.0089 & $(0.0069)^{*}$ \\
\hline 11 & Density ${ }^{2} / 100$ & -0.0043 & $(0.0016)^{* * *}$ & -0.0031 & $(0.0016)^{* *}$ \\
\hline 12 & $\mathrm{C} 4 *$ density & 0.0087 & $(0.0151)$ & 0.0158 & $(0.0151)$ \\
\hline 13 & Number of entrants & 0.0012 & $(0.0017)$ & 0.0014 & $(0.0017)$ \\
\hline 14 & Number of exits & -0.0079 & $(0.0028)^{* * *}$ & -0.0076 & $(0.0028)^{* * *}$ \\
\hline 15 & $\begin{array}{l}\text { Dummy law } 1983 \\
(1984-1988)\end{array}$ & 0.6932 & $(0.1905)^{* * * *}$ & 0.4336 & $(0.1972)^{* *}$ \\
\hline 16 & $\begin{array}{l}\text { Dummy code on } \\
\text { advertisement }\end{array}$ & 0.1691 & $(0.3124)$ & 0.0717 & $(0.3028)$ \\
\hline
\end{tabular}

\section{Panel C: control variables}

17 Number of previous spinoffs

18 Age of the firm

\begin{tabular}{llllll}
$0-2$ & $10-15$ & $-4.1388^{* * *}$ & $-4.3471^{* * *}$ & $-3.3905^{* * *}$ & $-3.6065^{* * *}$ \\
$2-4$ & $15-20$ & $-4.4793^{* * *}$ & $-4.4761^{* * *}$ & $-3.6117^{* * *}$ & $-3.4809^{* * *}$ \\
$4-6$ & $20-30$ & $-4.2529 * * *$ & $-4.4886^{* * *}$ & $-3.2525^{* * *}$ & $-3.4247^{* * *}$ \\
$6-8$ & $30-$ infinity & $-4.0968^{* * *}$ & $-4.5749^{* * *}$ & $-3.0483^{* * *}$ & $-3.3122^{* * *}$ \\
$8-10$ & & $-3.7188^{* * *}$ & & $-2.7997^{* * *}$ & \\
\hline
\end{tabular}

Significance: ${ }^{*} \mathrm{p}<.10,{ }^{* *} \mathrm{p}<.05$, and ${ }^{* * *} \mathrm{p}<.01$ (tested one- or two-tailed, where appropriate). 
Table 6.4 (Continued): Results of the models to explain organizational spinoffs

\begin{tabular}{|c|c|c|c|c|}
\hline & Model 1 & Model 2 & Model 3 & Model 4 \\
\hline \multicolumn{5}{|l|}{ Panel D: statistics } \\
\hline Log likelihood only constant & -1143.5719 & -1143.5719 & -1143.5719 & -1143.5719 \\
\hline Log likelihood model & -917.4666 & -834.7542 & -861.019 & -808.6430 \\
\hline $\begin{array}{l}\text { Likelihood ratio test statistic } \\
\text { (Lrts) }\end{array}$ & $452.2106^{* * *}$ & $617.6354 * * *$ & $565.1058^{* * *}$ & $669.8578^{* * *}$ \\
\hline Lrts Model 1 to Model 2 & & $186.0830^{* * *}$ & & \\
\hline Lrts Model 1 to Model 3 & & & $112.8952^{* * *}$ & \\
\hline Lrts Model 1 to Model 4 & & & & $217.6472 * * *$ \\
\hline Lrts Model 2 to Model 4 & & & & $52.2224^{* * *}$ \\
\hline Lrts Model 3 to Model 4 & & & & $104.7520^{* * *}$ \\
\hline
\end{tabular}

Model 4, finally, pools all the variables. This model also provides a significantly better explanation of the chance of a spinoff than a model with only the control variables. Furthermore, the comparative log likelihood test statistics reveals significantly better results for Model 4 than for Models 2 and 3. Therefore, push and pull factors together provide a better explanation of the chance of a parent firm experiencing a spinoff than the other models. The results from this model are comparable to those for the two models discussed above. The only difference is that the law of 1970 also becomes of significant influence, by decreasing the chance of a firm experiencing a spinoff. Thus, a larger firm size (but with a decreasing effect), higher growth through acquisition, involvement of a firm in a merger, and operating outside the period of four years after the implementation of the law of 1970 all increase the chance that auditors are pushed out of the firm. Furthermore, a higher density (but with a decreasing effect) within the market, a lower number of exits and operating within four years after the implementation of the law of 1983 all increase the chance of a firm experiencing a spinoff by pulling auditors into the market. From this model, with both push and pull variables, we can conclude that Hypotheses 1, 2, 4, 5, 8, 11, 14 and 15 are confirmed. This is not true for Hypotheses 3, 6, 7, 9, 10, 12, 13, and 16 .

\subsection{Discussion}

In testing, it appears that both the heterogeneity measures are not of influence on the chance of an audit firm having a spinoff. A reason for this could be that in fact more heterogeneity in terms of education means that the different auditors are used to each other and work well together, and that heterogeneity in terms of experience means 
that the auditors differ more in terms of their career paths, and thus have more opportunities. Following this reasoning implies that when there are outliers in terms of education, and when the auditors are more the same in terms of experience, the chance of a spinoff should increase. Furthermore, the $\mathrm{C} 4$, the interaction between the $\mathrm{C} 4$ and density, the number of entrant firms, and the changing professional code on advertisement fail to influence the chance of a parent firm having a spinoff. It seems that standard resource partitioning arguments (Carroll, 1985) do not hold in the case of a spinoff. This can be seen from the fact that concentration does not have a positive effect on the chance of a parent firm having a spinoff. When we assume that spinoffs are usually small, a high concentration should increase their survival chances, and thus their founding rates (see Chapter 5). Also the unequivocal influence of the number of entering firms comes to the fore in the results. Furthermore, the entry barrier of the code on advertisement does not seem to be an entry barrier at all. All the other variables do, however, have an effect on the chance of a parent firm having a spinoff. These variables are discussed below.

- First, it seems that size has a decreasing positive influence on the chance of a parent firm experiencing a spinoff. This means that the chance of a spinoff increases at a decreasing rate with size. Larger firms have a higher chance of having a spinoff than small firms, but this chance increases less than proportional with size. The theory about internal labor markets seems to tell a story that nicely fits with the Dutch audit market.

- Second, the growth rate through acquisition does influence the chance of a parent firm having a spinoff. This result is supported by previous research, indicating that acquiring firms increases conflict within the firm.

- Third, the involvement in a merger has a positive influence on the chance of a firm having a spinoff. As can be seen from the theoretical part of this chapter, this result is supported by previous research, arguing that a merger increases conflict within the firm, so stimulating staff turnover.

- Fourth, the law of 1970 does indeed increase the opportunities for auditors within their firms, therefore decreasing the chance of the firm having a spinoff. This result, however, does not hold over the different models.

- Fifth, density seems to have a decreasing positive influence on the chance of a parent firm experiencing a spinoff. This result supports the theory that the market first produces a profit-signaling and legitimation effect, which gradually changes into a competition effect.

- Sixth, the number of exits seems to indicate the unattractiveness of the market for potential spinoffs, rather than the opportunity for spinoffs in the market.

- Finally, the law of 1983 indeed increased the opportunities in the market, implying that creating a spinoff became more attractive. 


\subsection{Concluding remarks}

This chapter is a first investigation to gain insight into the phenomenon of spinoffs within the audit industry. Based on previous research, two groups of variables have been distinguished, i.e., push variables and pull variables. The results indicate that both the push and the pull variables provide a good explanation of the chance of a firm experiencing a spinoff. Taken together, this implies that if both the opportunities in the auditors' current firms are low and the opportunities in the market for new firms are high, then it is most likely that auditors will leave their current firm and start their own firm, i.e., have their own spinoff.

Based on this chapter we would like to make five suggestions for further research.

- The first suggestion is to further explore the influence of the push and pull variables. This can be done by taking into account the other alternatives that auditors have next to staying with their current firm or creating their own firm by having a spinoff. These alternatives are switching from employer or going to work outside the public audit profession.

- The second suggestion is to explore what the interaction is between the push and the pull variables. What, in particular, makes people leave the firm and establish a spinoff? This can be tested by including interaction terms between certain push and pull variables

- The third suggestion is to further explore the influence of a merger event. The influence of a merger could also be dependent on size. Hereby, it could be important whether or not the merging parties are more or less of the same size. If they differ, then this could especially negatively influence the chances of the auditors of the relatively small firm within the new merged firm.

- The fourth suggestion is to further investigate the influence of heterogeneity in terms of education and experience within a firm. Hereby, the concept of what increases the chance of a spinoff most, i.e., heterogeneity or homogeneity, should be reconsidered. Furthermore, to gain better insight, it would be fruitful to only consider larger firms. The reason for this is that, for example, it is difficult to get a good measure of the heterogeneity of a two-person firm.

- The fifth suggestion is concerned with gaining additional and different insights into spinoffs. For example, the factors that determine the survival chances of an audit firm founded by a spinoff would provide more insight into this phenomenon. Furthermore, a comparative study between the survival chance of entries by spinoffs and other modes of entries would be fruitful. 



\section{Chapter 7}

\section{APPRAISAL}

\subsection{Introduction}

The aim of this thesis was to get insight into the factors that influence the long-term dynamics of firms within an industry, more specifically longevity, exit and spinoff. To achieve this aim, this thesis provided an empirical investigation into the Dutch audit market. First, as a foundation, Chapter 1 introduced the thesis, Chapter 2 discussed the database, and Chapter 3 dealt with the method of analysis. Then, Chapters 4 and 5 paid focused on two groups of factors that influence longevity, and thereby exit, of an audit firm. The two groups of factors are human capital factors and resource partitioning factors. Finally, Chapter 6 searched for factors that influence the chance of a parent firm experiencing a spinoff. Thus, the empirical chapters (Chapters 4, 5 and 6) all provide answers to important parts of the general research question, which together results into an overall picture of long-term firm dynamics in the Dutch audit industry.

The content of this final chapter is as follows. Section 7.2 summarizes the main results of the empirical chapters, and provides an overall answer to the research question of this thesis. Then, Section 7.3 points to the most important strengths and weaknesses of this study. Finally, Section 7.4 ends this thesis by putting forward the most important suggestions for further research.

\subsection{Overall conclusions}

This section provides the overall conclusions of this thesis. It starts by summarizing the general conclusions of Chapters 4,5 and 6 , respectively. Then, all the individual results are summarized in a table. Based on this table, the results are compared and integrated into an overall conclusion regarding long-term firm dynamics in the Dutch audit industry.

Chapter 4 investigates the influence of human capital on audit firm longevity and exit. It shows that the overall chance of exit decreases if the auditors' average education at founding is higher, and increases if the auditors' average experience through time is higher. Therefore, education at founding has a positive, and experience through time a negative effect on longevity. We also make a distinction between various modes of exit, because we expect that these modes all have different performance indications. 
Both a longer period until pure exit and a shorter period until an M\&A, are considered to be signs of higher performance when we take the mode of exit into account. The results are indeed more diverse. First, consider education. It seems that a higher education level, either at founding or during the lifetime of the audit firm, has a positive effect on the longevity of the firm until pure exit. This positive effect is absent in the case of exit as a result of M\&A. The findings are in line with the suggestion that a higher education level increases the performance of the audit firm: either the firm has a higher chance of survival or the firm has a higher chance of an M\&A exit. Second, the main results regarding the influence of experience on the longevity of audit firms can also be fine-tuned. On the one hand, experience at founding has a positive influence on the longevity of the audit firm until pure exit, and a negative influence on the longevity until M\&A exit. Hence, experience at founding has a positive effect on audit firm performance. On the other hand, higher experience levels during the lifetime of the audit firm, i.e., the aging of the personnel of the firm, has a negative effect on audit firm performance. The aging of personnel during the lifetime of the firm decreases survival chances until pure exit, and reduces chances of becoming a take-over target. Based on these results we developed a performance typology in which pure exit can be seen as a retirement destiny, a small firm merger as an experience trap, a big firm merger as an education acquisition, and exit by diaspora as a career move.

Chapter 5 investigates the influence of the market's concentration ratio on the longevity, and thereby exit, of small and large audit firms. This chapter learns us that the mortality rate for single proprietorships (and small firms) decreases with rising concentration but increases for large( $\mathrm{r}$ ) firms. Therefore, resource partitioning processes are clearly present in the Dutch audit market. Moreover, these processes primarily operate on the survival chances of single proprietorships, by improving these. An explanation for this is that when concentration increases, a separation in the market evolves into a small-firm niche and a large-firm segment. This, in turn, decreases the force competition from the large to the small firms. When we make a distinction between the pre-law period (before 1971) and the post-law period (from 1971 on), the results show strong and significant resource partitioning effects for the period before 1971 but not for the later period. Interestingly, after the major regulations were instituted, the resource partitioning process apparently came to an end. This indicates that competition is indeed the driving force behind the resource partitioning process. To summarize, our findings suggest that the mortality rate of specialist and generalist audit firms in the Netherlands were indeed shaped by resource partitioning processes. With these results we show that resource partitioning processes also take place in a professional service market.

Chapter 6 analyses the factors that influence the chance of a parent firm having a spinoff. It illustrates that both push and pull variables provide a good explanation 
of this chance. Taken together, this implies that if both the opportunities within the auditors' current firms are low and the opportunities in the market for new firms are high, it is more likely that auditors will leave their current firm and start their own firm, i.e., have their own spinoff. More specifically, a larger firm size (but with a decreasing effect), higher growth through acquisition, involvement of a firm in a merger, and operating outside the period of four years after the implementation of the law of 1970 all increase the chance that auditors are pushed out of the firm. Furthermore, a higher density (but with a decreasing effect) within the market, a lower number of exits and operating within four years after the implementation of the law of 1983 all increase the chance of a firm experiencing a spinoff by pulling auditors into the market.

To compare and integrate the results of the three empirical chapters, an overall perspective is needed. Therefore, Table 7.1 provides an overview of the results regarding all tested variables in the empirical chapters. When we integrate the results of Chapters 4 and 5 we get a good indication of which factors explain firm longevity, and thereby exit. First of all, the general firm characteristics that influence longevity are the age and size of the firm. From the model of Chapter 4 we can conclude that the age of the firm has a positive influence on the chance of the firm exiting the market. However, when we refine this variable into a fine-grained age dependency estimation, this relation is fine-tuned into one with first a negative influence on the chance of an exit, and later on a positive influence on the chance of an exit. This implies that when firms are established, their survival chances initially get better, but after some time this switches into a negative age effect, probably because of the many single-proprietorships. Furthermore, both Chapters 4 and 5 indicate that if the size of the firm is larger, the chance of an exit is smaller. So, larger firms are more stable competitors within the market. Second, the human capital variables that are of influence are the mean education at founding and the mean experience at founding and through time. Education at founding and experience at founding (only for Chapter 5) have a negative influence on the chance of a firm having an exit. So, human capital of the founders positively influences the longevity of the firm. However, the influence of experience through time is in the exact opposite direction. More experience through time increases the chance of a firm exiting the market. This is probably a retirement effect, because of the many single proprietorships in the Dutch audit market. With the retirement of a single proprietor, the firm as a consequence also exits the market. Third, an historical event that is of influence is World War II. This effect has partly been explained by the fact that during World War II the German regime demanded audit services. So, the firms that existed at the beginning of this period had a high chance of survival. 
Table 7.1: Results from the three empirical chapters compared

\begin{tabular}{|c|c|c|c|}
\hline Variable & $\begin{array}{c}\text { Chapter } 4 \\
\text { longevity/exit }\end{array}$ & $\begin{array}{c}\text { Chapter } 5 \\
\text { longevity/exit }\end{array}$ & $\begin{array}{c}\text { Chapter } 6^{1} \\
\text { spinoff }\end{array}$ \\
\hline Age of the firm & $(+)$ & & \\
\hline Age dependency of the firm & & $(-1+)$ & $(-1+1-)$ \\
\hline Density/100 & $(+)$ & $(+)$ & $(+)$ \\
\hline Density ${ }^{2} / 100$ & $(-)$ & $(-)$ & $(-)$ \\
\hline Number of entrant firms & NS & NS & NS \\
\hline Number of new auditors & NS & NS & \\
\hline Number of exits & & & $(-)$ \\
\hline Number of previous spinoffs & & & $(+)$ \\
\hline Existence at begin WWII & $(-)$ & $(-)$ & \\
\hline Law 1970 (until 1983) & NS & NS & \\
\hline Law 1970 (1971-1974) & & & $(-)$ \\
\hline Law 1983 & NS & NS & \\
\hline Law 1983 (1984-1988) & & & $(+)$ \\
\hline Dummy code on advertisement & & & NS \\
\hline Education at founding $/ 100$ & $(-)$ & $(-)$ & \\
\hline Change in education/100 & NS & NS & \\
\hline Dummy heterogeneity education & & & NS \\
\hline Experience at founding & NS & $(-)$ & \\
\hline Experience & $(+)$ & $(+)$ & \\
\hline Dummy heterogeneity experience & & & NS \\
\hline $\mathrm{C} 4$ & NS & $(+)$ & NS \\
\hline $\mathrm{C} 4 *$ Density & & & NS \\
\hline Size of the firm & $(-)$ & & $(+)$ \\
\hline $\mathrm{Size}^{2}$ & & & $(-)$ \\
\hline Dummy single proprietorship & & $(+)$ & \\
\hline Log size & & NS & \\
\hline $\mathrm{C} 4 *$ single proprietorship & & $(-)$ & \\
\hline $\mathrm{C} 4 * \log$ size & & NS & \\
\hline Internal growth rate & & & NS \\
\hline Growth rate through acquisition & & & $(+)$ \\
\hline Dummy growth through merger & & & $(+)$ \\
\hline
\end{tabular}

Note: NS indicates a non-significant, $(+)$ a positive and $(-)$ a negative association with the hazard rate. Furthermore, a blank space indicates that the variable was not tested.

1 For all three chapters the most general and complete models are compared; these are Model $1 \mathrm{~b}$, Model d, and Model 4 for Chapters 4, 5 and 6, respectively. 
But also the unavailability of data during the war could have influenced this. Fourth, the market characteristics that are of influence are the density measures. The density variables have a positive decreasing effect on the chance of exit. So, if the density increases, the chance of exit increases as well, but this effect is less than linear. Fifth, the resource partitioning variables that have an impact, are the concentration ratio and its interaction with the dummy for single proprietorships. When concentration is high, the chance of exit in general increases. However, this chance decreases for small firms.

When we integrate the results of Chapters 4, 5 and 6 we can conclude the following regarding long-term firm dynamics in general. First, when audit firms are still relatively young (up until approximately 12 years of age), their chance of an exit is decreasing, while their chance of having a spinoff is increasing (from approximately 2 to 10 years of age). However, when they get older, these chances change. So, when the audit firm is strong in the sense of featuring a high chance of survival, the chance of this firm experiencing a spinoff is also large. Second, when density increases, the chance of a firm having an exit is positive decreasing, while higher density decreases the chance of a firm experiencing a spinoff. So, the chance of an exit increases non-linearly, while the chance of a spinoff decreases when density gets high. Third, the size of the firm also has an effect on both the chance of longevity and spinoffs. Firm size has a positive decreasing effect on the chance of a firm having a spinoff, while it has a decreasing effect on the chance of that firm exiting the market. So, the chance of a spinoff increases but non-linearly, while the chance of an exit decreases with size. Hence, we can conclude that the long-term dynamics in the Dutch audit industry are especially influenced by the age of the firm, firm size and market density. These variables appear to have a similar impact on both longevity and the chance of a firm having a spinoff. Therefore, audit firms that are strong in the sense of having high chances of survival within the market, also have a higher chance of producing one or more spinoffs. On top of this, the individual dynamic processes (i.e., longevity, exit and spinoff) of course also have their own variables of influence (see Table 7.1, and the conclusions of Chapters 4, 5 and 6).

\subsection{Strengths and weaknesses}

Every study has its strengths and weaknesses. The most important strengths of this thesis are the following.

1. The data set which is used in this thesis is basically a panel data set. The database covers a very long period, from 1880 until 1992. This makes it possible to estimate general relationships that hold for the Dutch audit industry as a whole through 
a long period of time.

2. The data set includes almost the complete population of Dutch audit firms from the very beginning of the industry. Only in the first decades some data are missing. This near completeness of the database of Dutch audit firms ensures that the results from the analyses are more reliable and more generally applicable.

3. The integration of different research streams - particularly industrial organization, organizational ecology and audit market research - contributes to a more complete picture regarding long-term firm dynamics.

4. The Dutch audit industry is comparable to audit industries in other countries (see Chapter 5, Section 5.3.1), as well as to other professional service industries (see Chapter 6, Section 6.2.1). Therefore, this thesis contributes to an understanding of the dynamics in not only the Dutch audit industry, but in other audit and professional service industries as well.

5. The rich education and experience data at the auditor level permits us to open the black box of the audit firm by constructing human capital variables at the firm level.

The most important weaknesses of this thesis are the following.

1. Due to the long period under study, not much detailed information about the individual firms is available. Therefore, this thesis provides rather robust results regarding long-term firm dynamics instead of very specific findings regarding one sub-subject. For example, when testing the influence of human capital on firm longevity, only education and experience can be considered, and crudely measured. Other possible variables, like for example personality traits, can not be included. So, a long period under study usually implies not very detailed but general results that hold over a long period of time.

2. The analyses are partly dependent on the decision rules that are used during data construction. For example, the decisions about what mode of entry or exit a firm has, or about what a large and what a small firm is, are all subject to the rules used. Therefore, the use of rules not only incorporates consistency, but subjectivity as well.

3. Not all long-term firm dynamics are part of this thesis. Furthermore, not all possible variables of influence have been tested (see also weakness 1). Thus, this thesis is not exhaustive with respect to analyzing long-term firm dynamics. For example, firm founding is not considered in this thesis. 


\subsection{Suggestions for further research}

The suggestions provided in this section are partly taken from the suggestions already given in Chapters 4, 5 and 6, and partly of a general nature. The suggestions are divided into three categories: suggestions that elaborate on the research issues of this thesis, suggestions that explore other aspects of long-term firm dynamics and suggestions that go into non-firm dynamics research.

\subsubsection{Suggestions that elaborate on the research issues of this thesis}

\section{Suggestions with respect to longevity / exit}

A first suggestion related to research into firm longevity and exit is to further explore the variables that are or may be of influence on these events. In Chapters 4 and 5 of this thesis variables derived from industrial organization, organizational ecology (including resource partitioning theory), and human capital theory are already used side by side in explaining firm longevity and thereby exit. However, the relations between the variables derived form these theories can be further explored. For example, how do the human capital variables influence the density processes. A second suggestion is to investigate whether firms with different modes of entry have different longevity prospects. For example, do firms that have an entry by diaspora have the same longevity prospects as firms that have a pure entry. A third suggestion is to explore the influence of a fairly new development, the separation of ownership and control of audit firms, on the longevity and exit of these firms.

\section{Suggestions with respect to human capital variables}

One of the dominant production factors of an audit firm is the human capital embodied in the firm's auditor associates and partners. Therefore, the analyses of Chapter 4 may be expanded by introducing more and more detailed human capital features. In this context, for example, the argument of Pennings et al. (1998) that audit firm performance may well be explained by a firm's bundle of auditor - client network linkages is worthwhile exploring. This would imply collecting and investigating data on the client networks of audit firms.

\section{Suggestions with respect to resource partitioning theory}

First, more investigations into the relation between the dynamics of organizational populations on the one hand and the timing and form of legislation and regulation on the other hand are required. As mentioned in Chapter 5, our results suggest that the ecological process is affected by law. Of course, we need much more insight into the political processes behind these legal changes to confirm (or reject, for that matter) 
this speculation. Second, the interesting distinction within resource partitioning between generalism and specialism, between competing for the center of the market and differentiation away toward the market's periphery, deserves more attention. On the one hand, more research should make it possible for resource partitioning theory to identify and define the important dimensions along which firms 'generalize' in different industries. In the context of the audit industry, again an analysis of the client portfolio of large versus small firms (over time) might be helpful. On the other hand, research should focus on the dynamics of the resource partitioning process itself. That is, more insight is needed into how scale and scope-driven partitioning processes, causing a dual market structure, relate to the processes that happen within the generalist-segment and the specialist-niche (i.e., the second-order within-segment competition). In this way, the reasons behind the processes of generalists specializing and specialists generalizing could be uncovered.

\section{Suggestions with respect to the performance typology}

The performance typology which is developed in Chapter 4, is of an explorative nature only. The typology may be brought to perfection by introducing other and/or fine-grained variables. For instance, what is the influence of the partner-associate distinction that is so dominant in the audit industry, and what explains the different growth (and decline) paths of audit firms? Furthermore, application of this typology to resource partitioning processes would be interesting. For instance, do pure survival rates improve and do the chances of an M\&A deteriorate?

\section{Suggestions with respect to spinoffs}

A first suggestion is to investigate the influence of heterogeneity in terms of education and experience within a firm. Hereby, the concept of what increases the chance of a spinoff most, i.e., heterogeneity or homogeneity, should be reconsidered. The second suggestion is to explore the interaction between certain push and pull variables. What, in particular, not only makes people leave the firm but also pushes them to establish a spinoff? This can be tested by including interaction terms between selected push and pull variables. For example, between the law of 1983, that pulls auditors into the market, and the size of the audit firm. The third suggestion is concerned with gaining additional and different insights into spinoffs. For instance, the factors that determine the survival chances of an audit firm founded by a spinoff would provide more insight into this phenomenon. Furthermore, as stated earlier, a comparative study between the survival chance of entries by spinoffs and other modes of entries would be fruitful. 


\subsubsection{Suggestions that explore other long-term firm dynamics}

In this thesis we explored some important processes in a firm's life. However, other important firm events have been ignored. For one, firm founding in general has not been explored. Therefore, to establish a complete picture of long-term firm dynamics, this would be an interesting issue to study as well. In addition, a comparative study between the different modes of entries would provide even more insight into firm founding.

Furthermore, as can be inferred from the data used in this thesis (see Chapter 2), M\&A's are fairly common in the Dutch audit industry. From this, and partly from Chapter 6, we can conclude that the processes that occur within a newly merged firm are very interesting, but under-studied until now. For example, it could be important whether or not the merging parties are more or less of the same size. For instance, if the partner's sizes differ, this could especially negatively influence the career chances of the auditors of the relatively small firm within the new merged firm. Therefore, research about merged firms is also an interesting suggestion for further research.

\subsubsection{Suggestions that go into non-firm dynamics research}

Besides considering the firm level, analyses at the individual auditor level can be fruitful to understand part of the dynamics in a professional service industry. A reason for this is that part of what happens to an audit firm, is a direct consequence of the professional career motives of the firm's auditors. Therefore, considering auditor decisions can provide more insight into the functioning of the Dutch audit market. For example, it would be interesting to consider the options auditors have when they leave a firm besides creating a spinoff. Acquiring knowledge about which factors are especially important for which decision, may deepen our understanding further. Moreover, future research may focus on disentangling the processes that underlie the performance classification of Chapter 4, since many of the suggestive interpretations are testable by focusing on the auditor-level career data. For example, what happens to the partners of the medium-sized firms that are acquired by a Big Five market leader?

To conclude, a large array of avenues for future research is available. In any case, these and other suggestions indicate the challenging nature of the study of audit industries along the lines suggested in this chapter. 



\section{REFERENCES}

Abbott, A. (1988) The System of Professions, Chicago: University of Chicago Press.

Aldrick, Ph. (1998) 'Money-Go-Round: Survey: The Netherlands', International Accounting Bulletin, 232, 8-11.

Alford, M.R., Strawser, J.R., and Strawser, R.H. (1990) 'Does Graduate Education Improve Success in Public Accounting?', Accounting Horizons, 4, 69-76.

Allison, P. D. (1982) 'Discrete-Time Methods for the Analysis of Event Histories', in:

Leihardt, S., Sociological Methodology, San Fransisco: Jossey-Bass, 61-98.

Allison, P. D. (1984) Event History Analysis: Regression for Longitudinal Event Data, Sage Publications.

Barnett, W.P., and Carroll, G.R. (1987) 'Competition, and Mutualism Among Early Telephone Companies', Administrative Science Quarterly, 30, 400-421.

Bates, T. (1990) 'Entrepreneurial Human Capital Inputs, and Small Business Longevity', Review of Economics, and Statistics, 72, 551-559.

Benston, G.J. (1985) 'The Market for Public Accounting Services: Demand, Supply, and Regulation', Journal of Accounting, and Public Policy, 4, 33-79.

Bhamornsiri, S., and Guinn, R.E. (1991) 'The Road to Partnership in the "Big Six" Firms; Implications for Accounting Education', Issues in Accounting Education, 6, 9-24.

Blossfeld, H.-P., and Rohwer, G. (1995) Techniques of Event History Modeling: New Approaches to Causal Analysis, Mahwah, NJ: Lawrence Erlbaum.

Bonner, S.E., and Lewis, B.L. (1990) 'Determinants of Auditor Expertise', Journal of Accounting Research, 28, 1-20.

Bontridder, D.G.F. de (1997) 'Concurrentiebeding aan Banden', Accountant-Adviseur, $10,15-18$.

Boone, C., Bröcheler, V.K., and Carroll, G.R. (1999) 'Custom Service: Application, and Tests of Resource Partitioning Theory Among Dutch Auditing Firms from 1896 to 1992', Forthcoming in Organization Studies.

Boone, C., Carroll, G.R., and Witteloostuijn, A. van (1999) 'Environmental Resource Distributions, and the Market Partitioning of Dutch Daily Newspaper Organizations', Paper Presented at the Academy of Management Meeting, Chicago, August.

Boone, C., Olffen, W. van, and Witteloostuijn, A. van (1998) 'Psychological Team Make-Up as a Determinant of Economic Firm Performance: An Experimental Study', Journal of Economic Psychology, 19, 43-73.

Boone, C., and Witteloostuijn, A. van (1995) 'Industrial Organization, and Organizational Ecology: the Potentials for Cross-Fertilization', Organization Studies, 16, 265-298.

Boone, C., and Witteloostuijn, A. van (1996) 'Industry Competition, and Firm Human Capital', Small Business Economics, 8, 347-364.

Boone, C., and Witteloostuijn, A. van (1999) 'A Synthesis of Resource Partitioning, and Sunk Cost Theories: Location Partitioning, Profile Differentiation, Scale Economies, 
and Organizational Performance in the Dutch Newspaper Industry in 1950-1994', Working Paper, University of Warwick, Warwick Business School.

Bröcheler, V.K., Maijoor, S.J., and Witteloostuijn, A. van (1998) 'Human Capital, and Audit Firm Survival', Paper Presented at the ISAR Conference, Sydney, June.

Brüderl, J., Preisendörfer, P., and Ziegler, R. (1992) 'Survival Chances of Newly

Founded Business Organizations', American Sociological Review, 57, 227-242.

Buijink, W.F.J. (1992) Empirical Financial Accounting Research: Compliance with Regulation, Distributional Properties of Financial Ratios, and Demand for External Auditing, Dissertation 92-5, Faculty of Economics, and Business Administration, University of Limburg, Maastricht, The Netherlands.

Buijink, W.F.J., Maijoor, S.J., and Meuwissen, R.H.G. (1998) 'Competition in Auditing: Evidence from Entry, Exit, and Market Share Mobility in Germany Versus The Netherlands', Contemporary Accounting Research, 15, 385-404.

Buijink, W.F.J., Maijoor, S.J., Witteloostuijn, A. van, and Zinken, M.H.W. (1995) The Evolution of the Structure of the Dutch Audit Industry; A Descriptive Study of the 1880-1990 Period, RL/MANOR/MARC, University of Limburg, July.

Buono, A.F., and Bowditch, J.L. (1989) The Human Side of Mergers, and Acquisitions;

Managing Collisions Between People, Cultures, and Organizations, Jossey-Bass Publishers, San Francisco, London.

Carroll, G.R. (1983) 'Dynamic Analysis of Discrete Dependent Variables: A Didactic Essay', Quality, and Quantity, 17, 425-460.

Carroll, G.R. (1985) 'Concentration, and Specialization: Dynamics of Niche Width in Populations of Organizations', American Journal of Sociology, 90, 1262-1283.

Carroll, G.R., and Hannan, M.T. (1995) 'Resource partitioning', in: Carroll, G.R., and Hannan, M.T. (eds), Organizations in Industry: Strategy, Structure, and Selection, New York: Oxford University Press, 215-221.

Carroll, G.R., and Swaminathan, A. (1992) 'The Organizational Ecology of Strategic Groups in the American Beer Brewing Industry from 1975 to 1990', Industrial, and Corporate Change, 1, 65-97.

Carroll, G.R., and Swaminathan, A. (1993) 'On Theory, Breweries, and Strategic Groups', Industrial, and Corporate Change, 2, 99-106.

Carroll, G.R., and Swaminathan, A. (1998) 'Why the Micro Brewery Movement?

Organizational Dynamics of Resource Partitioning in the American Brewing Industry after Prohibition', Paper Presented at the $14^{\text {th }}$ Meeting of the European Group of Organization Studies, Maastricht, July.

Carter, N.M., Stearns, T.M., Reynolds, P.D., and Miller, B.A. (1994) 'New Venture Strategies: Theory Development with an Empirical Base', Strategic Management Journal, 15, 21-41.

Cartwright, S., and Cooper, C.L. (1992) Mergers, and Acquisitions: The Human Factor, Butterworth-Heinemann, Oxford.

Choo, F. (1989) 'Expert-Novice Differences in Judgement/Decision Making Research', Journal of Accounting Literature, 8, 106-136. 
Choo, F., and Trotman, K.T. (1991) 'The Relationship Between Knowledge Structure, and Judgements for Experienced, and Inexperienced Auditors', The Accounting Review, 66, 464-485.

Christ, M.Y. (1993) 'Evidence on the Nature of Audit Planning Problem Presentations: an Examination of Auditor Free Recalls', The Accounting Review, 68, 304-322.

Craswell, A.T, Francis, J.R., and Taylor, S.L. (1995) 'Auditor Brand Name Reputations, and Industry Specializations', Journal of Accounting, and Economics, 20, 297-322.

Danos, P., and Eichenseher, J.W. (1986) 'Long-Term Trends Toward Seller Concentration in the U.S. Audit Market', The Accounting Review, 61, 633-650.

Davis, J.S., and Solomon, I. (1989) 'Experience, Expertise,, and Expert-Performance Research in Public Accounting', Journal of Accounting Literature, 8, 150-164.

DeAngelo, L.E. (1981) 'Auditor Size, and Audit Quality', Journal of Accounting, and Economics, 3, 183-199.

Delacroix, J., Swaminathan, A., and Solt, M.E. (1989) 'Density Dependence versus Population Dynamics: an Ecological Study of Failings in the Californian Wine Industry' American Sociological Review, 54, 245-262.

Dobrev, S. (1997) The Dynamics of the Bulgarian Newspaper Industry in a Period of Transition, Unpublished Doctoral Thesis, Stanford University, Department of Sociology.

Eichenseher, J.W., and Danos, P. (1981) 'The Analysis of Industry-Specific Auditor Concentration: Towards an Explanatory Model', The Accounting Review, 56, 479 492.

Francis, J.R., and Stokes, D.J. (1986) 'Audit Prices, Product Differentiation,, and Scale Economies: Further Evidence from the Australian Market', Journal of Accounting Research, 24, 383-393.

Freeman, J., and Lomi, A. (1994) 'Resource Partitioning, and Foundings of Banking Cooperatives in Italy', in: Baum, J.A.C., and Singh, J. (eds), The Evolutionary Dynamics of Organizations, New York: Oxford University Press, 269-293.

Greene, W.H. (1990) Econometric Analysis, Prentice Hall, Englewood Cliffs, New York.

Gwilliam, D. (1987) A Survey of Auditing Research; Research Studies in Accounting, The Institute of Chartered Accountants in England, and Wales, Prentice-Hall International.

Hachen, Jr. D.S. (1992) 'Industrial Characteristics, and Job Mobility Rates', American Sociological Review, 57, 39-55.

Hannan, M.T. (1988) 'Social Change, Organizational Diversity, and Individual Careers', in: Riley, M. (ed), Social Change, and the Life Course, 1, Newbury Park, California: Sage, 161-174.

Hannan, M.T. (1998) 'Rethinking Age Dependence in Organizational Mortality: Logical Formalizations', Paper Presented at the $14^{\text {th }}$ Meeting of the European Group of Organization Studies, Maastricht, July 1998.

Hannan, M.T., and Carroll, G.R. (1992) Dynamics of Organizational Populations, New York: Oxford University Press. 


\section{REFERENCES}

Hannan, M.T., and Freeman, J. (1989) Organizational Ecology, Harvard University Press, Cambridge, London.

Haunschild, P.R., and Miner, A.S. (1997) 'Modes of Interorganizational Imitation: The Effects of Outcome Salience, and Uncertainty', Administrative Science Quarterly, 42, 472-500.

Haveman, H.A., and Cohen, L.E. (1994) 'The Ecological Dynamics of Careers: The Impact of Organizational Founding, Dissolution,, and Merger on Job Mobility', American Journal of Sociology, 100, 104-152.

Haveman, H.A., and Nonnaker, L. (1998) Competition in Multiple Geographic Markets: The Impact on Growth, and Market Entry, Unpublished Manuscript, Cornell University.

Hen, P.E. de, Berendsen, J.G., and Schoonderbeek, J.W. (1995) Hoofdstukken uit de Geschiedenis van het Nederlandse Accountantsberoep na 1935, Assen: Van Gorcum.

Idson, T.L. (1989) 'Establishment Size Differentials in Internal Mobility, The Review of Economics, and Statistics, 71, 721-724.

Langendijk, H.P.A.J. (1990) 'Wisseling van Accountantskantoor: Een Fata Morgana in de Toekomst?', Maandblad voor Accountancy en Bedrijfseconomie, 64, 264-270.

Leeflang, P.S.H., Boxem, G., and Dijk, J.A. van (1992) 'De Markt voor Accountantsdiensten in Nederland (deel 1)', Maandblad voor Accountancy en Bedrijfseconomie, 66, 103-107.

Libby, R., and Frederick, D.M. (1990) 'Experience, and the Ability to Explain Audit Findings', Journal of Accounting Research, 28, 348-367.

Lomi, A. (1995) 'The Population, and Community Ecology of Organizational Founding: Italian Cooperative Banks, 1936-1989', European Sociological Review, 11, 75-98.

Maher, M.W., Tiessen, T., Colson, R., and Broman, A.J. (1992) 'Competition, and Audit Fees', The Accounting Review, 67, 199-211.

Maijoor, S.J. (1991) The Economics of Accounting Regulation: Effects of Dutch Accounting Regulation for Public Accountants, and Firms, PhD-Dissertation, Datawyse, Maastricht.

Maijoor, S.J. (1994) 'Economic Effects of Accounting Regulation for Public Accountants: Evidence from the Netherlands', Accounting, and Business Research, 24, 267-276.

Maijoor, S.J., Buijink, W.F.J., Meuwissen, R.H.G., and Witteloostuijn, A. van (1998) 'Towards the Establishment of an Internal Market for Audit Services within the European Union', European Accounting Review, 7, 655-674.

Maijoor, S.J., Buijink, W.F.J., Witteloostuijn, A. van, and Zinken, M.W.H. (1995) 'Long-Term Concentration in the Dutch Audit Market: The Use of Auditor Association Membership Lists in Historical Research', Abacus, 31, 152-177.

Maijoor, S.J., and Meuwissen, R.H.G. (1993) 'Mobility of Auditors, and the Nature of Audit Services: Exploratory Evidence from the Dutch Audit Market', MARC Research Memorandum, University Maastricht. 
Maijoor, S.J., and Witteloostuijn, A. van (1996) 'An Empirical Test of the ResourceBased Theory: Strategic Regulation in the Dutch Audit Industry', Strategic Management Journal, 17, 549-569.

Meuwissen, R.H.G. (1992) 'De Meting van de Omvang van Accountantskantoren: Een Empirische Studie', MARC Research Memorandum, MARC 92/016, Maastricht: MARC.

Meuwissen, R.H.G. (1998) 'Career Advancement in Audit Firms: An Empirical Study of University-Educated, and Non University-Educated Dutch Auditors', Accounting Education, 7, 35-50.

Meuwissen, R.H.G. (1999) The Economics of Auditor Careers, and Audit Markets, Universitaire Pers Maastricht, Maastricht.

Meyer, J., and Rowan, B. (1977) 'Institutionalized Organizations: Formal Structure as Myth, and Ceremony', American Journal of Sociology, 83, 340-363.

Mock, T.J., and Turner, J.L. (1981) 'Internal Control Evaluation, and Auditor Judgment', Audit Research Monograph, 3, New York: AICPA.

Moizer, P., and Turley, S. (1989) 'Changes in the U.K. Market for Audit Services', Journal of Business Finance, and Accounting, 16, 41-53.

Nelson, R.R., and Winter, S.G. (1982) An Evolutionary Theory of Economic Change, Belknap Press of Harvard University Press.

NIvRA (1992) 'Opdrachtaanvaarding en Voorbereiding van de Controle', in: Elementaire Kennis Accountantscontrole, Hoofdstuk 5, Wolters-Noordhoff, Groningen, 97-98.

Olffen, W. van (1999) Team Level Locus of Control and Competitive Team Behavior, Universitaire Pers Maastricht, Maastricht.

Olffen, W. van, and Boone, C. (1997) 'The Confusing State of the Art in Top Management Composition Studies: A Theoretical, and Empirical Review', Research Memorandum NIBOR, NIBOR/RM/97/11.

Palmrose, Z. (1986) 'Audit Fees, and Auditor Size: Further Evidence', Journal of Accounting Research, 24, 97-110.

Parker, R.H. (1993) 'The Scope of Accounting History: A Note', Abacus, 29, 106-110.

Péli, G. (1998) 'Formalization of Resource Partitioning Theory', Paper Presented at the $14^{\text {th }}$ Meeting of the European Group of Organization Studies, Maastricht, July 1998.

Péli, G., and Nooteboom, B. (1997) 'Market Partitioning, and the Geometry of the Resource Space', Paper Presented at the Stanford Conference on Strategic Management, Stanford CA, February 1998.

Pennings, J.M., Lee, K., and Witteloostuijn, A. van (1998) 'Human Capital, Social Capital,, and Firm Dissolution', Academy of Management Journal, 41, 425-440.

Petersen, T. (1993) 'Recent Advances in Longitudinal Methodology', Annual Review of Sociology, 19, 425-454.

Petersen, T., and Koput, K.W. (1992) 'Time-Aggregation Bias in Hazard-Rate Models with Covariates', Social Methods, and Research, 21, 25-51.

Pfeffer, J. (1983) 'Organizational Demography', Research in Organizational Behavior, 5, 299-357. 
Pfeffer, J., and Cohen, Y. (1984) 'Determinants of Internal Labor Markets in Organizations', Administrative Science Quarterly, 29, 550-572.

Post, H., Wilderom, C., and Douma, S. (1998) 'Internationalization of Dutch Accounting Firms', European Accounting Review, 7, 697-708.

Powell, W. (1985) Getting Into Print, Chicago: University of Chicago Press.

Powell, W., and DiMaggio, P. (1991) The New Institutionalism in Organizational Analysis, University of Chigaco Press, Chicago.

Preisendörfer, P., and Voss, T. (1990) 'Organizational Mortality of Small Firms: The Effects of Entrepreneurial Age, and Human Capital', Organization Studies, 11, 107-129.

Previts, G.J., Parker, L.D., and Coffman, E.N. (1990) 'Accounting History: Definition, and Relevance', Abacus, 26, 1-13.

Rosenbaum, J.E. (1984) Career Mobility in a Corporate Hierarchy, Academic Press Inc., Orlando, Florida.

Sanders, G., Allen, A., and Korte, L. (1995) 'Municipal Audit Fees: Has Increased Competition Made a Difference?', Auditing: A Journal of Practice, and Theory, 14, 105-114.

Scherer, F.M., and Ross, D. (1990) Industrial Market Structure, and Economic Performance, Houghton Mifflin Company, Boston, Third Edition.

Schiff, A., and Dov Fried, H. (1976) 'Large Companies, and the Big Eight: An Overview', Abacus, 12, 116-124.

Schmalensee, R., and Willig, R. (1989) Handbook of Industrial Organization, Elsevier Science Publishers B.V., Amsterdam, New York, 2.

Seidel, M.-D. (1997) Competitive Realignment in the Airline Industry: A Dynamic Analysis of Generalist, and Specialist Organizations under Different Network Structures, Unpublished Doctoral Thesis, University of California at Berkeley, Haas School of Business

Siegel, P.H. (1987) 'Auditor Performance, and Educational Preparation: An Analysis', Issues in Accounting Education, 2, 127-140.

Siegel, P.H., Rigsby, J.T., and Leavins, J. (1992) 'An Analysis of the Relative Contribution of Experience/Education to the Professional Development of Auditors', Advances in Accounting, 10, 143-158.

Spiceland, J.D., Siegel, P.H., and George, C.R. (1992) 'Educational Preparation of Auditors, Promotion Time, and Turnover: A Survival Analysis', Advances in Accounting, 10, 61-76.

Stewman, S., and Konda, S.L. (1983) 'Careers, and Organizational Labor Markets: Demographic Models of Organizational Behavior', American Journal of Sociology, 88, 637-685.

Sutton, J. (1992) Sunk Costs, and Market Structure, The MIT Press, Cambridge, Massachusetts, London, England.

Swaminathan, A. (1995) 'The Proliferation of Specialist Organizations in the American Wine Industry, 1941-1990', Administrative Science Quarterly, 40, 653-680. 
Swaminathan, A. (1998) 'The Impact of Resource-Partitioning, and Mobility Barriers on the Evolution of Specialist Organizations in the American Wine Industry', Paper Presented at the Stanford Conference on Strategic Management, Stanford CA, February 1998.

Torres, J.C. (1995) The Dynamics of the UK Motor Industry: An Ecological Analysis. Unpublished Doctoral Thesis, Stanford University, Department of Sociology.

Tuma, N.B., and Brandon, M.T. (1984) Social Dynamics: Models, and Methods, Academic Press Inc., Orlando.

Vries, J. de (1985) Geschiedenis der Accountancy in Nederland, Assen: Van Gorcum.

Wade, J.B. (1996) 'A Community-Level Analysis of Sources, and Rates of Technological Variation in the Microprocessor Market', Academy of Management Journal, 5, 1218-1244.

Walsh, J.P. (1988) 'Top Management Turnover Following Mergers, and Acquisitions', Strategic Management Journal, 9, 173-183.

Wholey, D.R. (1985) 'Determinants of Firm Internal Labor Markets in Large Law Firms', Administrative Science Quarterly, 30, 318-335.

Wilensky, H. (1964) 'The Professionalization of Everyone', American Journal of Sociology, 70, 137-158.

Witteloostuijn, A. van, and Boone, C. (1999), 'A Game Theory of Organizational Ecology: A Model of Managerial Inertia, and Market Selection', Working Paper, University of Warwick, Warwick Business School.

Witteloostuijn, A. van, Boone C., and Carroll G.R. (1999), 'A Resource-Based Theory of Market Structure', Working Paper, University of Warwick, Warwick Business School.

Wright, A. (1988) 'The Comparative Performance of MBA's versus Undergraduate Accounting Majors in Public Accounting', The Accounting Review, 63, 123-136.

Yamaguchi, K. (1991) 'Event History Analysis', Applied Social Research Methods Series, 28, Sage Publications Inc., Newbury Park.

Yardley, J.A., Kauffman, N.L., Cairney, T.D., and Albrecht, W.D. (1992) 'Supplier Behaviour in the U.S. Audit Market', Journal of Accounting Literature, 11, 151-184. Zind, R.G., and Zéghal, D. (1989) 'Some Characteristics of the Canadian Audit Industry', Contemporary Accounting Research, 6, 26-47. 



\section{NEDERLANDSE SAMENVATTING}

Dit proefschrift handelt over ondernemingsdynamiek en de oorzaken daarvan. De algemene onderzoeksvraag van dit proefschrift luidt: Welke factoren verklaren de lange termijn dynamiek van ondernemingen binnen een industrie, meer specifiek levensduur, uittreding en afsplitsing? Het proefschrift maakt voornamelijk gebruik van empirische analyses om antwoorden op deze vraag te verkrijgen. Teneinde deze analyses te kunnen uitvoeren is ervoor gekozen om Nederlandse accountancy kantoren gedurende hun leven te volgen. In totaal is bijna de complete accountancy markt, vanaf het eerste kantoor in 1880, tot en met 1992 in kaart gebracht. Als theoretisch kader is gebruik gemaakt van drie theorieën die handelen over marktstructuren. Vanuit organisatie perspectief zijn dit industriële organisatie en organisatie ecologie, en vanuit accountancy perspectief "audit market" onderzoek. Op deze manier draagt dit proefschrift niet alleen bij aan inzicht in ondernemingsdynamiek, maar ook aan een integratie van verschillende perspectieven / theorieën.

Alvorens te beginnen aan de werkelijke analyses, behandelen Hoofdstukken 2 en 3 het databestand en de methode van analyse, "event history analysis". Hoofdstuk 2 begint met een korte beschrijving van de geschiedenis van de Nederlandse accountancy markt. Hierin wordt beschreven waarom het eerste accountantskantoor gesticht werd, en hoe de vraag, het aanbod en de regulering zich door de tijd hebben ontwikkeld. Daarna wordt ingegaan op het databestand. Aan bod hierbij komen de wijze van verzameling en de manier waarop het databestand is omgezet in een bestand dat geschikt is voor dynamisch onderzoek. Als laatste wordt in dit hoofdstuk meer inzicht gegeven in het databestand door beschrijvende statistieken betreffende de industrie, de accountantskantoren, de wijze van toe- en uittreding, en de grootte van de kantoren te verschaffen.

Hoofdstuk 3 gaat, zoals gezegd, in op de methode van analyse. Voor het verklaren van gebeurtenissen is "event history analysis" een goede methode. De afhankelijke variabele in deze methode is de "hazard rate". Dit is de kans dat een bepaalde gebeurtenis plaatsvindt op een bepaald tijdstip, gegeven dat de gebeurtenis op dat moment nog kan plaatsvinden. In dit hoofdstuk wordt deze methode uitgelegd. Voorts wordt ingegaan op bepaalde specificaties van deze methode, de modelkeuze en de test om de "goodness of fit" te bepalen, en op de belangrijkste potentiële knelpunten van de methode.

Hoofdstukken 4, 5 en 6 zijn de kernhoofdstukken van dit proefschrift, en bevatten de empirische analyses betreffende de onderzoeksvraag. Hoofdstuk 4 behandelt de vraag hoe het "human capital" van een kantoor de overlevingskansen van dit kantoor in de markt beïnvloedt. Hierbij wordt human capital gemeten met behulp van het gemiddelde opleidingsniveau en de gemiddelde ervaring, beide van zowel de oprichters als van de werknemers door de tijd. De invloed van human capital op de 
uittredingskansen van accountantskantoren blijkt als volgt te zijn. Als het gemiddelde opleidingsniveau van de oprichters hoger is, dan is de kans op uittreding lager. Als de gemiddelde ervaring van de werknemers door de tijd hoger is, dan is de kans op uittreding groter. Opleiding bij oprichting heeft dus een positief, en ervaring door de tijd een negatief effect op de levensduur van een kantoor. Er kan echter ook een uitsplitsing worden gemaakt naar verschillende soorten van uittreding. De soorten uittreding die we hierbij onderscheiden zijn pure uittreding, uittreding door fusie of overname (waarbij een onderscheid wordt gemaakt tussen een fusie of overname met tenminste een van de grote kantoren of alleen tussen kleine kantoren), en uittreding door diaspora (uiteenvallen van het kantoor). Hierdoor veranderen de resultaten. De resultaten met betrekking tot de opleiding zijn als volgt. Een hoger opleidingsniveau (zowel voor de oprichters als door de tijd) heeft een positief effect op de levensduur van een kantoor dat een pure uittreding heeft. Dit positieve effect is niet aanwezig bij kantoren die uittreden door fusie of overname. Deze resultaten stemmen overeen met onze verwachting dat een hoger opleidingsniveau de "performance" van een kantoor doet verhogen: of het kantoor heeft een grotere kans op overleving, of het kantoor heeft een grotere kans om te fuseren of overgenomen te worden. Met betrekking tot ervaring zijn de resultaten als volgt. Ervaring van de oprichters heeft een positieve invloed op het overleven van het kantoor tot het moment van pure uittreding, en een negatieve invloed op overleven tot een fusie of overname. Ervaring bij oprichting heeft dus ook een positief effect op de performance van een kantoor. Echter, ervaring door de tijd heeft een negatief effect op de performance van een accountantskantoor. Deze variabele verlaagt namelijk de overlevingskansen tot het moment van pure uittreding en het verhoogt de overlevingskansen tot het moment van een fusie of overname. Vervolgens is, gebaseerd op deze resultaten, een performance typologie gemaakt. Hierbij wordt pure uittreding gekarakteriseerd door een pensioensbestemming (retirement destiny), een fusie tussen kleine kantoren een ervaringsval (experience trap), een fusie met een groot kantoor een opleidingsovername (education acquisition), en een uittreding door diaspora een carrierestap (career move).

Hoofdstuk 5 behandelt de vraag hoe de marktconcentratie (dit is het gezamenlijk marktaandeel van de $n$ grootste kantoren) in relatie tot de kantoorgrootte de overlevingskansen van een kantoor beïnvloedt. Het theoretisch kader dat ten grondslag ligt aan dit hoofdstuk is "resource partitioning theory". Deze theorie zegt dat als de concentratie in een markt toeneemt, er een spreiding in de markt zal ontstaan tussen een aantal grote met elkaar in het centrum van de markt concurrerende kantoren, en een groot aantal kleine met elkaar in een niche concurrerende kantoren. Hierdoor zullen de overlevingskansen van grote kantoren kleiner worden en van kleine kantoren groter. De toepassing van deze theorie is tot op heden echter alleen voor een aantal produktie-industrieern aangetoond. In dit hoofdstuk zal de theorie getoetst worden 
voor een professionele dienstenindustrie. De resultaten laten zien dat resource partitioning aanwezig is in de Nederlandse accountancy markt. Verder blijkt dat dit proces vooral voor de eenmanskantoren aanwezig is, waarbij het de overlevingskansen voor deze kantoren dus vergroot. Als de analyses voor twee sub-periodes worden uitgevoerd, te weten de periode voor de regulering (voor 1971) en de periode na de regulering (vanaf 1971), dan blijkt dat het resource partitioning proces vooral voor de regulering heeft plaatsgevonden. Hieruit blijkt dat ook in deze industrie de concurrentie klaarblijkelijk het resource partitioning proces heeft veroorzaakt, en niet zoals vaak gesuggereerd wordt, de regulering. Er kan dan ook geconcludeerd worden dat resource partitioning processen ook in professionele dienstenindustrieën voorkomen.

Hoofdstuk 6 behandelt de vraag welke markt- en kantoorkarakteristieken de kans op een afsplitsing voor een kantoor beïnvloeden. De variabelen die worden onderzocht worden in twee groepen ingedeeld, namelijk de push variabelen en de pull variabelen. De push variabelen representeren de variabelen die de mate van kansen voor de accountant(s) binnen het huidige kantoor weergeven. Pull variabelen representeren de variabelen die de mate van kansen voor de accountant(s) in de markt weergeven, en dus de mate van de kansen voor het opstarten van een nieuw kantoor (afsplitsing). Uit de analyses blijkt dat de push en de pull variabelen samen de beste verklaring geven voor de kans op een afsplitsing. Als de kansen binnen het huidige kantoor klein zijn en de kansen op de markt groot, dan is het meest waarschijnlijk dat accountants hun huidige kantoor verlaten en zelf een nieuw kantoor beginnen. Meer in het bijzonder blijkt dat de volgende push variabelen een positieve invloed hebben op de kans dat een accountant uit het kantoor wordt geduwd: de grootte van het kantoor (maar met een afnemend effect), de groei door acquisities van het kantoor, de betrokkenheid van het kantoor bij een fusie, en het opereren in de markt buiten de periode van vier jaar na de implementatie van de wet van 1970 om. De pull variabelen die een positieve invloed hebben op de kans dat een accountant in de markt wordt getrokken zijn: de dichtheid, oftewel het aantal kantoren in de markt (maar met een afnemend effect), een kleinere hoeveelheid uittredingen en het opereren binnen vier jaar na de implementatie van de wet van 1983 .

In het algemeen geldt dat de lange termijn dynamiek in de Nederlandse accountancy markt het meest verklaard wordt door de leeftijd van het individuele kantoor, de dichtheid in de markt en de grootte van het individuele kantoor. Als deze variabelen positief staan ten opzichte van de overlevingskansen van accountantskantoren, dan is tevens de kans op het hebben van een afsplitsing het grootst. Verder hebben alle processen, zoals ook al hierboven aangegeven, natuurlijk ook hun eigen verklarende variabelen. 



\section{CURRICULUM VitaE}

Vera Bröcheler was born on March the 6th, 1972 in Sittard (the Netherlands). She studied Economics and Business administration at Maastricht University, where she obtained her Master's degree (with distinction) in 1995. After that, she started as a Ph.D. at the Department of Organization Studies of Maastricht University. In april and may 1998, she was a visiting scholar at the Institute of Industrial Relations of the University of California, Berkeley. From May 1999, she became assistant professor at the same department as where she was a Ph.D. From September 1st, 1999, she has been working at the Dutch competition authority.

Vera Bröcheler werd geboren op 6 maart 1972 te Sittard. Ze studeerde Bedrijfseconomie aan de Universiteit Maastricht, waar zij in 1995 cum laude afstudeerde. Daarna trad zij als Assistent-in-Opleiding (AiO) in dienst bij de Sectie Organisatie van de Universiteit Maastricht. In april en mei 1998 verbleef zij als visiting student aan het Institute of Industrial Relations van de University of California, Berkeley. Voorts werkte zij vanaf mei 1999 als universitair docent bij dezelfde Sectie als waar zij AiO was. Sinds 1 september 1999 werkt zij bij de Nederlandse Mededingingsautoriteit. 

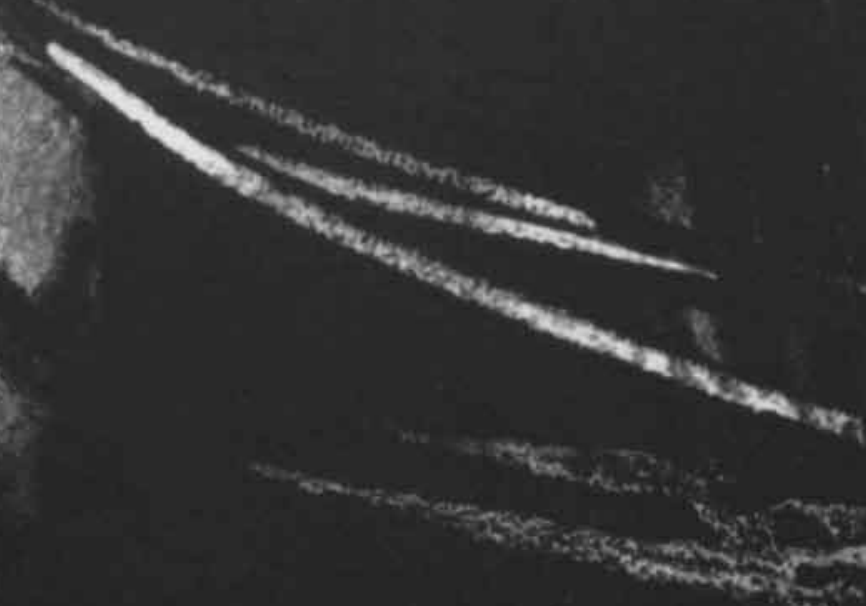

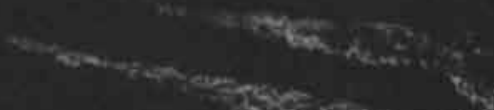

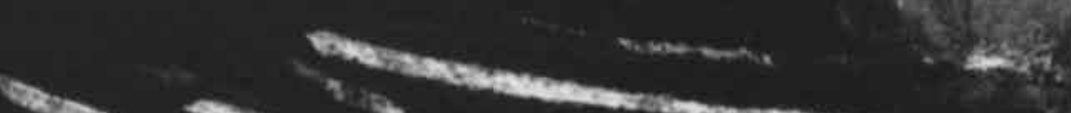

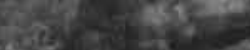
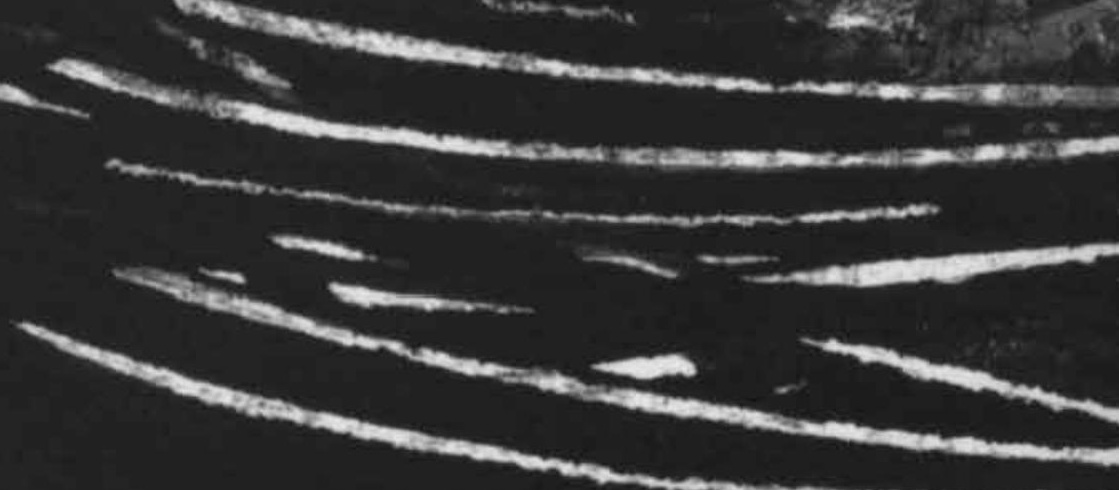

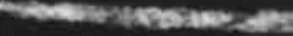
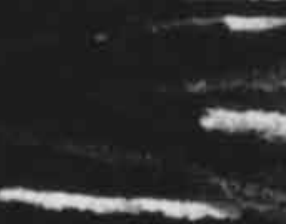

.
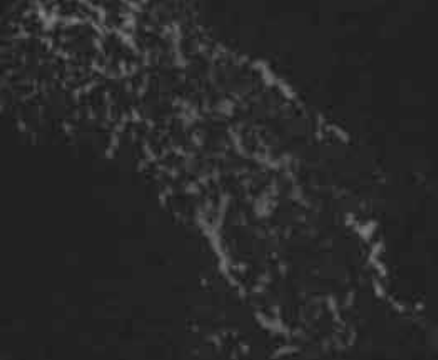

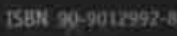

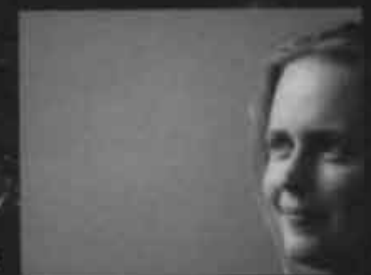

